\title{
Relatos míticos y prácticas rituales en Pachacamac
}

Récits mythiques et pratiques rituelles À Pachacamac

Myths and Ritual Practices at Pachacamac

\section{Peter Eeckhout}

\section{OpenEdition}

\section{Journals}

Edición electrónica

URL: http://journals.openedition.org/bifea/5786

DOI: $10.4000 /$ bifea.5786

ISSN: 2076-5827

\section{Editor}

Institut Français d'Études Andines

\section{Edición impresa}

Fecha de publicación: 1 abril 2004

Paginación: 1-54

ISSN: 0303-7495

\section{Referencia electrónica}

Peter Eeckhout, "Relatos míticos y prácticas rituales en Pachacamac », Bulletin de l'Institut français d'études andines [En línea], 33 (1) | 2004, Publicado el 08 abril 2004, consultado el 10 diciembre 2020. URL : http://journals.openedition.org/bifea/5786 ; DOI : https://doi.org/10.4000/bifea.5786

Les contenus du Bulletin de l'Institut français d'études andines sont mis à disposition selon les termes de la licence Creative Commons Attribution - Pas d'Utilisation Commerciale - Pas de Modification 4.0 International. 
Bull. Inst. fr. études andines

2004, 33 (1): 1-54

\section{RELATOS MÍTICOS Y PRÁCTICAS RITUALES EN PACHACAMAC}

Peter EECKHOUT

\section{Resumen}

En el marco del presente ensayo, propongo una síntesis crítica de las informaciones y los conocimientos actuales referentes al culto de Ychsma, importante divinidad prehispánica cuyo santuario se encontraba en el sitio monumental de Pachacamac, costa central del Perú. Este análisis se basa en fuentes etnohistóricas y etnográficas, así como en los nuevos datos arqueológicos recolectados durante las investigaciones llevadas a cabo hace poco en el sitio y su comarca. La etimología y el estudio de las fuentes escritas subrayan la especificidad costeña del dios y demuestran también que el culto y los mitos han sido manipulados por los incas. Una serie de prácticas rituales (sacrificos humanos y de animales, ofrendas diversas, romería, adivinación, culto a los ancestros) se examinan bajo la luz de los testimonios coloniales (principalmente las extirpaciones de idolatrías) así como de los hallazgos arqueológicos. Dicha confrontación sistemática proporciona un panorama de las costumbres cultuales mucho más completo que lo que ha sido propuesto a la fecha para la zona Lurín-Rímac.

Palabras claves: Pachacamac, religiones precolombinas, mitos, sacrificios, ofrendas, prácticas rituales.

\section{RÉCITS MYTHIQUES ET PRATIQUES RITUELLES À PACHACAMAC}

\section{Résumé}

Dans le cadre de cet essai, je propose une synthèse critique des informations et connaissances actuelles relatives au culte de Ychsma, importante divinité préhispanique dont le sanctuaire se trouvait dans l'enceinte du site monumental de Pachacamac, côte centrale du Pérou. Cette analyse fait appel aux sources ethnohistoriques et ethnographiques, mais aussi aux nouvelles données archéologiques récoltées lors des récentes recherches menées sur le site et sa région. L'étymologie et l'étude des sources écrites soulignent la spécificité côtière de la divinité, mais elles montrent également que le culte et les mythes ont été manipulés par les Incas. Une série de pratiques rituelles (sacrifices humains et d'animaux, offrandes diverses, pèlerinage, divination, culte aux ancêtres) sont examinées à la lumière conjuguée des comptes

"Universidad Libre de Bruselas, Facultad de Filosofía y Letras (CP 175), Av. F. Roosevelt, 50, B-1050 Bruselas. E-mail: peeckhou@ulb.ac.be 
rendus coloniaux (principalement des extirpations d'idôlatries) et des découvertes archéologiques. Cette confrontation systématique permet de brosser un tableau des coutumes cultuelles préhispaniques plus complet que tout ce qui a été proposé à ce jour pour la zone Lurín-Rímac.

Mots clés : Pachacamac, religions précolombiennes, mythes, sacrifices, offrandes, pratiques rituelles.

\title{
MYTHS AND RITUAL PRACTICES AT PACHACAMAC
}

\begin{abstract}
In this paper, I provide a critical synthesis of current information and knowledge related to the cult of Ychsma, an important deity whose sanctuary was established in the monumental precinct of Pachacamac, central coast of Peru. This analysis uses ethnohistoric and ethnographic records, as well as new archaeological data collected during research recently carried out at the site and surrounding area. Etymology and the study of written sources underlines the coastal characteristics of this deity. They also show that the cult and the myths were manipulated by the Inkas. A series of ritual practices (human and animal sacrifices, offerings, pilgrimage, divination, ancestor cults) are examined in the light of both colonial accounts (mainly extirpations of idolatries) and archaeological finds. Such a systematic comparison enables me to draw a more complete picture of prehispanic religious customs than anything previously proposed for the Lurín-Rímac area.
\end{abstract}

Key words: Pachacamac, Pre-Columbian Religions, Myths, Sacrifices, Offerings, Rituals Practices.

Pachacamac, sitio monumental entre los más famosos de la prehistoria andina se conoce tanto por el tamaño de sus ruinas como por la importancia de la divinidad que tenía allá su santuario. Creador, oráculo, maestro de los terremotos, taumaturgo y proveedor de bienaventuranzas, el gran Pachacamac tenía tanto renombre en la época Inca que los mismos emperadores se desplazaban para solicitarle consejos y asistencia. Venidos de todas partes del Imperio, hasta de Ecuador, gentíos de peregrinos se juntaban en el centro ceremonial, cuyo lujo y riqueza rivalizaban con los santuarios del Cuzco y del Titicaca. Esta prosperidad y fama harán de este sitio uno de las primeros blancos de los conquistadores, quienes lo invadirán y saquearán en enero y febrero de 1533, destrozando a su llegada el ídolo principal de la divinidad.

El culto y la importancia religiosa de Pachacamac en la época de la conquista se atestiguan en numerosas fuentes etnohistóricas (Calancha, 1975[1638]; Cieza de León, 1995[1551]; Cobo, 1964[1653]; 1990[1653]; Garcilaso de la Vega, 1991[1609]; H. Pizarro, 1872[1533]; P. Pizarro, 1978[1571]; Santa Cruz Pachacuti, 1879[1613]; Santillán; 1879[1551]; e.o.). Estudios científicos dedicados a la divinidad ya se encuentran en el siglo XIX (Rivero \& Tschudi, 1851). Varios de los más grandes 
andinistas tocaron el tema: Ühle (1903: 47-55) por supuesto, pero también Tello (1923a; 1923b;), Métraux (1949) o Rowe (1946). Desde los años 1970, la más importante contribución y los avances más destacados los debemos a María Rostworowski (1972; $1977 ; 1978 ; 1983 ; 1989 ; 1991 ; 1992 ; 1993 a ; 1999 a)$. Otros también se interesaron por el tema, pero según una perspectiva arqueológica (Bueno Mendoza, 1982; Jiménez Borja, 1985; 1992). Además, existen estudios específicos (Gisbert, 1993; Eeckhout, 1993; 1998a) así como ensayos generales donde la figura de Pachacamac se analiza (Demarest, 1981; Eeckhout, 1999a; Krickeberg, 1971; Pease, 1973; 1992; Malengreau, 1995; Rostworowski, 1999b; Urbano, 1981).

Mi ambición en el marco del presente ensayo es intentar tender un puente entre los registros escritos y materiales por lo que concierne las cuestiones religiosas y rituales en Pachacamac durante los periodos prehispánicos tardíos. Lo que sabemos de la divinidad principal y su culto nos fue transmitido por las fuentes etnohistóricas, las cuales documentan a veces - lo veremos - ciertas prácticas rituales. Haré el balance de esos relatos y testimonios, con el fin de poner en evidencia las características principales del dios, de sus elementos asociados, así como de las costumbres ceremoniales locales. En seguida presentaré una lista de las prácticas rituales — o consideradas como tales-observadas en el registro arqueológico de las excavaciones llevadas a cabo en el sitio y su zona de influencia directa. Veremos cómo estos dos conjuntos de datos (etnohistóricos y arqueológicos) se aclaran o se completan mutuamente.

\section{YCHSMA-PACHACAMAC: ETIMOLOGÍA E IDENTIDAD}

Se debe subrayar que Pachacamac es un término procedente del quechua - el idioma de los incas - y que al parecer la ciudad tenía otro nombre antes de la conquista efectuada por éstos:

“(...) y así el nombre de ese valle fue cambiado de Irma en Pachacamac” (Santillán, 1879[1551]: 33).

"El nombre deste demonio quería dezir hacedor del mundo. Porque camac quiere dezir hazedor; y pacha mundo" (Cieza de León, 1995[1551], I, cap. 72; Acosta, 1979[1589]: 238; Calancha, 1975[1638] Libro I, cap. XIX; Cobo, 1964[1653]: Libro XIII, Cap. II; Santillán, 1879[1551]: 32; Velasco, 1840[s.f.]: 99).

El hecho de que el nombre del valle también fue cambiado es significativo: Irma (1) se ha vuelto Lurín, es decir Hurin, término quechua que designa "lo de abajo", cuya importancia simbólica aparecerá en el curso de este análisis. Rostworowski (1992: 78-79; 1999a) precisa que la pronunciación exacta es Ychsma, tal como se indica en la Visita de Andrade en 1573. Es la razón por la cual usaré este término a lo largo del presente trabajo, excepto para las citas donde la ortografía de cada autor será respetada.

Tomando en cuenta este cambio de nombre, es razonable suponer que las leyendas referidas a Pachacamac concernían inicialmente a Ychsma, y que con el correr del tiempo fueron mezclándose con otros mitos relacionados con la figura del dios creador, de los cuales se encuentran numerosos ejemplos a lo largo de los Andes. Pero es muy difícil definir qué de autóctono y qué de importación hay en lo que concierne a Ychsma Pachacamac. Rowe (1946: 293) señala:

(1) Cuyas diversas pronunciaciones y ortografías son Yxma, Ichma, Ychma e Ychsma. 
“(...) a pesar de que las prácticas religiosas de esas dos regiones (el Cuzco y la costa de los alrededores de Lima) son similares, difieren en los detalles y en los objetos del culto. Es posible que numerosas de esas similitudes sean el resultado de la influencia Inca sobre las provincias del Imperio".

Sin embargo, ¿podemos postular la "incaización” de las tradiciones religiosas en la costa y ver en la figura de Pachacamac una simple réplica del Viracocha andino, a la que solamente se le habría cambiado el nombre? Sobre este delicado punto, los autores — tanto los antiguos como los modernos- están divididos. Sarmiento de Gamboa (ca.1907[1572]: 28) afirmaba ya en el siglo XVI que Viracocha es el creador de todas las cosas; “(...) por eso él fue llamado Pachayachachi, el instrutor del universo”. Molina de Cuzco (1943[1552]:13) está conforme. Siguiéndoles, no se puede llamar Pachacamac al dios creador. Tampoco según Acosta (1979[1589]: 301), quien explica que los indios

“(...) tenían un conocimiento del Padre Supremo y autor de todas las cosas, que los del Perú llamaban Viracocha y al cual daban títulos de gran excelencia como Pachacamac, Pachayachachic que es el creador del cielo y la tierra y Vsapu (2), que quiere decir admirable, y otros nombres".

Identificaciones similares entre Pachacamac y Viracocha como dios creador de los incas han sido planteadas por Cieza de León (1995[1551], lib. 1, cap. LXXII) y Garcilaso de la Vega (1991[1609], lib. 2, cap. XXVII).

¿Se debe entender a Pachacamac como un simple atributo, una faceta entre varias del gran Viracocha? Aparentemente es lo que cree Ühle (1903: 48) quien, sobre la base del estudio iconográfico de los atributos de la imagen del dios que preside la famosa Puerta del Sol de Tiahuanaco (Bolivia), sostiene que

"(...) el santuario de Pachacamac [es] derivado del culto del dios creador en las tierras altas, dios que se ve sobre el relieve (...) y que se llama Viracocha, Tonapa, o Tarapaca".

En su análisis de la figura de Viracocha, Markham (en Sarmiento, 1907[ca. 1572]: 28, nota 1) presenta también Pachacamac y Pachayachachic como atributos de la divinidad. Finalmente, según Krickeberg (1971: 245), durante la conquista inca, el dios costeño fue incorporado al panteón quechua e identificado con el dios Viracocha. Demarest (1981: 53) lo aprueba precisando, sin embargo, que Pachacamac, Viracocha, pero también Koniraya y Chincha Camac (versión meridional del creador costeño) proceden de un mismo principio, históricamente anterior (3). Quizá sea apresurado

(2) También ortografiado "Sapay".

(3) Urbano $(1981 ; 1986 ; 1993)$ propone una interpretación trifuncional de los mitos andinos. En esta óptica, Viracocha o una divinidad homóloga está considerado como la síntesis de una pareja de elementos opuestos. Dicha interpretación se acerca a la de los sacerdotes católicos que encierran los actores míticos y religiosos autóctonos dentro de un esquema inspirado por la Trinidad bíblica y coincide, incluso, con la teoría dumeziliana de las tres funciones, desarrollada en base a material indo-europeo. Las propuestas de Urbano parecen, en este campo, algo excesivas, pero su impacto en la disciplina no se puede ignorar. Sin entrar en los detalles del debate, las líneas que siguen ilustran los reparos que las ideas de Urbano pueden suscitar: "Aparte del hecho que la trifuncionalidad parece introducir bajo la forma de una síntesis superior una realidad exterior a sus componentes originales andinos, la imposición de una estructuración como ésta al material mitológico andino parece ignorar la irreductibilidad aparente de los elementos en presencia, definidos 
plantear la existencia de una fusión entre ambas divinidades en el pensamiento inca. De haber sido el caso, ¿no habrían rebautizado los incas Ychsma con el nombre de Viracocha antes que con el de Pachacamac? De acuerdo con Rowe (1946: 293), quien admite la existencia de cierta similitud entre ambas divinidades, “(...) esa identificación nunca fue completa, porque Pachacamac nunca es llamado Viracocha”. Por otro lado, subrayamos que tampoco Favre (1972: 24) es de la misma opinión de Krickeberg. Él dice que "(...) Pachacamac (...) fue integrado al panteón oficial del Estado Inca”. Un cronista - Cobo (1964[1653], L. 13, cap. 2) — ofrece argumentos en este sentido al distinguir media docena de dioses creadores diferentes de acuerdo con las regiones, entre los cuales figuran Pachacamac “(...) en los habitantes de los llanos y de las tierras marítimas" y Viracocha, cuya creación empieza con un diluvio. ¿Qué debemos concluir de todo esto? ¿Una sola divinidad con varios nombres y atributos diferentes o dos dioses distintos con características similares?

El problema nos parece mal planteado desde el punto de partida, porque todos los autores hablan de Pachacamac — nombre quechua, cultura Inca—, mientras que el dios se llamaba Ychsma — nombre yunga, cultura costeña- Es obvio que, de una forma u otra, los incas quisieron favorecer el acercamiento a su propia teología. Al identificar completamente al dios costeño con Viracocha, se ingresa de lleno en la lógica Inca y no se toca el fondo del problema.

Probablemente, un examen cuidadoso del mito principal concerniente a YchsmaPachacamac pueda ayudarnos a esclarecer los rasgos específicos del dios, así como sus diferencias y similitudes con Viracocha.

\section{LOS MITOS DE YCHSMA-PACHACAMAC}

Al inicio de los tiempos, existió Con, hijo del Sol, procedente del norte y creador de los primeros hombres (4). Por alguna razón mal definida, Con se enfureció y privó a los seres humanos de las ventajas que les había concedido en un primer momento. Vino entonces Pachacamac y expulsó a Con. El también era hijo del Sol (y de la Luna). Transformó en gatos negros a los hombres que Con había creado y formó nuevos individuos, semejantes a los que viven hoy en día, colmándolos de bienes con su generosidad. Ellos, agradecidos, lo tomaron como dios y lo adoraron. Así termina López de Gómara (1965[1552], cap. XXII: 234) su transcripción de la historia de la creación de la humanidad, y agrega que fueron esos "primeros hombres" quienes edificaron el templo de Pachacamac y dieron su nombre a toda la región (5).

esencialmente en el marco de una relación de equilibrio y no de fusión. La estructura triádica en realidad no aparece mucho en la mitología andina (...). Estamos en presencia, sea, de una divinidad masculina con componentes dobles, sea de una divinidad femenina con un niño masculino, sea una pareja conformada por un hombre y una mujer con niños de sexo diferente; cada uno de los elementos a su vez asociado con un elemento natural o una actividad cultural, a su vez competiendo a pares. El elemento intermedio que aparece en ciertos casos sólo existe para separar dos otros términos fundamentales pero de ninguna manera como una síntesis" (Malengreau, 1995: 114).

(4) Sobre Con, ver López de Gómara (1965[1552]: 233 \& ss), analizado por Krickeberg (1971: 170, 244). Ver también Gisbert (1993) y Rostworowski (1993a).

(5) Rivero \& Tschudi (1851: 143-144) avanzan que es por causa del vicio y del crímen en que los hombres cayeron, que Con les castigó transformándoles en gatos negros y a la tierra en un desierto. 
Calancha aporta informaciones complementarias a propósito de la deidad. Explica que los hombres creados por Pachacamac se morían de hambre y se vieron obligados a nutrirse de raíces y hierbas para continuar sobreviviendo. Se lamentaron de ello ante el Sol, quien - fecundando a una mujer con sus rayos- concibió un hijo para socorrerlos. Celoso por el hecho de que los seres humanos acudieran al Sol antes que a él, Pachacamac mató y desmembró a su medio hermano. De sus dientes nació el maíz; de sus huesos y costillas, las diversas especies de yuca; de su carne, las demás plantas útiles y las frutas. Desde entonces, los hombres no conocieron nunca más el hambre ni la necesidad. A Pachacamac se le deben la salud y la abundancia, porque él continúa dotando a la tierra de fertilidad (Calancha 1975[1638], lib. I, cap. 22).

Remarcamos así la insistencia tanto en la prodigalidad de Pachacamac como en la fertilidad que éste engendra a raíz de la matanza. Un paralelo interesante puede observarse entre los relatos de Gómara y Calancha: en ambos relatos la abundancia, la fertilidad y la vida ideal son consecuencias de la desaparición de un ser sobrehumano gracias a la intervención de Pachacamac.

Pero regresemos a Calancha porque la historia no se detiene en este punto. La madre del semidios asesinado, desesperada, acude al Sol, quien por segunda vez le da un hijo, Vichama (6). Aprovechando la ausencia de Vichama, Pachacamac mata a su madre y la corta en pedazos, con los que da de comer a las aves. Posteriormente, esconde sus cabellos y sus huesos al borde del mar. De ellos nacen las primeras parejas, los curacas y los caciques.

A su retorno, Vichama conoce la triste noticia y resucita a su madre. Decide vengarse y matar a Pachacamac. Este se arroja al mar, en el lugar donde se encuentra el santuario dedicado a él.

Vichama continúa furioso y acusa a los hombres de ser cómplices de la matanza de su madre. A manera de castigo, pide y obtiene del Sol la petrificación de los seres humanos. Posteriormente — también a raíz de un pedido de Vichama- el Sol crea una nueva humanidad a partir de tres huevos: uno de oro, uno de plata y otro de cobre. Es interesante resaltar que todavía en Calancha, los habitantes de la costa y los indios que viven en Carabayllo — cien leguas al norte de Lima—, los de Pachacamac — cinco leguas al sur - y los pueblos que se extienden a lo largo de la costa hasta Arica, atribuyen a Pachacamac la creación de los hombres a partir de cuatro estrellas, dos machos y dos hembras (resumen de Calancha 1975[1638], lib. I, cap. 22).

Según Duviols (1983), Calancha se inspira de una versión del mito recogida en el año 1617 en La Barranca por el padre Teruel. La versión de Teruel (Duviols, 1983: 389-390; Polia, 1999: 393-394) es más corta pero instructiva, ya que está menos alejada del original indígena. La petrificación de los hombres es presentada como el acto de Vichama solamente, quien "(...) a los curacas principales convirtio en piedras que fuessen guacas adoradas como dioses y a los yndios plebeios en piedras ordinarias" (Duviols, 1983: 389-390; Polia, 1999: 393-394). La creación que sigue no se atribuye

En su versión, se presenta a Pachacamac como el hijo de Kon, quien resucita a los hombres y recrea todo lo que su padre había destruido. Estos autores no proporcionan ninguna referencia respecto a su fuente.

(6) Rostworowski (1983: 44) habla de resurección, alegando el hecho de que es a partir del ombligo del niño desmembrado que el Sol crea a Vichama. 
a ningún ser particular, sino que resulta simplemente del producto de tres huevos (siendo uno de oro y otro de plata) que "caieron del cielo" ( Duviols, 1983: 389-390; Polia, 1999: 393-394) (7).

Inicialmente el rol de dios creador fue atribuido a Con. Es interesante señalar que, alrededor del año 1608, Avila nos habla de Coniraya Viracocha a través de numerosos relatos breves en los que el personaje aparece justamente como dios creador (por ejemplo, Avila 1980[1608?], cap. 15). El hecho de que la raíz Con (8) aparezca tan estrechamente asociada a la vez a Viracocha y al antiguo nombre de Pachacamac es llamativo.

En una de sus primeras aventuras, Coniraya Viracocha, vestido de hombre pobre, fecunda a una virgen - la bella Cauillaca - por medio de una fruta que esta come. Cauillaca quiere conocer el nombre del padre de su hijo y con este fin reúne a todos los dioses - huacas — de la Tierra (9). Finalmente, comprende que el responsable de su estado es el mendigo feo y sucio. Avergonzada y desesperada, se tira al mar, a la altura del templo de Pachacamac, donde, junto con su hijo, se transforma en un conjunto de rocas que todavía pueden ser observadas hoy en día (Avila, 1980[1608?]: cap. 2) (10). Finalmente, Villar Córdova (1933) relata un mito muy interesante, recopilado a inicios del siglo pasado en la provincia de Canta (alto Chillón), el cual resumiré aquí muy brevemente. Pachamama se presenta como la esposa viuda de Pachacamac después de que se había tirado al mar. De él tiene dos hijos gemelos de sexo diferente, los willkas ("sol" en aymara; o "recién nacido" en quechua). Los dos huérfanos y su madre vagan de noche, perdidos, y son acogidos por el demonio caníbal Wa-Kon. Él intenta seducir a Pachamama, y frente a su rechazo la mata y se la come (11). Los gemelos willkas huyen y les acoge un zorrillo que les alimenta con su propia sangre y les ayuda a vengarse de Wa-Kon haciendo caer al demonio en una trampa mortal. Luego suben los willkas al cielo gracias a su padre que les esperaba allí. La hija se transforma en luna y el hijo en sol; Pachamama resucita y es recompensada por su fidelidad a Pachacamac que le confiere la facultad generadora.

Cuando uno se aproxima un poco más a los episodios significativos de cada uno de estos mitos, se observa con prontitud que numerosas preguntas pueden ser despejadas. Al parecer, bajo apariencias diferentes, sólo habría dos historias. Estas, a las que llamaremos A y B, se presentan a continuación:

(7) La última creación a partir de huevos de diferentes calidades que justifican míticamente la existencia de clases sociales jerarquizadas es un tema que se encuentra igualmente en el Cuzco (Gisbert, 1993: 185; Pease, 1973: 37) y la zona de Huacho y Vegueta en el norte de la costa central (Arriaga, 1920[1621]: 69). Polia (1999: 98, 385) remarca que en ciertas versiones no se trata de tres huveos sino de tres huesos. Este detalle le da a los osamientos una importancia simbólica específica que desarrollé en otro texto (Eeckhout, 1993: 143).

(8) De k'oni: calor solar (Krickeberg, 1971: 247), pero también el adjetivo q'oni: caliente, tibio (Lara, 1978: 196).

(9) El término huaca debe entenderse aquí como "dios local", según el traductor de Avila.

(10) Según Molina (1943[1552]: 6-7) estas rocas son hombres petrificados por el Creador Tecsi Viracocha por causa de su desobediencia.

(11) Esta parte del relato es muy semejante al mito de Koniraya Viracocha y Urpi Wachak relatado por Avila (1980[1608?]: cap. II). 


\section{Secuencia A (Cuadro 1)}

Episodio 1: un ser sobrehumano creador es culpable de una falta.

Episodio 2: el ser sobrehumano destruye a la humanidad.

Episodio 3: el ser sobrehumano crea una nueva humanidad.

\section{Cuadro 1 - Los mitos de Pachacamac, secuencia A.}

\begin{tabular}{|llll|}
\hline Secuencia A & $\begin{array}{l}\text { López de Gomára } \\
\text { 1965: 234 }\end{array}$ & $\begin{array}{l}\text { Teruel } \\
\text { Duviols, 1983 }\end{array}$ & Calancha \\
& Episodio 1 & Pachacamac rechaza & Vichama rechaza a 22 \\
& a Con & Vichama rechaza a \\
Episodio 2 & Pachacamac cambia & Vichama petrifica a & Vichama, gracias al Sol, \\
& los hombres en & los hombres & petrifica a los hombres \\
& gatos negros & & \\
Episodio 3 & Pachacamac crea & Tres huevos engendran & Vichama y el Sol ( ?) \\
& nuevos hombres & una nueva humanidad & crean una nueva \\
& & & humanidad
\end{tabular}

\section{Secuencia B (Cuadro 2)}

Episodio 1: una mujer es fecundada mágicamente por el dios supremo.

Episodio 2: la mujer da a luz un ser sobrehumano.

Episodio 3: la madre y/o su hijo mueren.

Episodio 4: creación.

Cuadro 2 - Los mitos de Pachacamac, secuencia B.

\begin{tabular}{|lllll|}
\hline Secuencia B Calancha & Calancha & $\begin{array}{c}\text { Avila 1980[1608?] } \\
\text { cap. II }\end{array}$ & Villar 1933 \\
\hline Episodio 1 & $\begin{array}{c}\text { Mujer fecundada } \\
\text { por el Sol }\end{array}$ & $\begin{array}{l}\text { Mujer fecundada } \\
\text { por el Sol }\end{array}$ & $\begin{array}{l}\text { Cauillaca } \\
\text { fecundada por }\end{array}$ & fecundada por \\
& & Koniraya Viracocha & Pachacamac \\
Episodio 2 & Nacimiento & Renacimiento del & Nacimiento de & Nacimiento de \\
& mágico de un & hijo, Vichama & Pachacamac & los willkas \\
hijo luego de & & & \\
4 días & & & \\
\hline
\end{tabular}




\begin{tabular}{|lllll|}
\hline Episodio 3 & $\begin{array}{l}\text { Asesinato del hijo } \\
(\text { ¿Vichama ?) por } \\
\text { Pachacamac }\end{array}$ & $\begin{array}{l}\text { Asesinato de la } \\
\text { madre por } \\
\text { Pachacamac }\end{array}$ & $\begin{array}{l}\text { Suicidio de la } \\
\text { madre y del } \\
\text { hijo perseguido } \\
\text { por Koniraya }\end{array}$ & $\begin{array}{l}\text { Asesinato de la } \\
\text { Pachamama }\end{array}$ \\
Episodio 4 & $\begin{array}{l}\text { Cadáver } \\
\text { proporciona la } \\
\text { abundancia }\end{array}$ & $\begin{array}{l}\text { Cadáver } \\
\text { proporciona } \\
\text { el orden social }\end{array}$ & $\begin{array}{l}\text { Cadáveres } \\
\text { marcan el } \\
\text { Centro Sagrado }\end{array}$ & $\begin{array}{l}\text { Los willkas } \\
\text { se vuelven } \\
\text { Sol y Luna }\end{array}$ \\
\hline
\end{tabular}

Por otro lado, ciertos indicios son vínculos suplementarios que permiten tender puentes entre las diferentes versiones. Por ejemplo, la desaparición del ser sobrehumano en el mar, se encuentra en Avila (Cauillaca y su hijo perseguidos por Koniraya Viracocha se arrojan al océano) y en Calancha (Pachacamac perseguido por Vichama, desaparece en el mar). La petrificación, tema andino recurrente, está presente al final del mito en Teruel-Calancha (Vichama, solo o con la ayuda del Sol, petrifica a los hombres) y al final del mito en Avila (Cauillaca y su hijo se transforman en rocas) (12). Pero más allá de la demostración formal, de la puesta en evidencia de la estructura, el análisis esclarece el fondo de los mitos, es decir, su sentido, su significado, su alcance. En efecto, el mensaje que deja ver es nítido: la vida y la creación están ligadas a la muerte y a la destrucción; unas engendran las otras, es decir la muerte y la destrucción constituyen las bases indispensables para que la vida y la creación puedan realizarse. Esta relación estrecha entre muerte y vida se expresa en muchos otros contextos míticos y rituales andinos, como por ejemplo los monolitos huancas a los cuales ya se aludió más arriba ( $c f$. nota 12). Los mitos de Ychsma recuerdan y subrayan que este vínculo indefectible asegura la cohesión y la perpetuación del conjunto del universo (Polia, 1999: 105). Expresan asimismo, de manera metafórica, la base de las relaciones entre hombres y dioses, relaciones en las cuales el don (la ofrenda) y el sacrifico (la muerte) constituyen los elementos indispensables para el bienestar (fertilidad) y la vida (fecundidad).

\section{FIGURAS Y ESTRUCTURAS}

Como se puede ver, los mitos relacionados con la personalidad de YchsmaPachacamac se confunden con los mitos de creación registrados en la costa. Dichos mitos se organizan de forma repetitiva: los personajes y circunstancias cambian en algo según las versiones, pero el papel de cada uno y la trama de la historia son los mismos. Es importante constatar la semejanza de los nombres patronímicos de los principales interventores (Ychsma, Vichama, Iraya). Por otro lado el sol parece intervenir en los mitos de creación costeños, no tanto como un actor de pleno

(12) Esto recuerda a los monolitos huancas, dobles minerales de los cadáveres de los ancestros fundadores a quienes se le rendían culto como garantes de la fertilidad y nexos entre el inframundo, la tierra y el cielo (Duviols, 1979). Siguiendo a Duviols (1979: 13), la tradición no explica el fenómeno de "litificación", se contenta en afirmarlo. "La petrificación es perenización, sacralización", y no muerte (Duviols, 1973: 164). 
derecho, sino más bien como elemento exterior, cuya importancia varía según las versiones y episodios. Sin embargo, el análisis más corriente (Gisbert, 1993; Malengreau, 1995; Rostoworowski, 1977; 1992; e.o.) presenta los mitos de Ychsma-Pachacamac como una metáfora de la alternancia entre el día y la noche, de la asociación y disociación del sol y de la Tierra, tal como lo ilustra el esquema siguiente (a partir de Malengreau, 1995: 112):

\title{
Pachacamac (noche/muerte/ruptura)
}

\author{
Pachamama (Tierra)
}

$\operatorname{Inti}(\mathrm{sol})$

\section{Vichama (día/vida/unión)}

Dicha interpretación tiene a menos la especificidad cultural costeña del periodo Intermedio Tardío. Por su carácter sumamente general, recuerda a la corriente naturalista de moda en el siglo XIX ( $c f$. Rivero \& Tschudi, 1851: 144 \& ss.; Ühle, 1903: 52-53). Más bien, ¿no se podría ver en estas intervenciones del sol la huella de la influencia Inca? Se podría efectivamente pensar que el sol se incorporó a mitos que antes funcionaban sin él, tal como lo indica la comparación de las versiones de Calancha y Teruel. Pease (1973: 39-50) anota al respecto que el sol sólo está presente en los mitos de creación Incas relatados por Garcilaso de la Vega. El autor lo considera como un añadido tardío debido a la nobleza Inca sin que tuviera tiempo de estar verdaderamente integrado a la tradición popular; Pachacamac, al igual que Viracocha, corresponde al prototipo del dios creador, siendo luego ambos "solarizados" (Garcilaso de la Vega 1991[1609]). Demarest (1981: 44-49) piensa también que el aspecto solar de Viracocha fue favorecido de forma creciente por la elite imperial en el transcurso del tiempo, con el fin de poner en valor la ascendencia divina de los dirigentes. Al respecto, Zuidema (1962: 165) avanza que fue el Sol quien creó a los líderes Incas, mientras Viracocha creó al pueblo. Una cita de Avila nos informa respecto a las relaciones entre Inti y Pachacamac:

"Se dice que cuando los ingas estaban en las tierras altas, celebraban el culto del sol al que adoraban en su santuario de Titicaca diciendo: 'es éste quien nos ha animado a nosotros los ingas'. Cuando estaban en las tierras bajas, adoraban a Pachacamac, diciendo: 'es éste quien nos ha animado a nosostros los ingas' (...) los ingas creían que los límites de la tierra se encontraban en Titicaca y, por la otra parte del mar, en las tierras de Pachacamac; mas allá no había más nada. Era quizá a causa de esta creencia que adoraban a estos dos huacas más que a todas las demás y levantaron una imagen del sol en las proximidades de Pachacamac 'de abajo'. Y hasta hoy se llama ese lugar Punchaucancha” (Avila in Taylor, 1987: cap. XXII).

Según Demarest (1981), Punchao representa el sol joven, o sea, el día. Pachacamac sería pues el Creador hurin, de abajo, y Viracocha (asimilado al sol), el hanan de arriba. Pease (1973: 52) y Demarest (1981: 53) piensan asimismo que Pachacamac sería el dios creador costeño y Viracocha el dios creador serrano. Dicha división bipartita arriba/abajo, fundamental en todo el pensamiento andino, tendría así una ilustración suplementaria. Otras se encuentran en las diferentes figuras asociadas con Pachacamac, donde la oposición con las tierras altas también se marca de manera profunda. La zorra, por ejemplo, animal 
favorito del gran dios (Alborñoz, 1967: 34; Calancha, 1975[1638]: 925; Cieza de León, 1995[1551]: I, cap. L; Espejo Nuñez, 1941: 69-71; Eeckhout, 1998a), se consideraba astuta y brava entre los habitantes de los llanos, mientras los serranos hacen hincapié en su vanidad y suficiencia. El animal es claramente despreciado:

"Aunque andes a distancia, los hombres llenos de odio, te tratarán de zorro malvado y desgraciado; cuando te maten, te botarán a ti y tu piel como a algo sin valor" (Taylor, 1987, cap. 2: 65).

Remarcamos que en el curso del mismo periplo, Cuniraya bendice a los animales que le dan ánimo (el puma, el cóndor, el halcón) y maldice los que le desalientan (la zorra, el loro, el zorrillo) (Taylor, 1987, cap. 2: 63-65). Venerada por los costeños a causa de su astucia, despreciada por los serranos a causa de su pretensión, la zorra aparece como un animal clave, símbolo del antagonismo de los dos pueblos: los de abajo, los yungas, ligados a la luna, a la tierra, a la noche; y los de arriba, los yauyos, ligados al sol, al fuego, al día, simbolizados por los animales helíacos que son el cóndor y el puma. Avila (in Taylor, 1987) menciona a Pachacamac "de abajo", dios principal de los yungas, y a Pariacaca "de arriba", dios principal de los yauyos. Pease (1973: 34) también opone Viracocha (dios celestial y serrano) a Pachacamac (terrestre y costeño). A semejanza de Rostworowski (1992: 91), creo que aquí se encuentra la indicación de un concepto dualista de la sociedad y del espacio (Cuadro 3). Sin embargo no hay que engañarse: dicha división no refleja un estado de hechos establecidos, sino más bien una dinámica de conflicto. La división bipartita de la humanidad es reconocida pero la repartición territorial es permanentemente impugnada, tal como lo atestiguan los numerosos indicios del antagonismo yauyos-yunga en las fuentes etnohistóricas (Taylor, 1987; Rostoworowski, 1978: 43; 1992: 91) y en el registro arqueológico (Eeckhout, 1999a: 453-454; Feltham, 1983; 1984; Paredes, 1990:192; Sánchez Borja, 2000). El control de las fuentes de agua y de los canales, elementos vitales para la ecología y la supervivencia de los pueblos andinos precolombinos, especialmente en la costa, está en el centro de las luchas incesantes que oponen a unos y otros con el correr de las generaciones. A nivel mítico, el agua y el cielo tienen un papel ambiguo, a la vez unión y frontera, lugares de deseo y de muerte. La costa conforma el límite del mar, como las montañas se encuentran al límite del cielo. El sol es alto en estas latitudes, casi vertical, mucho más alto que la luna. Una geo-cosmología se forma donde las etnias encuentran su sitio, integradas a los elementos naturales. El combate secular de los yungas costeños frente a los yauyos serranos se inscribe desde siempre en el paisaje, hasta en el cosmos ( $c f$. Trimborn, 1953; Eeckhout, 1993; 1998a; 1999a: 383-398). 
Cuadro 3 - Oposiciones estructurales yunga-yauyos.

\begin{tabular}{|c|c|c|}
\hline Costa & & Sierra \\
\hline Yunga & & Yauyos \\
\hline Tierra & Agua/Cielo & Fuego solar \\
\hline Luna & & Sol \\
\hline Femenino & & Masculino \\
\hline Noche & & Día \\
\hline Zorra y Peces & Aves & Felino y Condor \\
\hline Hurin (Abajo) & & Hanan (Arriba) \\
\hline Ychsma-Pachacamac/ & & Pariacaca/ \\
\hline Huallallo Caruincho & & Cuniraya Viracocha \\
\hline
\end{tabular}

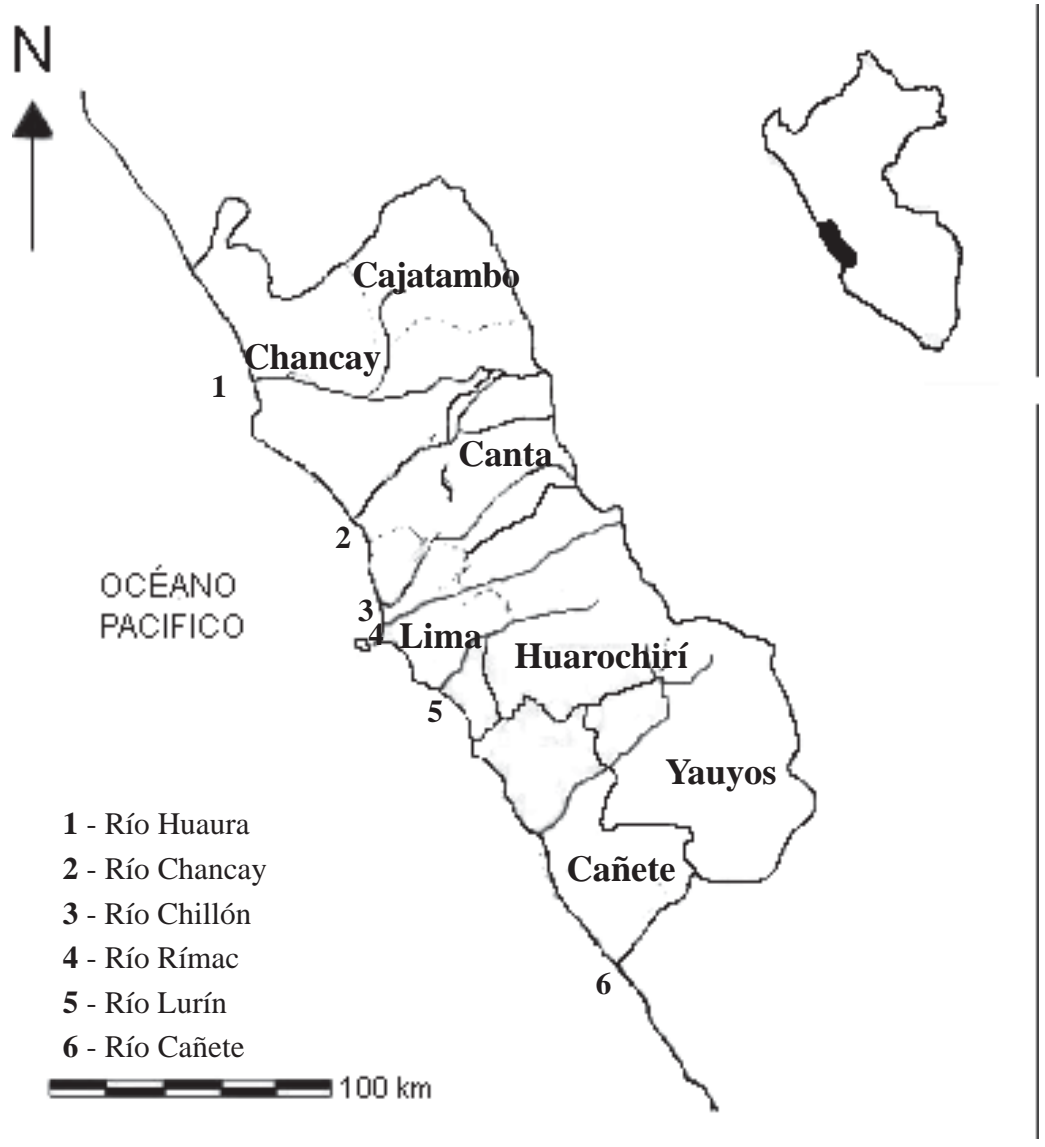

Fig. 1 - Mapa del área de estudio. 


\section{LAS PRÁCTICAS RITUALES}

Resultaría erróneo creer que las prácticas descritas por los cronistas de los siglos XVI y XVII fueron todas observadas de igual manera y para los mismos motivos en el conjunto de los Andes Centrales. Sería a la vez negar la diversidad cultural de las sociedades andinas y los cambios y transformaciones de todo tipo que experimentaron a lo largo de su desarrollo. Es por eso que me interesé aquí por las fuentes que relatan las "idolatrías" en el mismo Pachacamac y el área cercana, es decir, la costa central del Perú y la llanura andina directamente adyacente. Tales menciones específicas se encuentran en las crónicas de carácter general que tratan de todo el Perú (por ejemplo Alborñoz, Garcilaso de la Vega, Cobo, Cieza de León y otros) así como en relatos de las visitas realizadas en la zona de estudio (Fig. 1), sea Arriaga (1999[1621]), Avila (1980[1608?]), Duviols (1983), Hernández Príncipe (1919[1622]) y Polia (1999). Además de esto, creo que se debe repetir que las fuentes etnohistóricas atestiguan, por naturaleza, prácticas en uso durante las generaciones que siguieron a la conquista, y por esto más o menos alejadas en el tiempo de las prácticas prehispánicas; por más que los restos materiales de dichas prácticas puedan ser comparables, hasta idénticos, resulta sumamente difícil saber en qué medida su sentido, su justificación en la época colonial, corresponde al sentido y las motivaciones de la época Inca y pre-Inca. En efecto, son los mismos restos materiales los que nos servirán de guías y de puntos de referencia, pues constituyen por supuesto la principal base de datos para los periodos prehispánicos. Así pues, he llevado a cabo una selección entre los rituales descritos por los cronistas, privilegiando los susceptibles de dejar alguna huella en el registro arqueológico. Sólo así puede tener sentido el cotejo de datos.

\section{1. Sacrificios}

\section{1. 1. Sacrificios humanos}

“(...) y cuando hacían los sacrificios delante de la multitud del pueblo, iban los rostros hacia las puertas del templo y las espaldas a la figura del ídolo, llevando los ojos bajos y llenos de gran temblor (...)" (Cieza de León, 1995[1551]: cap. XLII).

Pachacamac parecía gozar de una reputación tan temible como extendida. Temible y sanguinaria porque, al parecer, se hicieron en su honor "numerosos sacrificios de animales y de sangre humana de personas que mataban" (Cieza de León, 1995[1551]: cap. XLII.) Cobo (1964[1653], L.13, cap. 36), inspirándose directamente en Cieza de León, confirma la existencia de sacrificios y precisa que tales prácticas solamente se producían en casos graves y excepcionales "(...) como cuando se sospechaba que alguna provincia quería rebelarse o que se preparaba una traición contra el Inca, y que eso no se podía verificar por testigos, torturas, o de otra manera". Cobo agrega, líneas después, que en estos casos se sacrificaban niños, a los que se enterraban vivos (Cobo 1964[1653], L.13, cap. 36), lo que podría confirmar el aspecto terrestre de Pachacamac. Santillán (1879[1551]: 32) señala que eran ofrecidas al dios chicas jóvenes, enterrándolas vivas.

"The most valuable sacrifice was of human beings, who were offered to the most important divinities and huacas on the most solemn occasions, such as pestilence, famine, and war reverses, at the coronation of a new Emperor (when 200 children were sacrificed), when the Emperor went to war in person, or when he was sick (...)" (Rowe, 1946: 305-306). 
Guamán Poma (1989[1613]: 265) indica que los sacrificios de niños en honor a Pachacamac se llevaban a cabo regularmente siguiendo el calendario ritual inca, un hecho confirmado por un nativo de la zona, el informador de Avila:

"Todos los años le ofrecían un capac hucha (13) [sacrificándole] gente [de todas las provincias] del Tahuantinsuyo, mujeres y hombres. Cuando llegaban a Pachacamac, enterraban vivas [a las víctimas de] ese capac hucha diciendo: 'helos aquí; te los ofrezco, padre.' De la misma manera, [le ofrecían] oro y plata y no dejaban [de sacrificarle] llamas y de hacerle ofrendas de bebida y comida en la época de la luna llena" (14) (Avila in Taylor, 1987, cap. 22: 331).

Para Velasco de Tord (1978: 194), los sacrificios humanos en el incanato se hicieron por varios motivos, todos relacionados con la luna. Las fiestas que se daban en Pachacamac se acompañaban con música y se celebraban especialmente en las noches de luna llena (Rostworowski, 1992: 101). En otro registro, se señalan a inicios del siglo XVII casos de sacrificios de chicas jóvenes destinadas a acompañar a los curacas en la muerte; eran arrojadas al vacío desde cierta altura (Polia, 1999: 296). Desafortunadamente, el documento no precisa qué destino se reservaba a sus restos mortales. El sacrificio de bebés también se practicaba con el fin de favorecer las cosechas (Polia, 1999: 449-450). Se les enterraba en el mismo sitio, es decir, en el campo (Polia, 1999: 449-450).

¿Cómo identificar un sacrificio humano en contexto arqueológico? ¿Cómo diferenciarlo de una sepultura clásica? Esas cuestiones esenciales han sido tocadas y discutidas por varios autores (Fleming, 1983; Lyon, 1995; Verano, 1995; 2001). En ciertos casos, la índole y calidad de los datos de campo dejan poca duda (Bourget, 1997; 1998; 2001a; Bourget \& Millaire, 2000; Cordy-Collins, 2001a; Reinhard, 1999; Ühle, 1903; Verano, 1998; Verano \& Cordy-Collins, 1986; e.o). En otros casos, parece haber motivo de debate, sea por lo que concierne la interpretación del sentido a darle al sacrificio (Lyon, 1995: 383-386 acerca de los restos humanos excavados en la plataforma Las Avispas en Chan Chan por Pozorski, 1980), sea sobre la misma existencia del sacrificio (Sutter, 2001: 30 para los sacrificios de niños en la Huaca de la Luna en Bourget, 2001b). Sin embargo, no siendo la norma la muerte por sacrificio y siendo los sacrificados objeto de un tratamiento diferente del reservado a los individuos fallecidos de muerte natural, la mayoría de los autores parecen estar de acuerdo acerca de dos indicadores arqueológicos diagnósticos: el contexto y la posición del cuerpo (o de las partes de cuerpo). Cuando estos dos elementos se ubican fuera de las normas habituales, la hipótesis del sacrificio debe ser considerada. Existe una gran variedad

(13) Operación ritual compleja realizada con el concurso directo del Inca y que implicaba sacrificios humanos a través del conjunto del Imperio ( $c f$. Velasco de Tord, 1978).

(14) Taylor (1987: 277, nota 2) explica que "En la versión francesa de este texto, asimilamos pura al nombre de un mes determinado (Avila 1980[1608?]: 235). Sin embargo, la regularidad de los ritos descritos en otras fuentes nos hace pensar que se trata de ceremonias realizadas cada mes". En la mencionada versión, se usa del término "en el mes de Pura". Según Fernández (1571 in Bauer \& Dearborn, 1995: tabla 2), "Pura Opiaiquiz" corresponde al primer mes del año en el calendario inca, es decir, el mes comenzando el 23 de diciembre, el día siguiente al solsticio de invierno (o de verano en el hemisferio sur) según el calendario gregoriano. Él es el único cronista a usar este término. González Holguín (1989[1608]) traduce pura por "entre uno y el otro". Lo ilustra mediante varias expresiones todas asociadas con las fases de la luna y donde el término pura parece corresponder a la media luna. 
de formas de sacrificios en el registro arqueológico andino ( $c f$. Benson \& Cook, 2001; Verano, 1995). Para la zona y el periodo que nos interesan aquí, aislé de manera sistemática los hallazgos de restos humanos que presentan los indicadores mencionados arriba. Se clasificaron en dos categorías: niños y adultos (15). Los sacrificios de bebés y niños son los más frecuentes: 10 contextos se contabilizaron en el área de estudio (Cuadro 4).

Los sacrificios $n^{\circ} 1 \mathrm{y} \mathrm{n}^{\circ} 2$, encontrados en el Recinto Sagrado cerca a los templos, podrían corresponder a los niños sacrificados en honor a Pachacamac mencionados en las crónicas, aunque es difícil decir en qué medida esta interpretación puede ser aplicada al pasado lejano, además de que los criterios de Franco (1993b) para establecer que se tratan de sacrificios no son detallados. El sacrificio $n^{\circ} 9$ es semejante al $n^{\circ} 1$, pero no tenemos ningún dato del contexto que permita ir más allá en la interpretación.

Desde el punto de vista cronológico, la capa superficial donde se encontraron los sacrificios $\mathrm{N}^{\circ} 2$ sugiere que estos son tardíos. Franco no señala desmembramiento para estos fardos, podemos pues postular que dicha práctica, atestiguada en el Horizonte Medio por los sacrificios $\mathrm{n}^{\circ} 1 \mathrm{y} \mathrm{n}^{\circ} 9$, no se perpetuó en los periodos siguientes. En efecto, los cuerpos de los sacrificados $n^{\circ} 3$ a n ${ }^{\circ} 8$ - posteriores- están todos en posición anatómica.

\section{Cuadro 4 - Sacrificios de niños en contextos arqueológicos en Pachacamac y su} comarca.

\begin{tabular}{|c|c|c|c|c|c|c|}
\hline \multicolumn{2}{|c|}{ Sitio } & Localización & Descripción & Contexto & Periodo & Fuente \\
\hline 1 & Pachacamac & Cementerio I & $\begin{array}{l}\text { Fardo de bebé } \\
\text { decapitado y } \\
\text { desmembrado }\end{array}$ & Cementerio & $\begin{array}{l}\text { Horizonte } \\
\text { Medio }\end{array}$ & $\begin{array}{l}\text { Fleming, 1983: } \\
\text { 65; 1986: fig. 4; } \\
\text { Fleming et al., } \\
\text { 1983: 154-155 }\end{array}$ \\
\hline 2 & Pachacamac & Cementerio I & $\begin{array}{l}\text { Fardos de bebés } \\
\text { sacrificados }\end{array}$ & $\begin{array}{l}\text { Frente N del } \\
\text { Templo Viejo }\end{array}$ & No precisado & $\begin{array}{l}\text { Franco, 1993b: } \\
46-47\end{array}$ \\
\hline 3 & Pachacamac & Pirámide 3 & $\begin{array}{l}\text { Ent.2: fardo de } \\
\text { bebé echado } \\
\text { de espalda }\end{array}$ & $\begin{array}{l}\text { Abajo de } \\
\text { la base } \\
\text { de un muro }\end{array}$ & $\begin{array}{l}\text { Intermedio } \\
\text { Tardío }\end{array}$ & $\begin{array}{l}\text { Eeckhout, } \\
\text { 1995: 93-94 }\end{array}$ \\
\hline 4 & Pachacamac & Pirámide 3 & $\begin{array}{l}\text { Ent.14: niño } \\
\text { echado de } \\
\text { costado }\end{array}$ & $\begin{array}{l}\text { Relleno de } \\
\text { fundación }\end{array}$ & $\begin{array}{l}\text { Intermedio } \\
\text { Tardío }\end{array}$ & $\begin{array}{l}\text { Eeckhout, } \\
\text { \& Farfán, } 2001\end{array}$ \\
\hline 5 & Pachacamac & Pirámide 3 & $\begin{array}{l}\text { Ent.1: fardo de } \\
\text { bebé echado } \\
\text { de espalda }\end{array}$ & $\begin{array}{l}\text { Capa de } \\
\text { relleno }\end{array}$ & $\begin{array}{l}\text { Intermedio } \\
\text { Tardío }\end{array}$ & $\begin{array}{l}\text { Eeckhout, } \\
\text { 1999a: } 350\end{array}$ \\
\hline
\end{tabular}

(15) Por supuesto sólo se consideraron aquí los contextos intactos; los restos humanos procedentes de contextos saqueados son mucho más numerosos, pero su interpretación debe ponerse en tela de juicio. 


\begin{tabular}{|c|c|c|c|c|c|c|}
\hline 6 & Pachacamac & Pirámide 3 & $\begin{array}{l}\text { Ent.1: fardo de } \\
\text { bebé echado } \\
\text { de espalda }\end{array}$ & $\begin{array}{l}\text { Cámara } \\
\text { funeraria }\end{array}$ & $\begin{array}{l}\text { Intermedio } \\
\text { Tardío }\end{array}$ & $\begin{array}{l}\text { Eeckhout, } \\
\text { 1999c: } 189, \\
\text { fig. } 17\end{array}$ \\
\hline 7 & Pachacamac & Pirámide 3 & $\begin{array}{l}\text { Ent.3: fardo } \\
\text { de bebé }\end{array}$ & $\begin{array}{l}\text { Cámara } \\
\text { funeraria }\end{array}$ & $\begin{array}{l}\text { Horizonte } \\
\text { Tardío }\end{array}$ & $\begin{array}{l}\text { Eeckhout, } \\
\text { 1995: } 91\end{array}$ \\
\hline 8 & $\begin{array}{l}\text { Pampa de } \\
\text { las Flores }\end{array}$ & Pirámide 3 & $\begin{array}{l}3 \text { fardos de } \\
\text { bebés echados } \\
\text { de espalda }\end{array}$ & $\begin{array}{l}\text { Entierro } \\
\text { colectivo }\end{array}$ & Transición & Eeckhout., 1999b \\
\hline 9 & Lima & No precisado & $\begin{array}{l}\text { Fardo de bebé } \\
\text { decapitado y } \\
\text { desmembrado }\end{array}$ & No precisado & $\begin{array}{l}\text { Horizonte } \\
\text { Medio }\end{array}$ & $\begin{array}{l}\text { Fleming, 1983: } 75 \\
\text { Fleming et al., } \\
\text { 1983: 155-156 }\end{array}$ \\
\hline 10 & Avillay & Sector IIa & Cráneo de bebé & $\begin{array}{l}\text { Relleno de } \\
\text { fundación }\end{array}$ & $\begin{array}{l}\text { ¿Horizonte } \\
\text { Tardío? }\end{array}$ & $\begin{array}{l}\text { Feltham, } \\
\text { 1983: 760-824 }\end{array}$ \\
\hline
\end{tabular}

Además, comparten una particularidad cuya recurrencia sistemática podría revelarse un rasgo específico de los bebés sacrificados: están dispuestos horizontalmente, echados en la espalda o de costado, al contrario de los bebés enterrados en los cementerios, los cuales se colocan verticalmente y en posición fetal. Es muy interesante notar que la mayoría de los adultos sacrificados también se colocaron horizontalmente, echados de espalda (ver más abajo). Sin embargo, más que todo, es el contexto el que sugiere que estos niños han sido sacrificados: para $\operatorname{los} n^{\circ} 3 \mathrm{y} \mathrm{n}^{\circ} 4$, corresponden a capas de fundación que precedieron directamente a la construcción de edificios monumentales (Fig. 2). Quizás se enterraron vivos, tal como se relata en las fuentes

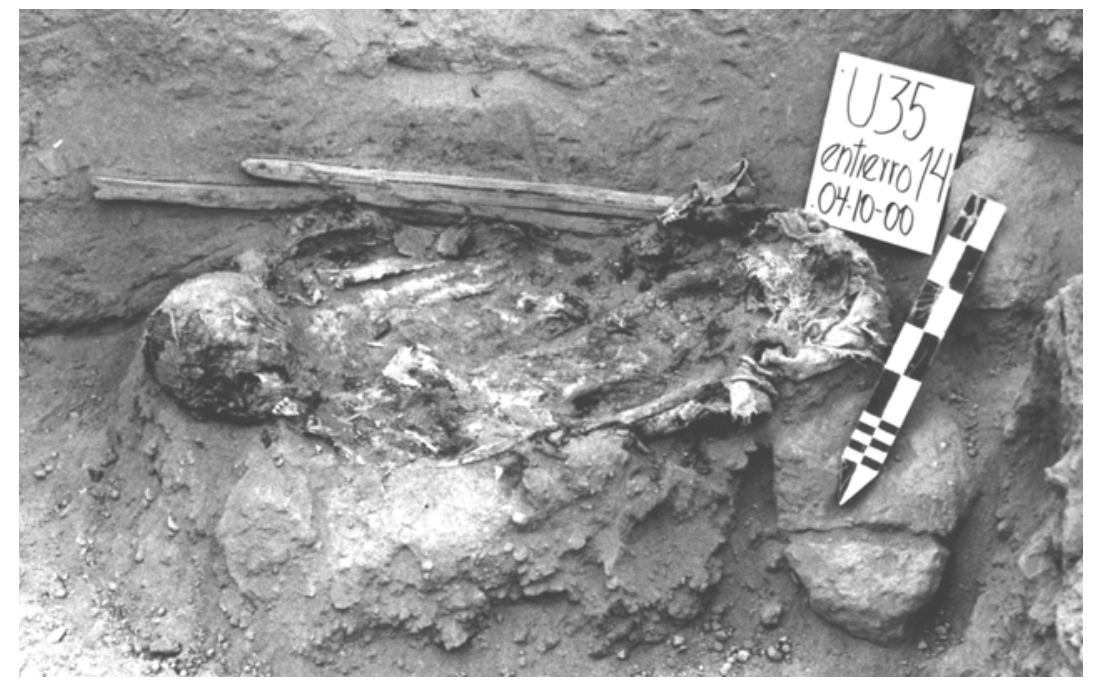

Fig. 2 - Sacrificio de niño encontrado en las fundaciones de la primera plataforma del Templo del Mono en Pachacamac (temporada 2000). 
ethnohistóricas. En cuanto a los sacrificados $n^{\circ} 5$ a $n^{\circ} 8$, se trata de acompañantes de adultos fallecidos de muerte natural $\left(n^{\circ} 5, n^{\circ} 6 \mathrm{y} \mathrm{n}^{\circ} 7\right)$ o probablemente sacrificados $\left(n^{\circ} 8\right)$. No tenemos ningún dato antropofísico que permita precisar la manera cómo se dio muerte a estos niños. Feltham interpretó la presencia de un cráneo de bebé $\left(\mathrm{n}^{\circ} 10\right)$ en la capa de relleno constructivo en Avillay como un sacrificio de fundación.

Los sacrificios de adultos conocidos en el registro arqueológico regional son más escasos (Cuadro 5), si uno exceptua el famoso cementerio de mujeres sacrificadas excavado por Ühle en 1896. Ühle (1903: 85) y Fleming (1983) explican detalladamente cómo se les dio muerte. La presión fuerte de la soga de estrangulación sobre la garganta de las mujeres sacrificadas ha producido una dislocación de la mandíbula y la piel se secó fuertemente sobre ésta, así la abertura maxilar no puede reducirse. Los cabellos todavía están presentes y se observan vagas huellas de pintura bermellón en algunas caras. En el cementerio del Templo del Sol existe una gran uniformidad entre los cráneos de la zona de las mujeres sacrificadas, algo que sugiere que se trata de gentes procedentes de la sierra, pues son dolicocéfalos (Ühle, 1903: 87). Este autor piensa que dichas mujeres son vírgenes del acllahuasi establecido por los incas en Pachacamac (Ühle, 1903: 87).

No hay ninguna ilustración o análisis en cuanto al fardo mencionado por Franco (1993b: 46) quien relaciona este hallazgo y la ceremonia Inca de la capac hucha (ver arriba) cuando los checas serranos venían anualmente a sacrificar un hombre y una mujer en Pachacamac.

En Pampa de las Flores, la posición del cuerpo de la sepultura E17 (echada de espalda, con las manos cruzadas a la altura del corazón), el contexto del hallazgo (capa de relleno asociada al abandono voluntario de una pirámide con rampa), los elementos asociados (otros entierros, incluidos bebés probablemente sacrificados) y el análisis antropofísico sugieren que se trata de una aclla de menos de 40 años, sacrificada por estrangulación o ahogamiento (Eeckhout, 1999a; 1999b).

\section{Cuadro 5 - Sacrificios de adultos en contextos arqueológicos en Pachacamac y su comarca.}

\begin{tabular}{|c|c|c|c|c|c|c|}
\hline & Sitio & Localización & Descripción & Contexto & Periodo & Fuente \\
\hline 1 & Pachacamac & $\begin{array}{l}\text { Templo } \\
\text { del Sol }\end{array}$ & $\begin{array}{l}\text { Mujeres ahogadas, } \\
\text { posición del cuerpo } \\
\text { no precisada }\end{array}$ & $\begin{array}{l}\text { Terraza } \\
\text { funeraria }\end{array}$ & $\begin{array}{l}\text { Horizonte } \\
\text { Tardío }\end{array}$ & $\begin{array}{l}\text { Ühle, 1903: } \\
\text { 84-88. }\end{array}$ \\
\hline 2 & Pachacamac & Cementerio I & $\begin{array}{l}\text { Fardo de mujer } \\
\text { desarticulada }\end{array}$ & $\begin{array}{l}\text { Frente N. del } \\
\text { TemploViejo } \\
\text { y decapitada }\end{array}$ & $\begin{array}{l}\text { N.P. } \\
\text { (Tardío) }\end{array}$ & $\begin{array}{l}\text { Franco, } \\
\text { 1993b: } 46\end{array}$ \\
\hline 3 & $\begin{array}{l}\text { Pampa } \\
\text { de las Flores }\end{array}$ & Pirámide 3 & $\begin{array}{l}\text { Una mujer ahogada } \\
\text { echada de espalda, } \\
\text { otras } 2 \text { N.D. }\end{array}$ & $\begin{array}{l}\text { Entierro } \\
\text { colectivo }\end{array}$ & Transición & $\begin{array}{l}\text { Eeckhout, } \\
\text { 1999b }\end{array}$ \\
\hline
\end{tabular}


La base de datos se revela entonces bastante reducida. Sin embargo, sobresalen dos constantes: el sexo (siempre femenino) y el periodo (Tardío). Preliminarmente se puede deducir que los sacrificos humanos de adulto se practicaron siguiendo la influencia Inca, por ejemplo en el marco de la ceremonia de la capac hucha, como lo propone Franco. Sin embargo, en el caso de la sacrificada de Pampa de las Flores, el contexto es diferente, sugiriendo un papel de acompañante de un difunto importante, un curaca cuya pirámide fue la residencia (ver Eeckhout, 1999b). Las fuentes etnohistóricas documentan ampliamente dicha práctica, como se ha visto. Asimismo, en la costa existe una larga tradición de sacrificios de acompañantes donde las mujeres están muy bien representadas, como lo atestiguan las excavaciones de Sipán (Alva Alva, 1999; Alva Alva \& Donnan, 1993) o de Chan Chan (Pozorski, 1980). Tenemos aquí una coincidencia bastante estrecha entre fuentes arqueológicas y etnohistóricas: por un lado, sacrificados dedicados a una divinidad o marcando algún evento específico, y por otro lado sacrificados acompañando a un difunto de estatus especial.

\section{1. 2. Sacrificios de camélidos}

Polia (1999: 114) explica que el sacrifico de camélidos, especialmente de llamas (Lama glama) se practicaba bastante y pertenecía a la categoría de los sacrificios mayores (ver también Rowe, 1946: 308-309). Valera (1968[1585-1589]: 168) diferencia los sacrificios sangrientos (harpay) de los sacrificios sin derramamiento de sangre (haspay). Duviols (1986: 5, 8, 9, 17 \& ss.) mencionó un sinnúmero de casos de sacrificios de llamas con modalidades diversas. Se debe sin embargo precisar que muchos casos descritos en Duviols se relacionan con los rituales realizados durante los entierros secundarios de difuntos sacados de sus cementerios cristianos de origen. Otros sirven de ofrendas para los ancestros regularmente extraídos de sus sepulcros para ser honrados (Duviols, 1986: 26). En este caso, se rociaban con la sangre de los animales las momias, así como los lugares por donde pasaban en ceremonia. La carne la consumían los invitados (Duviols, 1986:13, 15 \& ss.). Un testimonio de extirpación de idolatría menciona la presencia en una cámara funeraria múltiple de pedazos de carne y del cadáver de una llama joven cerca a los fardos de ancestros (Duviols, 1986: 17). A las huacas generalmente se les ofrece la sangre y el sebo del animal sacrificado (Arriaga, 1999[1621]: 52; Duviols, 1986: 7, 10, 20 \& ss.; Hernández Príncipe, 1919[1622]: 186187; Polia, 1999: 115). Arriaga (1999[1621]: 51) describe las ceremonias de la siguiente manera:

“También ofrecen llamas (...) y esto suele ser siempre en las fiestas mas solemnes de las huacas, y las sacan enramadas de flores. Atan la llama de una piedra grande, hacénla de cinco o seis vueltas a la redonda y luego la abren por el lado del corazón y se le sacan, y le suelen comer crudo a bocados, y con la sangre asperjan la huaca, y la carne se reparte entre los ministros del sacrificio, y también suelen dar de ella a los demás indios (...) Otras veces los mismos indios que tienen ganado dan sus corderos y llamas para que los sacrifiquen para el aumento de su ganado".

El famoso extirpador explica haber descubierto numerosos huesos de llamas cerca de ciertas huacas de la sierra como Llaxavilca (Arriaga, 1999[1621]: 95), Libiac (Arriaga, 1999[1621]: 98), y otras (Arriaga, 1999[1621]: 100). Se sacrificaban también en el marco de la ceremonia realizada en la zona de Huarochirí 
en honor a Chaupiñamoc — hermana de Paricaca (Arriaga, 1999[1621]: 147) — y de Chuquisuso, diosa ancestral de los Chahuincho, un ayllu yauyo (Avila, 1980[1608?]: 65).

Desde el punto de vista arqueológico, los sacrificios de camélidos se atestiguan por los hallazgos en el Templo Viejo (Paredes \& Franco, 1989b: 72-73), el Edificio Pintado (Franco, 1993a: 66; Franco \& Paredes, 2000: 616-617), la pirámide con rampa III (Eeckhout, 1999a: 330 \& ss.; Eeckhout \& Farfán, 2001), así como en diferentes sitios del valle de Lurín tales como Pampa de las Flores y Chontay (Eeckhout, 1999a: 331, 340) (Fig. 3). Escasamente se encontraron los animales enteros; generalmente han sido desmembrados y/o quemados. Los contextos indican que se trata mayormente de ofrendas ligadas a los ritos funerarios. La práctica de sacrificios de camélidos a gran escala (varias docenas, tal vez varios centenares de individuos de todas edades y ambos sexos) parece asociada a ciertos rituales de fundación, tal como lo atestiguan los hallazgos encontrados durante la última temporada de excavaciones llevada a cabo en la pirámide III (Eeckhout \& Farfán, 2001: 17-33).

\section{1. 3. Sacrificios de cuyes}

Tradicionalmente considerado como una de las comidas preferidas de los dioses, el cuy (Cavia porcellus) se sacrificaba en innumerables ocasiones y de diferentes maneras (Rowe, 1946: 219, 306, 309-310; Sandweiss \& Wing, 1997: 50-51). En la

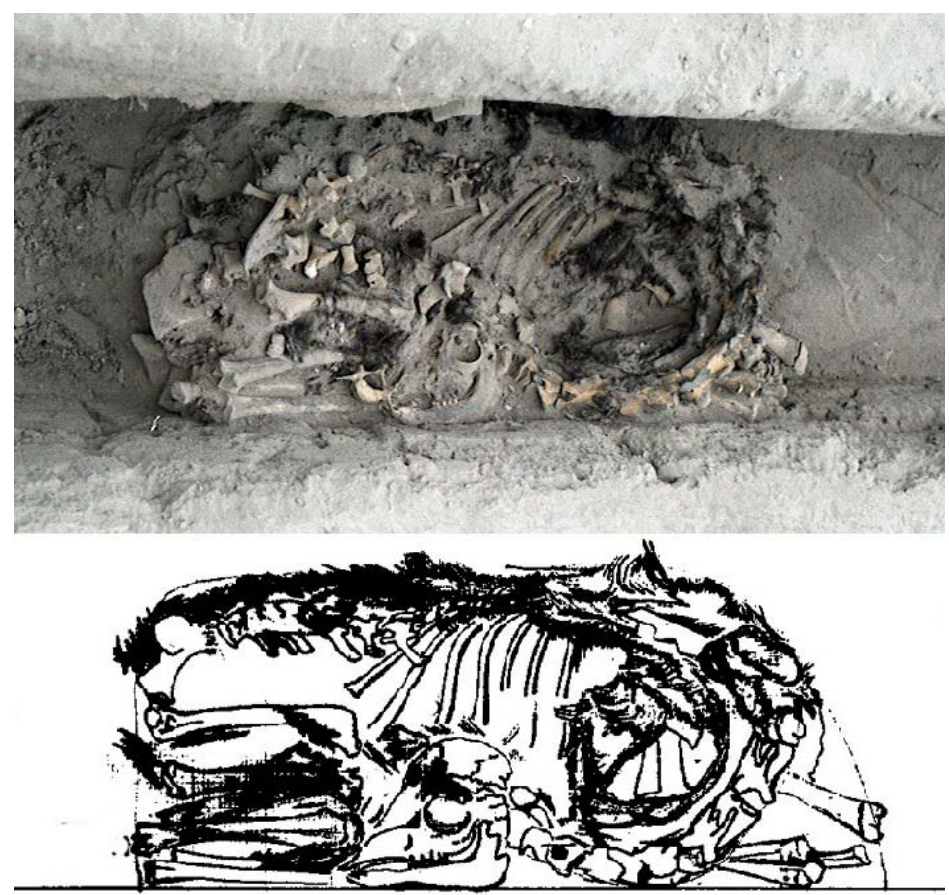

Fig. 3 - Entierro de camélido adulto. Pachacamac, Pirámide III (temporada 2000). 
región que nos interesa, sacrificaban cuyes en la ceremonia del primer corte de cabellos de los niños (Avila, 1980[1608?]: 229), también en los rituales relacionados con la limpieza de acequias (Avila, 1980[1608?]: 211), los ritos terapéuticos y los de adivinación (Polia, 1999: 112; Duviols, 1986: 8). Los muros de casas recién construidas se rociaban con sangre de cuyes antes de poner el techo, con el fin de garantizar su solidez (Duviols, 1986: 15 \& ss.). Ofrendas de cuyes a Pachacamac se relatan en Avila (1980[1608?]: 135), cuando un grupo yauyos viene a implorar a la divinidad que le devuelva a su hijo Locllahuancupa, quitado como castigo por haber descuidado a su huaca. También se mencionan los cuyes en el marco del culto a la diosa Mama (o Chaupiñamca), esposa de Pachacamac (Avila, 1980[1608?]: 65, 103; Hernández Príncipe, 1919: 181), y a otras huacas (Duviols, 1986: 10 \& ss.; Hernández Príncipe, 1919[1622]: 186-187) como Chuquisuso o Macahuisa entre los yauyos (Avila, 1980[1608?]: 65, 131). Se les sacrificaba abriéndolos con la uña del pulgar, ahogándolos en un mate de agua mientras se dirigían a la huaca, luego se les destripaba desde arriba hasta abajo (Arriaga, 1999[1621]: 51; Duviols, 1986: 6). Se rociaban los ídolos con su sangre (Hernández Príncipe, 1919[1622]: 186), así como los campos en época de siembra (Duviols, 1986: 44 \& ss.); parece que parte de los cuerpos luego se enterraban cerca (Duviols, 1986: 21).

Los sacrificios de cuyes son frecuentes, tal como lo atestiguan las fuentes arqueológicas (Sandweiss \& Wing, 1997) y etnográficas (Morales, 1995: 99-132). En nuestro registro, los contextos donde aparecen son sumamente diversos, así como las interpretaciones que sugieren (Cuadro 6).

Cuadro 6 - Sacrificio de cuyes.

\begin{tabular}{|c|c|c|c|c|c|c|}
\hline & Sitio & Localización & Descripción & Contexto & Período & Fuente \\
\hline 1 & Pachacamac & Templo Viejo & $\begin{array}{l}\text { Cuyes } \\
\text { sacrificados }\end{array}$ & Recinto superior & H. Tardío & $\begin{array}{l}\text { Franco, } \\
\text { 1993b: } 61\end{array}$ \\
\hline 2 & Pachacamac & Templo Viejo & $\begin{array}{l}\text { Cuyes } \\
\text { sacrificados }\end{array}$ & Recinto principal & $\begin{array}{l}\text { Int. } \\
\text { Temprano }\end{array}$ & $\begin{array}{l}\text { Franco, } \\
\text { 1993b: } 54\end{array}$ \\
\hline 3 & Pachacamac & Templo Viejo & $\begin{array}{l}\text { Cuyes } \\
\text { sacrificados }\end{array}$ & $\begin{array}{l}\text { Relleno de } \\
\text { abandono }\end{array}$ & H.m. 3-4 & $\begin{array}{l}\text { Franco, } \\
\text { 1993b: } 60\end{array}$ \\
\hline 4 & Pachacamac & $\begin{array}{l}\text { Templo } \\
\text { Pintado }\end{array}$ & Cuyes envueltos & Sobre las gradas & H. Tardío & $\begin{array}{l}\text { Paredes, } \\
\text { 1985: } 74\end{array}$ \\
\hline 5 & Pachacamac & Pirámides & Cuyes envueltos & Patios posteriores & Tardío & $\begin{array}{l}\text { Paredes, } \\
\text { 1985: } 74\end{array}$ \\
\hline 6 & Pachacamac & Pirámide 3 & $\begin{array}{l}\text { Ych-00-H47 } \\
\text { huesos de cuy }\end{array}$ & U36 ofrenda & Tardío & $\begin{array}{l}\text { Eeckhout \& } \\
\text { Farfán, 2001: } 26\end{array}$ \\
\hline 7 & Pachacamac & Pirámide 3 & $\begin{array}{l}\text { Ych-00-H1 } \\
\text { cuy }\end{array}$ & U35 ofrenda & Tardío & $\begin{array}{l}\text { Eeckhout \& } \\
\text { Farfán, 2001: } 94\end{array}$ \\
\hline
\end{tabular}




\begin{tabular}{|c|c|c|c|c|c|}
\hline Sitio & Localización & Descripción & Contexto & Período & Fuente \\
\hline 8 Pachacamac & Pirámide 3 & $\begin{array}{l}\text { Ych-00-H2 } \\
\text { cuyes }\end{array}$ & U35 ofrenda & Tardío & $\begin{array}{l}\text { Eeckhout \& } \\
\text { Farfán, 2001: } 94\end{array}$ \\
\hline 9 Pachacamac & Pirámide 3 & $\begin{array}{l}\text { Ych-00-H3 } \\
\text { huesos de cuy }\end{array}$ & U35 ofrenda & Tardío & $\begin{array}{l}\text { Eeckhout \& } \\
\text { Farfán, 2001: } 94\end{array}$ \\
\hline 10 Pachacamac & Pirámide 3 & $\begin{array}{l}\text { Ych-00-H4 } \\
\text { cuy }\end{array}$ & U35 ofrenda & Tardío & $\begin{array}{l}\text { Eeckhout \& } \\
\text { Farfán, 2001: } 92\end{array}$ \\
\hline 11 Pachacamac & Pirámide 3 & $\begin{array}{l}\text { Ych-00-H5 } \\
\text { restos de cuy }\end{array}$ & U35 ofrenda & Tardío & $\begin{array}{l}\text { Eeckhout \& } \\
\text { Farfán, 2001: } 92\end{array}$ \\
\hline 12 Pachacamac & Pirámide 3 & $\begin{array}{l}\text { Ych-00-H6 } \\
\text { cuy }\end{array}$ & U35 ofrenda & Tardío & $\begin{array}{l}\text { Eeckhout \& } \\
\text { Farfán, 2001: } 92\end{array}$ \\
\hline 13 Pachacamac & Pirámide 3 & $\begin{array}{l}\text { Ych-00-H7 } \\
\text { restos de cuy }\end{array}$ & U35 ofrenda & Tardío & $\begin{array}{l}\text { Eeckhout \& } \\
\text { Farfán, 2001: } 92\end{array}$ \\
\hline Sitio & Localización & Descripción & Contexto & Periodo & Fuente \\
\hline 14 Pachacamac & Pirámide 3 & $\begin{array}{l}\text { Ych-00-H8 } \\
\text { restos de cuy }\end{array}$ & U35 ofrenda & Tardío & $\begin{array}{l}\text { Eeckhout \& } \\
\text { Farfán, 2001: } 92\end{array}$ \\
\hline 15 Pachacamac & Pirámide 3 & $\begin{array}{l}\text { Ych-00-H9 } \\
5 \text { cuyes }\end{array}$ & U35 ofrendas & Tardío & $\begin{array}{l}\text { Eeckhout \& } \\
\text { Farfán, 2001: } 92\end{array}$ \\
\hline 16 Pachacamac & Pirámide 3 & $\begin{array}{l}\text { Ych-00-H10 } \\
\text { restos de cuy }\end{array}$ & U35 ofrenda & Tardío & $\begin{array}{l}\text { Eeckhout \& } \\
\text { Farfán, 2001: } 92\end{array}$ \\
\hline 17 Pachacamac & Pirámide 3 & $\begin{array}{l}\text { Ych-00-H11 } \\
6 \text { cuyes }\end{array}$ & U35 ofrendas & Tardío & $\begin{array}{l}\text { Eeckhout \& } \\
\text { Farfán, 2001: } 92\end{array}$ \\
\hline 18 Pachacamac & Pirámide 3 & $\begin{array}{l}\text { Ych-00-H13 } \\
1 \text { cuy }\end{array}$ & U35 ofrenda & Tardío & $\begin{array}{l}\text { Eeckhout \& } \\
\text { Farfán, 2001: } 92\end{array}$ \\
\hline 19 Pachacamac & Pirámide 3 & $\begin{array}{l}\text { Ych-00-H15 } \\
2 \text { cuyes }\end{array}$ & U35 ofrendas & Tardío & $\begin{array}{l}\text { Eeckhout \& } \\
\text { Farfán, 2001: } 95\end{array}$ \\
\hline 20 Pachacamac & Pirámide 3 & $\begin{array}{l}\text { Ych-00-H35 } \\
1 \text { cuy }\end{array}$ & $\begin{array}{l}\text { U35 ofrenda/ } \\
\text { tumba }\end{array}$ & Tardío & $\begin{array}{l}\text { Eeckhout \& } \\
\text { Farfán, 2001: } 95\end{array}$ \\
\hline 21 Pachacamac & Pirámide 3 & $\begin{array}{l}\text { Ych-00-H26 } \\
1 \text { cuy }\end{array}$ & U41 ofrenda & Tardío & $\begin{array}{l}\text { Eeckhout \& } \\
\text { Farfán, 2001: } 113\end{array}$ \\
\hline 22 Pachacamac & Pirámide 3 & $\begin{array}{l}\text { Ych-00-H46 } \\
3 \text { cuyes }\end{array}$ & U42 ofrendas & Tardío & $\begin{array}{l}\text { Eeckhout \& } \\
\text { Farfán, 2001: } 120\end{array}$ \\
\hline
\end{tabular}




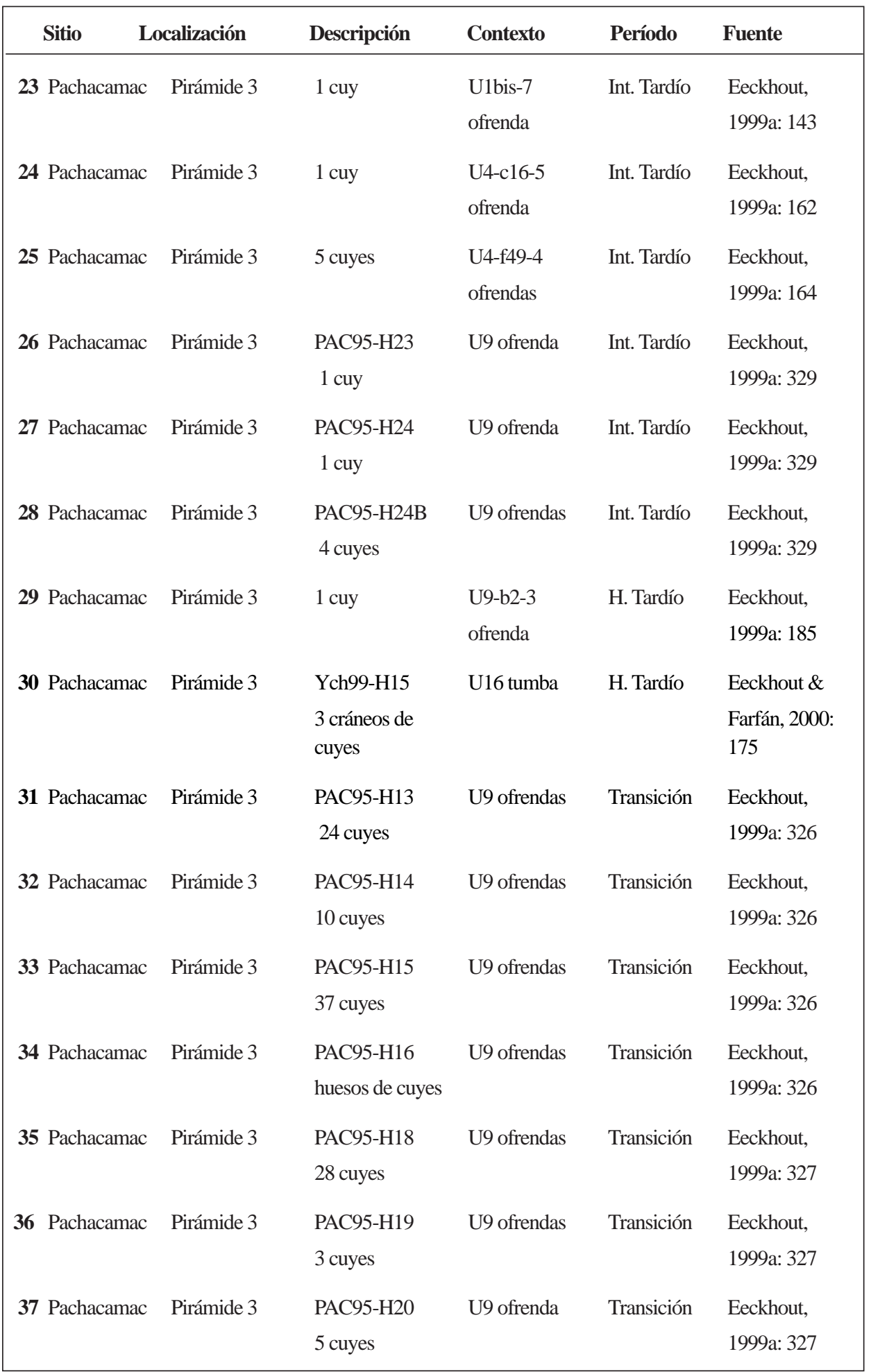




\begin{tabular}{|c|c|c|c|c|c|}
\hline Sitio & Localización & Descripción & Contexto & Período & Fuente \\
\hline $\begin{array}{l}38 \text { Pampa } \\
\text { de Flores }\end{array}$ & Cementerio & P1-3: 1 cuy & Ofrenda & Tardío & $\begin{array}{l}\text { Eeckhout, } \\
\text { 1999a: } 267\end{array}$ \\
\hline $\begin{array}{l}39 \text { Pampa } \\
\text { de Flores }\end{array}$ & Cementerio & E4: 1 cuy & $\begin{array}{l}\text { Ofrenda } \\
\text { funeraria }\end{array}$ & Tardío & $\begin{array}{l}\text { Eeckhout, } \\
\text { 1999a: } 356\end{array}$ \\
\hline $\begin{array}{l}40 \text { Pampa } \\
\text { de Flores }\end{array}$ & Cementerio & E6: 2 cuyes & $\begin{array}{l}\text { Ofrendas } \\
\text { funerarias }\end{array}$ & Tardío & $\begin{array}{l}\text { Eeckhout, } \\
\text { 1999a: } 358\end{array}$ \\
\hline $\begin{array}{l}41 \text { Pampa } \\
\text { de Flores }\end{array}$ & Pirámide 3 & $\begin{array}{l}\text { P17-18 } \\
\text { cabeza de cuy }\end{array}$ & $\begin{array}{l}\text { Capa de } \\
\text { fundación }\end{array}$ & Tardío & $\begin{array}{l}\text { Eeckhout, } \\
\text { 1999a: } 288\end{array}$ \\
\hline
\end{tabular}

Para los ítems 1 a 5, se trata, según los autores, de ofrendas de peregrinos. Los ítems 6 y 31 hasta 37 son muy tardíos, probablemente siguen a la conquista española. En efecto, desde el punto de vista estratigráfico, dichas ofrendas son posteriores a la primera fase de saqueo, o sea, el periodo de Transición. Quizás corresponden a rituales para los ancestros enterrados en la pirámide III, cuyas tumbas habían sido saqueadas (16). Los ítems 7 hasta 20 proceden del mismo contexto: la primera plataforma de la pirámide III-C. Esta pirámide es muy especial: tiene rampa lateral, no presenta huellas de ocupación doméstica, y la disposición de los recintos sugiere más una función ritual que residencial (Eeckhout, 2002a; Eeckhout \& Farfán, 2001). Además, las ofrendas en ese lugar son muy numerosas, las mencionadas aquí sólo constituyen una parte. En la primera plataforma, las ofrendas de cuyes están asociadas a postes de madera dispuestos en forma de triángulo frente al acceso a la plataforma superior (Fig. 4). En esta última se hallaron los ítems 21 y 22 , cuyos contextos son similares a los descritos justo antes. Es probable que estas ofrendas correspondan por una parte a los rituales de fundación de este templo y por otra parte a las ceremonias que luego se llevaron a cabo en el sitio.

Todavía no tenemos fechados para este conjunto, pues el material está en proceso de estudio, pero los datos de campo sugieren que se trata de un edificio más antiguo que el resto del complejo piramidal III (fechado de 1400 a 1470 d.n.e., cf. Michzincky et al., 2003). Los ítems 23 a 25 y 41 proceden de capas de fundación de las pirámides con rampa central y por lo tanto reflejan probablemente los rituales relacionados con el inicio de la construcción de estos palacios de señores locales. De la misma manera, los ítems 26 a 29, en cada caso, están asociados con fases de remodelación arquitectónica de la entrada principal a la pirámide III-A, incluso cuando el lugar ya no estaba habitado,es decir, cuando la pirámide se usó como cementerio. Los ítems 30, 39 y 40 eran parte del ajuar funerario de individuos enterrados bien en la piramide III-A (entierro intrusivo Horizonte Tardío), o bien en el cementerio de Pampa de las Flores (Intermedio Tardío y HorizonteTardío). El ítem 38 también procede de este cementerio pero no estuvo asociado con una tumba: se encontró en una capa superior, donde se registró la presencia de restos de comida y fosas pequeñas para ofrendas: quizás son indicios

(16) Para una descripción completa de los contextos y argumentos en favor de esta interpretación, ver Eeckhout, 1999a: 183-190. 


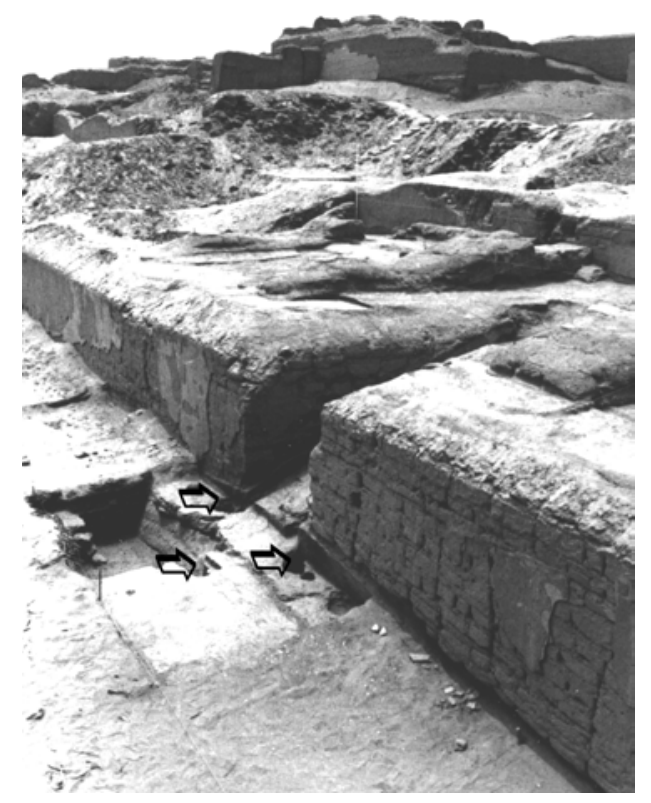

Fig. 4 - Plataformas superiores del Templo del Mono en Pachacamac. Por cada lado del acceso se puede apreciar un hueco de poste; un tercer hueco se encuentra frente a la entrada.

relacionados con el culto a los muertos, regularmente visitados por sus familiares, quienes les hacían ofrendas (17).

Se nota, pues, una cierta coincidencia entre datos etnohistóricos y arqueológicos. Los cuyes son ofrendas para los ancestros, los dioses, o para marcar eventos específicos como la fundación de edificios importantes.

\section{1. 4. Otros sacrificios}

Rowe (1946: 306) explica que entre los incas generalmente no se sacrificaban animales no domesticados, excepto ciertas aves en los ritos propiciatorios relacionados con las batallas. En nuestra área de estudio, Hernández Príncipe (1919[1622]: 188) menciona que el demonio se apareció varias veces a los aborígenes durante las campañas de extirpación de idolatrías y les dejó como mandato "(...) que no maten las arañas, ni zapos, ni culebras, ni coman carneros blancos, sino que los guarden para el sacrificio". No se proporciona ningún detalle respecto a la índole ni tampoco a las circunstancias de dichos sacrificios. Según Polia (1999: 185):

"La rana y el sapo en el mundo andino en general son animales relacionados con el agua y la tierra y, por lo tanto, cargados de valores simbólicos concernientes la esfera de la humedad, de la fertilidad, fecundidad, reproducción, etc. (...) Con la llegada de los españoles el simbolismo del sapo, como el de la serpiente, se carga de los valores negativos

(17) Para una descripción completa de los contextos y argumentos en favor de esta interpretación, ver Eeckhout, 1999a: 280. 
atribuidos a este animal en el folklore mágico y en el simbolismo de la demonología europea medieval y renacentista que relaciona este batracio con el diablo".

En un testimonio de extirpación de idolatría en el valle de Pisco, fechado en el año 1620, cangrejos, ranas y serpientes son designados como responsables de los eclipses de luna (Rostworowski, 1989, App.VIII: 292).

Una serie de animales probablemente sacrificados se hallaron en varios contextos arqueológicos en Pachacamac y Lurín, especialmente ranas y perros. Por lo que concierne a las primeras (Batrachoprinus sp. y Bufo spinulosus limensis), se constata que frecuentemente están asociadas con cuyes en las ofrendas (Eeckhout, 1999a: 326-327). Por regla general, se encuentra un solo batracio desecado en la parte superior de la ofrenda, lo que sugiere que fue el último sacrificado. Un ejemplo aislado, también voluntariamente desecado, se encontró cerca a una importante ofrenda funeraria del cementerio de Pampa de las Flores (Eeckhout, 1999a: 276). Paredes \& Franco (1989a: 11) relatan que en contextos asociados al estilo Horizonte Medio 3-4 del Templo Viejo de Pachacamac, “(...) es frecuente el hallazgo de batracios disecados, algunos de ellos eviscerados a través de un corte en el abdomen, producido al parecer por uña”. Según los autores,

“(...) la presencia física de estos animales en los entierros los relaciona estrechamente a los cultos de propiciación del agua y las lluvias, ya que un estilo cerámico denominado Ichimay Bicromo e Ichimay Negro usa profusamente pequeñas ollas con la aplicación en los bordes de sapos escultóricos" (Paredes \& Franco, 1989a:11).

Esta interpretación la desarrollará Franco (1998: 64) para explicar el gran número de cuencos carenados con pequeños sapos rotos ex-profeso encontrados en las excavaciones de la pirámide II, un edificio del periodo Ychsma (Fig. 5). El análisis de los mitos y ritos relacionados con el dios Ychsma-Pachacamac ha mostrado que la luna y el mar participan del "grupo estructural costeño". Estos datos inconexos le hacen plausible la hipótesis a Franco, más todavía si uno piensa en la relación entre las ranas y la luna ( $c f$. supra Rostworowski, 1989, App.VIII: 292), un astro estrechamente ligado al culto de Pachacamac. En suma, es posible que las ofrendas de batracios y la destrucción voluntaria de vasijas decoradas con imágenes de estos mismos animales (un acto que aparece como una especie de metáfora del sacrificio) tengan una vinculación específica con el agua, un elemento sobre el cual Ychsma-Pachacamac, como dios lunar, tenía de alguna manera el control.

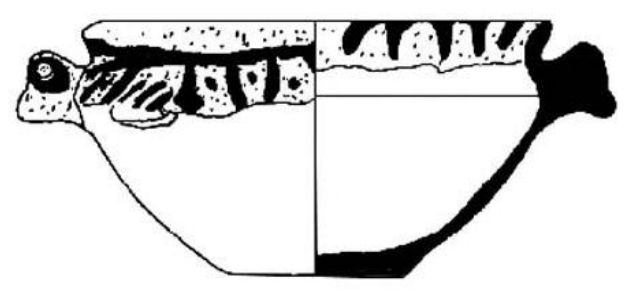

Fig. 5 - Cuenco carenado Negro-sobre-Blanco decorado con figurillas de sapos aplicados (Pachacamac, Pirámide III, Período Intermedio Tardío 7-8). 
Dos sepulturas de cánidos (Canis familiaris y Canis molosoides) se descubrieron durante las excavaciones llevadas a cabo en la pirámide III de Pachacamac (Eeckhout, 1995; 1999a: 370-371). Estaban asociadas con tumbas colectivas intrusivas fechadas en el Horizonte Tardío. Es interesante remarcar que los perros no se enterraron dentro de las estructuras funerarias de personas sino al lado, en la parte superior de la estratigrafía, algo que sugiere que se depositaron allá al final de los ritos de inhumación y que su sacrificio quizás se llevó a cabo en este momento. Paredes \& Franco (1989b: 53) encontraron el mismo tipo de patrón en las excavaciones de tumbas intrusivas saqueadas del Templo Viejo de Pachacamac. Sin duda se trata de contextos tardíos. En el Edificio Pintado, Paredes \& Franco (1989a: 74) informan de que "ofrendas y pagos procedentes de la llegada de los incas se hicieron con la colocación de paquetes con cuyes envueltos en pancas, entierros de perros (...)". Desafortunadamente, no proporcionan más precisiones sobre estos últimos. Considerando las recurrencias de asociaciones entre perros y sepulturas humanas, se puede postular que estos animales jugaban algún papel en los ritos de inhumación, y tal vez asumían una función psicopompa (18).

Finalmente, se debe evocar un rito relatado por Pedro Pizarro (1978[1571]: 246) en la época de la conquista, pero cuyo origen es sin duda pre-inca ( $c f$. Ravines 1990).

"En el ydolo de Pachacamac tenían por costumbre, cada día, de echar muchas cargas de sardinas, pequeñas como anchovetas frescas, en una plaça que estaua delante de la casa del ydolo. Echauan estas sardinas para que comiesen estas gallinazas y estos condóres, porque dezían se lo mandaua así su ydolo".

Según Rostworowski (1983: 44) se trata de un rito sustitutivo (los peces reemplazan el cuerpo desmembrado de la madre en el mito de Pachacamac y Vichama relatado por Calancha) ligado con creencias de fecundidad agrícola. Menzel (1977: 10) hace notar al respecto que las cabezas de anchovetas, así como el guano resultante de las deyecciones de aves marinas se usaron como abono en la costa:

"We can see, then, that the sea birds and anchovies had an important relationship to agricultural production (...)” (Menzel, 1977: 10) (19).

Esto permite establecer una relación directa entre varios atributos de la divinidad puestos en evidencia en el análisis de los mitos: el aspecto a la vez terrestre y marino, la asociación con los peces por un lado, con las plantas cultivadas por el otro, el papel de las aves marinas como agentes mediadores, la fertilidad y la fecundidad (20).

Aunque su clasificación en la categoría de los sacrificios animales pueda ser discutida, no puede pasar desapercibido el hallazgo de huesos de pescados, así como

(18) Entre los Moche del periodo Intermedio Temprano, el papel psicompopo de los perros domésticos está sugerido por la iconografía ( $c f$. Benson, 1991). Se les encuentra también en contextos funerarios acompañando a los difuntos humanos (p.e. Alva Alva \& Donnan, 1993: 160).

(19) Para la zona de Pachacamac, Cieza de León (1995[1551], I, cap 73: 216) menciona que cabezas de "sardinas" se enterraban con cada grano de maíz al momento de la siembra.

(20) Todos estos elementos están presentes en las pinturas de las gradas del Templo Pintado, lo que subraya la relación entre mitos y ritos y fortalece la interpretación aquí propuesta (para un examen detallado, ver Eeckhout 1999a: 85-87). 
plumas y estiércol de gallinazos en el patio principal del Templo Viejo. En efecto, siguiendo a los excavadores

“(...) limpiezas muy cuidadosas en el centro del patio permitió descubrir las vértebras de peces pequeños impregnados en el piso (...) En otros sectores de excavación en el Templo Viejo se encuentran abundantes plumas de gallinazos; del mismo modo en basurales y entierros humanos disturbados. Muchos sacrificios de camélidos tanto en la cima como en la base del Templo se hallan removidos por la presencia de estas aves" (Paredes \& Franco, 1989a: 3).

Los autores hacen immediatamente la relación con el rito relatado por Pedro Pizarro. Sin embargo, desde el punto de vista cronológico, los elementos mencionados están fechados del siglo $\mathrm{X}$ y corresponderían a una etapa de re-utilización de una parte de las estructuras del templo a consecuencia de la influencia Huari (Paredes \& Franco, 1989a: 76). Estas precisiones, así como el carácter del contexto, invitan a la prudencia. En efecto, durante las excavaciones en Pachacamac, he encontrado muchas veces excrementos, plumas y otros restos de aves locales, particularmente gallinazos, muy numerosos en la zona. Las aves anidaron a menudo en las ruinas y consumieron pescados o roedores, obviamente sin esperar a que los hombres se los proporcionaran... Los huesos y restos de pescados suelen ser abundantes en todos los niveles excavados (Bearez et al., 2003). Podría ser igual para el Templo Viejo: plumas, excrementos y vértebras de peces reflejando simplemente una época de abandono.

De la misma manera, Ravines (1990) propone que el rito haya sido realizado al pie del Templo del Sol. Se basa en el descubrimiento —en una capa de derrumbe- de una cabeza de gallinazo

“(...) cuyas plumas de la nuca, cuidadosamente recogidas, se habían ajustado mediante cuatro vueltas con un hilo de algodón blanco - un copete o borla que al parecer pendía a manera de colo, especie de brocha- de $2 \mathrm{~cm}$ de largo, hecho con hilos delgados de algodón de color blanco" (Ravines, 1990: 31).

Este autor sugiere que el animal pudo vivir cautivo, quizás bajo la vigilancia de los sacerdotes encargados del famoso ritual. Observó que el tratamiento ornamental de la cabeza del ave igual se pudo hacer después de la muerte del animal, con fines de adorno personal u otros.

El rito descrito por Pizarro no encuentra confirmación indiscutible en el registro arqueológico documentado hasta hoy. Agregaré que los autores citados ante todo parecen preocupados por encontrar a todo trance la huella arqueológica de lo que dicen los textos. Al respecto, hay que recordar que el ritual tomado como referencia se remonta a la época de la conquista y se realizaba, según Pedro Pizarro, frente al santuario del ídolo oracular, el cual se encontraba en esta época probablemente en la cima del Templo del Sol ( $c f$. Eeckhout, 1998b). Si se quisiera encontrar huellas de esta ceremonia, lógicamente es en este lugar donde se tendría que empezar a buscarlas.

\section{OFRENDAS}

Existe una gran variedad de prácticas rituales que implican la donación, y/o la destrucción de artefactos o productos orgánicos. También en este caso la etnohistoria suele mostrarse bastante prolija; unos elementos se mencionan de manera recurrente, 
especialmente los espondylus, las semillas de ishpingo y las hojas de coca, todos igualmente presentes en el registro arqueológico.

\section{1. Espondylus}

El espondylus (mullu en quechua) es una concha bivalva de la Familia Spondylidae, que posee dos especies: Spondylus princeps (Broderip, 1833) y Spondylus calcifer (Carpenter, 1856). Entre los incas, se hacían ofrendas de espondylus a las fuentes de agua:

“(...) diciendo que era sacrificio muy a propósito, por ser las fuentes hijas de la mar, que es madre de las aguas; y conforme tenían el color, las ofrecían para diferentes intentos, unas veces enteras, otras muy molidas, otras solamente quebrantadas y partidas, y también, formadas de sus polvos y masas, algunas figuras. Ofrecían estos sacrificios a las dichas fuentes en acabando de sembrar, para que no se sequasen aquel año, sino que corriesen abundantemente y regasen sus sembrados, como lo habían hecho los otros años" (Cobo, 1964[1653], L. 13, cap. 22: 204; 1990[1653]: cap. 22: 117).

Se describen muchos otros usos rituales del espondylus en los testimonios de juicios de idolatrías (Duviols, 1986; Polia, 1999: 118-119). Siguiendo a Lumbreras (1987) la concha se asimilaba a la muerte en la costa Norte, porque se desarrolla en las aguas peruanas durante los fenómenos del Niño, los cuales tienen efectos destructivos sobre la fauna local; por extensión, el espondylus se consideraba como un presagio de destrucción de toda vida, particularmente humana. Opino que Shimada (1994: 238-239) propone una explicación más coherente, pues concuerda con los datos etnohistóricos:

"Though it may take transplanted larvae a few years to grow a recognizable size, their appearance along the Peruvian Coast may have come to be associated with the arrival of heat and abundant water. Ritual offerings of imported spondylus may have thus began as a way of seeking water without destructive El Niño-related torrential rains".

Davidson (1981: 84) estima que las características del espondylus pueden —según los casos - representar la muerte o la vida para la humanidad, aunque los temas principales a los cuales remiten sean las más de las veces la dualidad y la fertilidad. Sugiere que la concha podría representar al cuerpo de Pachacamac (Davidson, 1981: 80), entre otros por su color rojo (21). Arriaga (1999[1621]: 54) explica que a las huacas se les ofrecían cuentas de espinas labradas de mullu (chaquiras). La confesión era una costumbre indígena (Polia 1999: 102) en el curso de la cual se rompían chaquiras con el fin de determinar la sinceridad y el valor de la confesión (Arriaga, 1999[1621]: 57).

La presencia del espondylus en contextos arqueológicos más al sur del quinto paralelo sólo se puede explicar por contactos — directos o indirectos - con las costas ecuatoriales. Las problemáticas relacionadas con la recolección, el intercambio, el negocio, el uso y la simbología del espondylus en los Andes prehispánicos han sucitado diversos ensayos y reflexiones muy interesantes (Cordy-Collins, 1990; 2001b; Davidson, 1981; Murra, 1975: 255-267; Paulsen, 1974; Pillsbury, 1996; Sandweiss, 1992: 141-142; Sandweiss et al., 1991; Shimada, 1991: LI-LIV; 1994: 213-216, 238-239), pero relativamente limitados respecto a la importancia de esta concha en el registro arqueológico.

(21) "El Señorío de Ychma de la costa central derivaba su nombre del color rojo, ya sea del azogue o del achiote, empleado en las ceremonias vinculadas al culto del célebre oráculo yunga" (Rostworowski, 1977: 200). 
En los sitios del Lurín, se hallaron en 13 contextos (Cuadro 7). En las excavaciones el espondylus se encuentra de varias maneras: bien entero, bien usado como materia prima para realizar artefactos (generalmente adornos), o bien fragmentado.

La lectura del Cuadro 7 nos enseña que los espondylus están frecuentemente asociados a los contextos funerarios $\left(n^{\circ} 9, n^{\circ} 12\right)$ o a las ofrendas $\left(n^{\circ} 3, n^{\circ} 4, n^{\circ} 7, n^{\circ} 8\right.$ $\left.\mathrm{y}^{\circ} 13\right)$. Se encuentran desde el fin del Horizonte Medio hasta el periodo Inca inclusive. Los fragmentos forman parte de las ofrendas múltiples, es decir, las que constan de diferentes clases de materiales y/o artefactos $\left(\mathrm{n}^{\circ} \quad 5\right.$, h 10 y h 11). Parece tratarse de una práctica bastante tardía (fin del Intermedio Tardío y Horizonte Tardío).

El polvo de espondylus (o los fragmentos pequeños), a veces acompañado por chakiras, se encuentra en las capas de relleno con material seleccionado $\left(n^{\circ} 1\right.$, h 2 ? y $n^{\circ}$ 6). Dicha costumbre se observa desde el periodo Intermediđemprano hasta el periodo Intermedio Tardío. Se interpreta como el símbolo del carácter ritual de la operación de relleno y - por extensión — del aspecto sagrado del contexto arqueológico en el cual esta operación se llevó a cabo (comp. Keatinge, 1982; Lee Bruce, 1986; Silverman, 1993: 294). Esta interpretación parece aplicarse a Pachacamac, pues en los dos primeros casos, se trata de un edificio con funciones religiosas (el TVP) y en el tercero se trata del relleno constructivo del piso de una plaza ubicada fuera de la pirámide III, una plaza que opino sirvió para agrupaciones puntuales de tipo peregrinaje (Eeckhout, 1995).

En resumen, por lo que concierne al sentido de las prácticas relacionadas con el uso de espondylus, vemos que las fuentes etnohistóricas encuentran eco sólo en el campo funerario.

\section{2. Semillas de ishpingo (Nectandra sp.)}

Arriaga (1999[1621]: 53) explica que:

“(...) el ishpingo es una frutilla seca, al modo de almendras redondillas, de muy vehemente olor, aunque no muy bueno. Traenle de Chechapoyas; dicen que es muy medicinal para dolores de estómago, y cámaras de sangre y otras enfermedades, tomado en polvos, y la compran muy caro (...) y en Jaen de Bracamoros pagaban, no ha muchos años, los indios su tributo en ishpingo".

Efectivamente, Nectandra panamensis mez por ejemplo, se considera antidisentérica (Tico Ethnobotanical Dictionary), y se encuentran en la literatura moderna referencias a su uso medicinal (Webster Dictionary, 2001[1913]). El cronista Cobo (1964[1653], L. 4, cap. 91: 195, L. 6, cap. 90: 272), describiendo el ishpingo en bebidas, señala que "(...) hace no sentir los tormentos, por rigurosos que sean". Deduce Rostworowski (1989: 249) que se trata de un analgésico usado en los rituales por los brujos. Pero Arriaga (1999[1621]: 53) señala otro uso de las mismas semillas:

“... era ordinaria ofrenda para las huacas, especialmente en los llanos, que no hay quien no tenga espinco, teniendo conopa, de todos cuantos se han visitados".

Parte de estas ofrendas tal vez sirvieron para rituales, pues el mismo Arriaga (1999[1621]: 50), describiendo las costumbres de los "ministros de los cultos indígenos", menciona que: 
Cuadro 7 - Excavaciones de Espondylus.

\begin{tabular}{|c|c|c|c|c|c|c|}
\hline & Sitio & Localiz. & Descripción & Contexto & Periodo & Fuente \\
\hline 1 & Pachacamac & TVP & $\begin{array}{l}\text { Cuentas y } \\
\text { fragmentos } \\
\text { cortados }\end{array}$ & $\begin{array}{l}\text { Rellenos } \\
\text { de nivelación }\end{array}$ & PIT? & Franco, 1993b: 52 \\
\hline 2 & Pachacamac & TVP & $\begin{array}{l}\text { Fragmentos } \\
\text { y chakiras }\end{array}$ & $\begin{array}{l}\text { Entre los } \\
\text { desperdicios en } \\
\text { la superficie } \\
\text { del patio }\end{array}$ & HM 3-4? & $\begin{array}{l}\text { Paredes \& } \\
\text { Franco, 1989a: } \\
3,75\end{array}$ \\
\hline 3 & Pachacamac & TVP & Valvas volteadas & $\begin{array}{l}\text { Ofrendas en un } \\
\text { recinto pequeño }\end{array}$ & HM 3-4 & $\begin{array}{l}\text { Franco \& Paredes, } \\
\text { 2000: 615; } \\
\text { Paredes \& Franco, } \\
\text { 1989a: } 9\end{array}$ \\
\hline 4 & Pachacamac & TVP & $\begin{array}{l}106 \text { valvas } \\
\text { (algunas } \\
\text { pintadas) }\end{array}$ & $\begin{array}{l}\text { Ofrendas en un } \\
\text { recinto pequeño }\end{array}$ & $\begin{array}{l}\text { HM 3-4 } \\
\text { o PIT }\end{array}$ & $\begin{array}{l}\text { Franco, 1993b: 54; } \\
\text { Franco, 1993a: 61 } \\
\text { Franco \& Paredes, } \\
\text { 2000: 613; } \\
\text { Paredes \& Franco, } \\
\text { 1989a:13, } 75\end{array}$ \\
\hline 5 & Pachacamac & $\begin{array}{l}\text { Pirámide } \\
\mathrm{N}^{\circ} \mathrm{III}\end{array}$ & Un fragmento & Ofrenda múltiple & PIT o HT & $\begin{array}{l}\text { Eeckhout, } \\
\text { 1998c:176-181 }\end{array}$ \\
\hline 6 & Pachacamac & $\begin{array}{l}\text { Pirámide } \\
\mathrm{N}^{\circ} \mathrm{III}\end{array}$ & Un fragmento & $\begin{array}{l}\text { Relleno } \\
\text { constructivo }\end{array}$ & PIT6/7 & $\begin{array}{l}\text { Eeckhout, } \\
\text { 1999a: } 134\end{array}$ \\
\hline 7 & Pachacamac & $\begin{array}{l}\text { Pirámide } \\
\mathrm{N}^{\circ} \mathrm{III}\end{array}$ & $\begin{array}{l}\text { Dos valvas } \\
\text { enrolladas en } \\
\text { un textil }\end{array}$ & $\begin{array}{l}\text { Ofrenda de } \\
\text { abandono }\end{array}$ & PIT8 & $\begin{array}{l}\text { Eeckhout \& } \\
\text { Farfán, 2000: } 111\end{array}$ \\
\hline 8 & Pachacamac & $\begin{array}{l}\text { Pirámide } \\
\mathrm{N}^{\circ} \mathrm{II}\end{array}$ & $\begin{array}{l}\text { Fragmentos, } \\
\text { espinas y } \\
\text { valvas enteras }\end{array}$ & $\begin{array}{l}\text { Capas } \\
\text { superficiales }\end{array}$ & HT & $\begin{array}{l}\text { Franco, } \\
\text { 1998: } 66 \text { \& App.1 }\end{array}$ \\
\hline 9 & Pachacamac & $\begin{array}{l}\text { Pirámide } \\
\mathrm{N}^{\circ} \text { III }\end{array}$ & $\begin{array}{l}\text { Valvas y } \\
\text { chakiras }\end{array}$ & $\begin{array}{l}\text { Contexto funerario } \\
\text { saqueado }\end{array}$ & HT & $\begin{array}{l}\text { Eeckhout } \\
\text { \& Farfan, 2001: } \\
\text { 101-109 }\end{array}$ \\
\hline & Pachacamac & TVP & $\begin{array}{l}\text { Espondylus } \\
\text { molido }\end{array}$ & $\begin{array}{l}\text { Dentro de un } \\
\text { manto inca }\end{array}$ & HT & $\begin{array}{l}\text { Franco \& } \\
\text { Paredes, 2000: } 616\end{array}$ \\
\hline & $\begin{array}{l}\text { Pampa } \\
\text { de Flores }\end{array}$ & Cementerio & Fragmentos & Ofrenda múltiple & PIT7 & $\begin{array}{l}\text { Eeckhout, 1998c: } \\
\text { 201-206 }\end{array}$ \\
\hline 12 & $\begin{array}{l}\text { Pampa } \\
\text { de Flores }\end{array}$ & Cementerio & 3 valvas & $\begin{array}{l}\text { Fardo de } \\
\text { mujer adulta }\end{array}$ & $\begin{array}{l}\text { Posterior } \\
\text { al PIT. 5B }\end{array}$ & $\begin{array}{l}\text { Eeckhout, 1999a: } \\
\text { 361-362 }\end{array}$ \\
\hline 13 & Tijerales B & $\begin{array}{l}\text { Pirámide } \\
\text { Norte }\end{array}$ & 4 valvas & Ofrenda múltiple & $\begin{array}{l}\text { Posterior } \\
\text { al PIT. 5B }\end{array}$ & $\begin{array}{l}\text { Eeckhout, 1998c: } \\
\text { 213-215; } \\
\text { Eeckhout, 1999a: } \\
296\end{array}$ \\
\hline
\end{tabular}


"En los llanos desde Chancay abajo la chicha que ofrecen a las huacas se llama yale, y se hace de zora mezclada con maíz mascado y le echan polvos de ishpingo; hácenla muy fuerte y espesa, y después de haber echado sobre la huaca lo que les parece, beben la demas los hechiceros, y les vuelve como locos".

Sea por la mezcla con alcohol o por las mismas cantidades que ingerían, parece que el ishpingo tiene también propiedades psicotrópicas. Cobo (1964[1653], L. 6, cap. 90: 272) menciona también que la sustancia de ishpingo, "cuajada, es como sangre de drago, aunque reluciente y tirante a negra, y de suave y profundo olor". Volveré sobre estos datos, pero podemos ya constatar que el ishpingo descrito por los cronistas tenía gran importancia en la costa, tanto por sus cualidades medicinales como por sus efectos psicoactivos.

Un elemento recurrente en las ofrendas Ychsma descubiertas en las excavaciones es la presencia de semillas ovaladas de color marrón de 1 a $2 \mathrm{~cm}$, cortadas en dos mitades en sentido longitudinal, oradadas con un hueco en su centro (Fig. 6). Se encontraron en número variable en numerosos contextos arqueológicos de Pachacamac y del valle de Lurín (Eeckhout, 1998c; 1999a; 2001).

Intervienen en ciertos ritos funerarios así como en la constitución de ofrendas generalmente asociadas con los difuntos. El análisis botánico indica que se trata de semillas de ishpingo (Nectandra sp.). Dichas semillas también se conocen bajo el nombre de amala y son bastante frecuentes en los contextos de ofrenda de la costa norte y central del Perú desde el periodo Intermedio Tardío hasta el Horizonte Tardío (ver Baessler, 1902-1903: T. 474; Kaulicke, 1983: Abb. 68, fig. 30; Montoya, 1996; 1998; 1999; Narváez, 1995: 107; Topic, 1982: 160; Towle, 1961: 40). Es muy probable que estas semillas tuvieran un valor simbólico - hasta ritual-importante. Basándose en análisis fitoquímicos, Montoya (1998: 11; 1999: 15-16) avanza que Nectandra sp. tiene propiedades analgésicas, psicotrópicas y hasta mortales (según la dosis absorbida). En Pachacamac, está la mayoría de las veces ligado a las prácticas funerarias, más específicamente a procesos de enfardelamiento, sin duda por causa del olor fuerte que desprenden las semillas, como lo expliqué detalladamente en otra oportunidad (Eeckhout, 2001).

\section{3. Coca}

La coca (Erythroxilon coca) representaba una de las ofrendas más difundidas en el Imperio Inca (Rowe, 1946: 297, 304, 311-313). Generalmente se quemaba y a veces se enterraba bajo tierra (Rowe, 1946: 248, 292, 303, 307, 311). En la región que nos interesa, un proceso de extirpación fechado en el año 1704 explica que:

"Esta costumbre estaba muy difundida entre los yungas, dejando a lado otras, es decir la de sepultar en la tierra las hojas de aquella plantita, me refiero a la tierra que llaman Pachamama, que se traduce grande Madre con el propósito que por la coca que han esparcido, agradeciéndolos, responda con abundancia de mieses" (Polia, 1999: 558).

En Duviols (1986) la mayoría de las muy numerosas menciones de uso de coca se relacionan con la cremación de las hojas en honor a los mallquis (cuerpos momificados de ancestros difuntos). En el valle de Lurín la clase de ofrendas prescritas por Pariacaca a beneficio de su hijo Chuquihuampo es reveladora:

"Toda la población de estos dos valles te traerá las primicias de sus cosechas de coca antes que alguien la haya probado; soló cuando tú la haya probado, la gente podrá mascar 


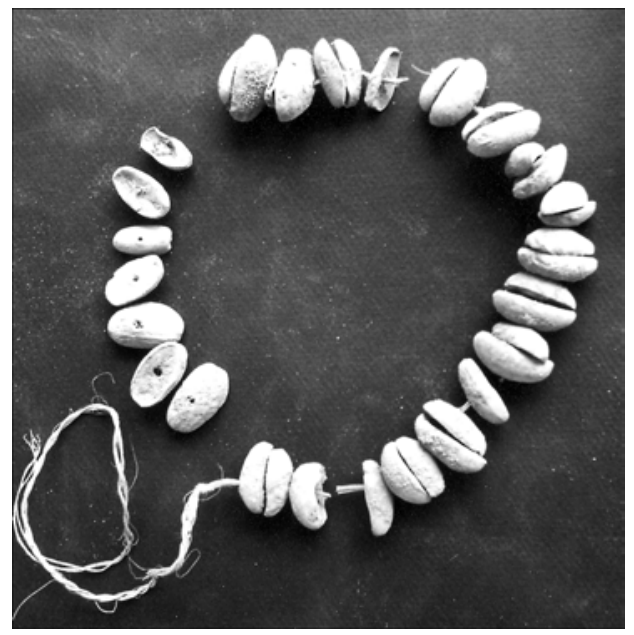

Fig. 6 - Sarta de ishpingos hallada en ofrenda en un escondrijo. Pirámide III, Pachacamac (temporada 1999).

la coca de sus plantaciones (...)Respentando a sus instrucciones, todos los dueños de cocales de Sacicaya (22), de Chontay (23), de Chichima (24), de Mama (25), de Huayocalla le traían las primicias de sus cosechas" (Taylor, 1987, cap. 8: 159).

La coca aparece reiteradamente en los contextos de ofrendas, a menudo bajo la forma de hojas pequeñas llamadas coca kinto. Se trata de las mejores hojas de la variedad conocida bajo el nombre quechua de tupa coca (Erytroxylon novogranatense trujillensis) usada en los rituales (Rostworowski, 1989: 250; 1992: 101).

Se debe mencionar dos ofrendas específicas de coca. La primera, hallada en Pampa de las Flores, parece asociarse a rituales funerarios o post-funerarios (Eeckhout, 1998c: 201-206). La segunda, descubierta en el Templo del Mono en Pachacamac, se encontraba dentro de una fosa de $20 \mathrm{~cm}$ de diámetro que contenía otras dos ofrendas (restos de cuyes, ishpingos, textiles miniatura), así como los restos de un poste tallado cuadrangular (Eeckhout \& Farfán, 2001: 94). La disposición del poste, frente a un acceso, así como la cantidad importante de sobras de rituales alrededor, sugieren que se trata de una ofrenda de fundación hecha al momento de colocar el poste — tal vez el pedestal de algún ídolo- - $c f$. Eeckhout, 2001; 2002a, Eeckhout \& Farfan, 2001: 91-97). Solo la primera ofrenda se puede relacionar con las fuentes etnohistóricas en base a la vinculación con los ancestros y las ceremonias funerarias. El segundo contexto no encuentra paralelo en los textos que tuve oportunidad de consultar.

(22) Sacicaya es un asentamiento prehispánico ubicado en el margen derecho del río Lurín, a unos 900 m de altitud (ver Eeckhout, 1999a; Feltham, 1983).

(23) Chontay es un asentamiento prehispánico ubicado en el margen izquierdo del río Lurín, a unos $700 \mathrm{~m}$ de altitud (ver Eeckhout, 1999a; Feltham, 1983).

(24) ¿Ychsma?

(25) Mama es un asentamiento prehispánico ubicado en el margen izquierdo del río Rímac, a unos 900 m de altitud (ver Spalding, 1984; Patterson, 1992). 


\section{4. Otras ofrendas}

Por supuesto la chicha tiene un rango principal dentro de los objetos citados más habitualmente como parte de ofrendas y son escasas las ceremonias donde no juega algún papel (Arriaga, 1999[1621]: 50, 70; Avila, 1980[1608?]: 65; Duviols, 1986; Polia, 1999: 110; Rowe, 1946: 306). Esta bebida se consumía generalemente entre los participantes, mientras parte se echaba al suelo.

En las excavaciones, se observan con mucha frecuencia las huellas que pudieron dejar este tipo de actividades. Se presentan bajo la forma de manchas blanquecinas, producto de la fermentación del líquido que impregna los textiles, las ofrendas, el fondo de ciertas vasijas y a veces hasta las paredes de los muros al pie de los cuales se enterraron las ofrendas.

El ingrediente básico de la chicha - el maíz - constituía también una ofrenda recurrente. Arriaga (1999[1621]: 38) señala, por ejemplo, que se conservaban en los depósitos de maíz las mazorcas particularmente coloradas con el fin de favorecer las cosechas. Durante la temporada 2000 en Pachacamac, una ofrenda parecida a esta descripción se encontró en un recinto que tenía todas las características de un depósito (Fig. 7).

Numerosas plantas están citadas en las fuentes escritas (Polia, 1999: 137-144), entre otras, por ejemplo, la huaman ripa (Laccopetalum giganteum), una hierba con virtudes purgativas. Varios contextos descubiertos en los asentamientos de elite de Lurín constan de diferentes especies de cultígenos y vegetales. Podrían ser ofrendas propiciatorias para favorecer las cosechas.

En el área de estudio, al igual que en el resto de los Andes prehispánicos, el textil ocupa un lugar de primera importancia entre las ofrendas de objetos manufacturados (Arriaga, 1999[1621]: 80-81; Polia, 1999: 118; Rowe, 1946: 307). Generalmente se trata de vestidos finos, tamaño natural o miniaturas, la mayoría de las veces quemados en honor a las huacas o destinados a vestir los ancestros momificados y a ciertos ídolos (Cobo,

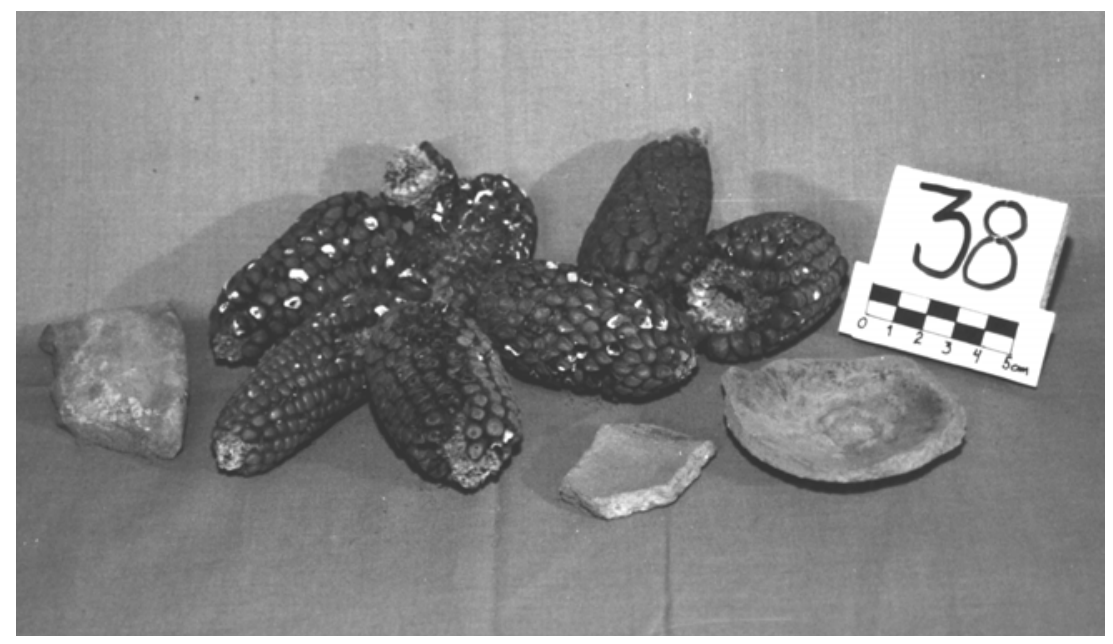

Fig. 7 - Mazorcas de maíz, fragmentos de mate y tiestos encontrados en un escondrijo en un depósito. Pachacamac, Pirámide III (temporada 2000). 
1990[1653], I, cap. 22: 117). Los vestidos llevados antes de ciertos ritos de purificación eran abandonados en el mismo lugar (Arriaga, 1999[1621]: 58).

Arriaga (1999[1621]: 51-60) menciona una serie de ofrendas diversas de plata (adornos en forma de media luna), de plumas (unas como adorno de vestidos o tocados) o bajo la forma de polvos de colores. Los destinatarios siempre son los ancestros o las huacas, pero por lo general las motivaciones precisas desafortunadamente no despertaron el interés de los extirpadores, los cuales se contentan con explicarlas con razones muy generales ligadas a los campos de la agricultura, del clima, así como de los rituales de adivinación y de "confesiones", como se ha visto más anteriormente en este ensayo.

Los textiles representan una categoría de ofrendas importantes — sin embargo escasamente evocada - del registro arqueológico. En primera fila están las miniaturas (Fleming et al., 1983; Franco, 1993a: 68). Numerosos ejemplos se recuperaron en el curso de las excavaciones llevadas a cabo en la pirámide III de Pachacamac (Eeckhout \& Farfán, 2000; 2001; Feltham, 2002: 104, fig. 9), pero todavía estaban en proceso de estudio al momento de escribir estas líneas. Señalo simplemente que, por lo que concierne a su contexto y su aspecto general, estas ofrendas comparten las mismas características: (1) los vestidos miniatura siempre están enrollados sobre sí mismos, a veces anudados; (2) no se encuentran solos, sino en grupos de varios ejemplares; (3) están asociados a conjuntos funerarios o con capas de abandono voluntario. Estas dos últimas características también son comunes en algunos ejemplos de ofrendas de vestidos miniaturas de metal (Eeckhout, 1998c). También en estos casos, el contexto probablemente se relaciona con el culto a los ancestros - lo que confirma las fuentes escritas - sin que se pueda decir mucho más, salvo que la práctica es anterior a la conquista Inca y consecuentemente es posible que se tratara originalmente de una práctica costeña adoptada por los incas ( $c f$. Eeckhout, 2002b).

El primer corte de pelo constituía un rito importante (Arriaga, 1999[1621]: 65; Morote Best, 1988: 300-310) que según Cieza de León (1995[1551], I, cap. 65: 200) se llevaba a cabo cuando se le daba su nombre definitivo a los niños, alrededor de los 10 ó 12 años de edad; los cabellos cortados se conservaban cuidadosamente (Cieza de León, 1995[1551], I, cap. 65: 201; Arriaga, 1999[1621]: 65,130). Un documento del año 1617 respecto a una extirpación en la zona de La Barranca-Cajatambo explica que se ofrecían a una huaca cabellos de niños, especialmente los ensortijados o los que presentaban alguna particularidad (Polia, 1999: 391). Avila (1980[1608?]: 227 \& ss.) describe detalladamente el mismo tipo de ceremonia entre los checas de San Damián (Huarochirí). Pariacaca y Tutayquiri (un ancestro famoso) son considerados como responsables de esta conformación particular de la cabellera, y la ceremonia se dedica a ellos (Avila, 1980[1608?]: 227 \& ss.). Cieza de León (1995[1551], I, cap. 63: 197) y Cobo (1964[1653], L. 14, cap. 19: 274; 1990[1653], cap. 19: 250) mencionan que a la muerte de un señor, sus mujeres se cortaban el pelo en señal de duelo. Como parte del cuerpo humano, sugiere Polia (1999: 117), los cabellos participaban de la energía específica de una persona y pues, podían servir de sustitutos en una serie de prácticas rituales: ofrendas, magia amorosa, hechizos, etc. Entre los otros elementos recurrentes en las ofrendas figuran también las pestañas (Arriaga, 1999[1621]: 54).

Los pelos y mechones de cabellos son bastante frecuentes en los contextos de ofrenda (Fig. 8). Es posible que en ciertos casos dichas ofrendas correspondan a las ceremonias de corte de pelo descritas en los textos, pero en la mayoría de los casos parece tratarse de 


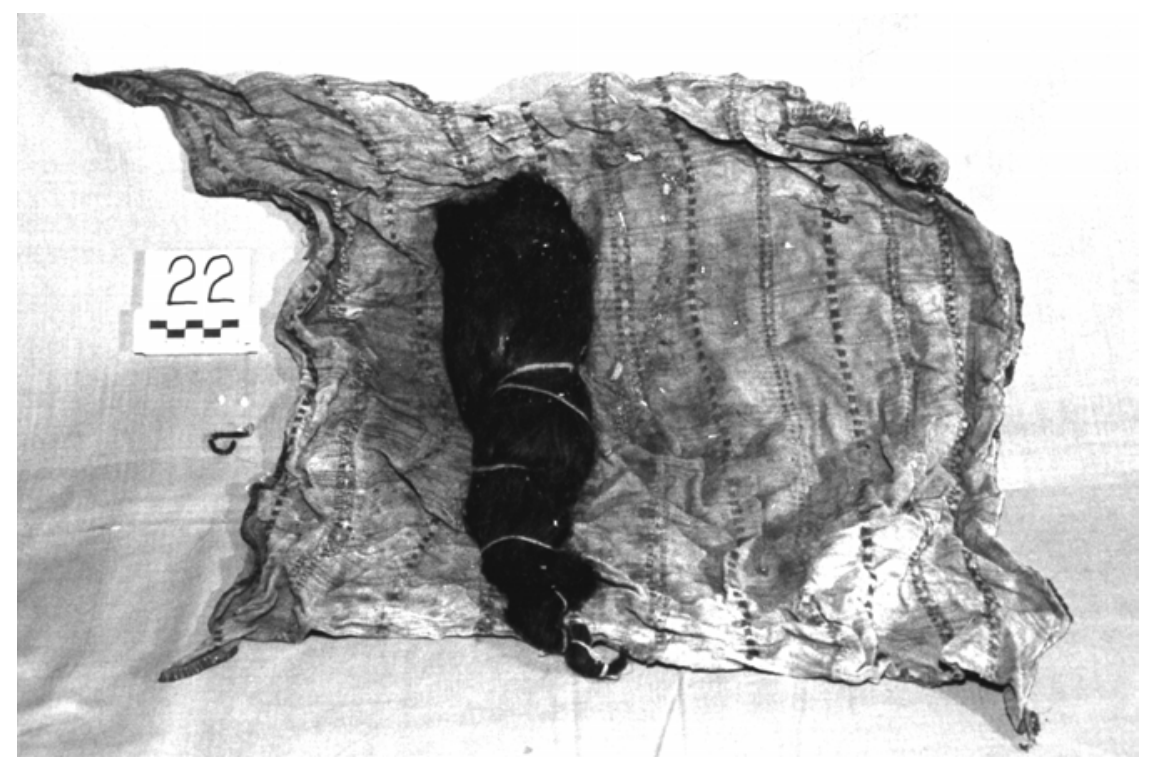

\section{Fig. 8 - Mechón de cabellos enrollado en un textil decorado encontrado en un escondrijo de ofrenda (probablemente Horizonte Tardío). Pachacamac, Pirámide III (temporada 2000).}

cabellos de adulto y los contextos nunca están muy lejos de las tumbas, lo que hace más probable la costumbre de duelo ( $c f$. Eeckhout, 1998c).

Entre las otras ofrendas descubiertas en excavaciones hay un buen número de objetos valiosos, de metal, de tejidos, hasta de plumas (Eeckhout, 1998c). Otros artefactos son más difíciles de clasificar, como por ejemplo estas cinco gavillas de 10 junquillos cilíndricos asociadas con el entierro ritual de una fase antigua de la pirámide con rampa III de Pachacamac (Fig. 9 comp. Silverman, 1993: 181, fig. 13. 37). En fin, existen ofrendas únicas o específicas tales como este escondite del Templo Viejo de Pachacamac conteniendo un manto inca polícromo y estatuillas de oro ( $c f$. Bray, 1990; Franco, 1993b: 61; Paredes \& Franco, 1989a: 12-13). Siguiendo a Paredes \& Franco, esta ofrenda habría sido hecha en el marco de una capac hucha. En el mismo edificio, un escondrijo fechado en la segunda mitad del Horizonte Medio contenía una serie de 145 vasijas decoradas, rotas de forma voluntaria (Franco \& Paredes, 2000). Franco (1993b: 57-59) estima que se podría tratar de una conmemoración de la remodelación del templo en dicha época. Otro escondite de cerámicas rotas - algunas todavía enteras - fechado en el periodo Intermedio Tardío, ha sido sacado a la luz al pie del "Portal del Valle", en la tercera muralla que marca el límite del perímetro arqueológico del sitio de Pachacamac (Paredes \& Ramos, 1994). Los autores piensan que se trata de ofrendas dejadas por peregrinos.

\section{PEREGRINAJE}

Como mencioné en la introducción, el peregrinaje a larga escala hasta Pachacamac está ampliamente documentado por las fuentes etnohistóricas. La corta descripción de Pachacamac proporcionada por Hernando Pizarro (1872[1533]: 122- 


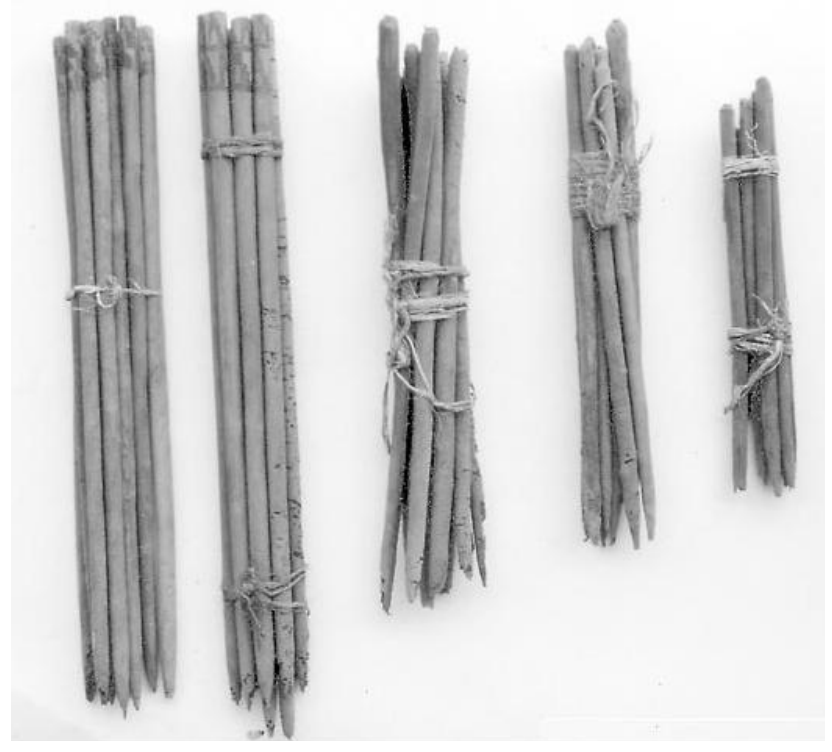

Fig. 9 - Ejemplo de ofrenda: cinco gavillas de diez junquillos cilíndricos (L: de 41 a $26 \mathrm{~cm}$ ). Pachacamac, Pirámide III (temporada 1995).

123) empieza con explicaciones respecto a esta costumbre. La influencia del templo fue importante. Entre otras cosas se traducía en el hecho de que en varios lugares existían santuarios relacionados con el dios por vínculos familiares míticos. Por ejemplo, Davila Brizeño (1881[1586]: 163) cita el caso del pueblo de Mama, en el valle de Rímac, donde se encontraba un templo dedicado a la esposa de Pachacamac. Se trataría de Manañamca (Espinoza, 1984: 181). Con mucha razón Rostworowski (1977: 202) hace notar que la zona de Mama se ubica en un piso ecológico importante - la zona chaupiyunga - donde se podía cultivar la coca (muy apreciada para rituales y ofrendas), que no crece en la costa. Urpayhuachac, la esposa de Pachacamac, también tenía una isla a su nombre, huaca de los pescadores de Chincha (Albornoz, 1967: 34). En el pueblo de San Francisco de Mangas (Cajatambo), los ayllus Chamas y Nanis adoraban a la misma diosa bajo la forma de una paloma de hueso (?) a la cual hacían ofrendas para la lluvia: pequeñas hojas de oro y plata, chaquiras y espondylus (Rostworowski, 1981: 126; 1989: 74). Las fuentes hablan de un hijo de la diosa, llamado Auca Atama, venerado en el mismo santuario de Cajatambo como divinidad de la fecundidad y fertilidad (Rostworowski, 1981: 126-127). Albornoz (1967: 34) menciona a un cierto Sulcavilca, huaca principal de los indios de Lunahuana (Mala), hermano de Pachacamac; se trataba de un cerro en la orilla del mar (Fig. 10). Santillán (1879[1551]: 33) habla de los cuatro hijos de Pachacamac y de las "casas" que les fueron dedicadas en diferentes lugares: Mala, Chincha y Andahuaylas cerca del Cuzco. El cuarto hijo acompañaba al Inca Topa Yupanqui, conquistador de Pachacamac y le servía de oráculo personal. También explica que estas "casas" se multiplicaban y se diversificaban en huacas particulares (para la fertilidad, la fecundidad, la lluvia, etc.), todas procedentes "del Demonio, que por ellas les hablaba" (Santillán, 1879[1551]: 33). 


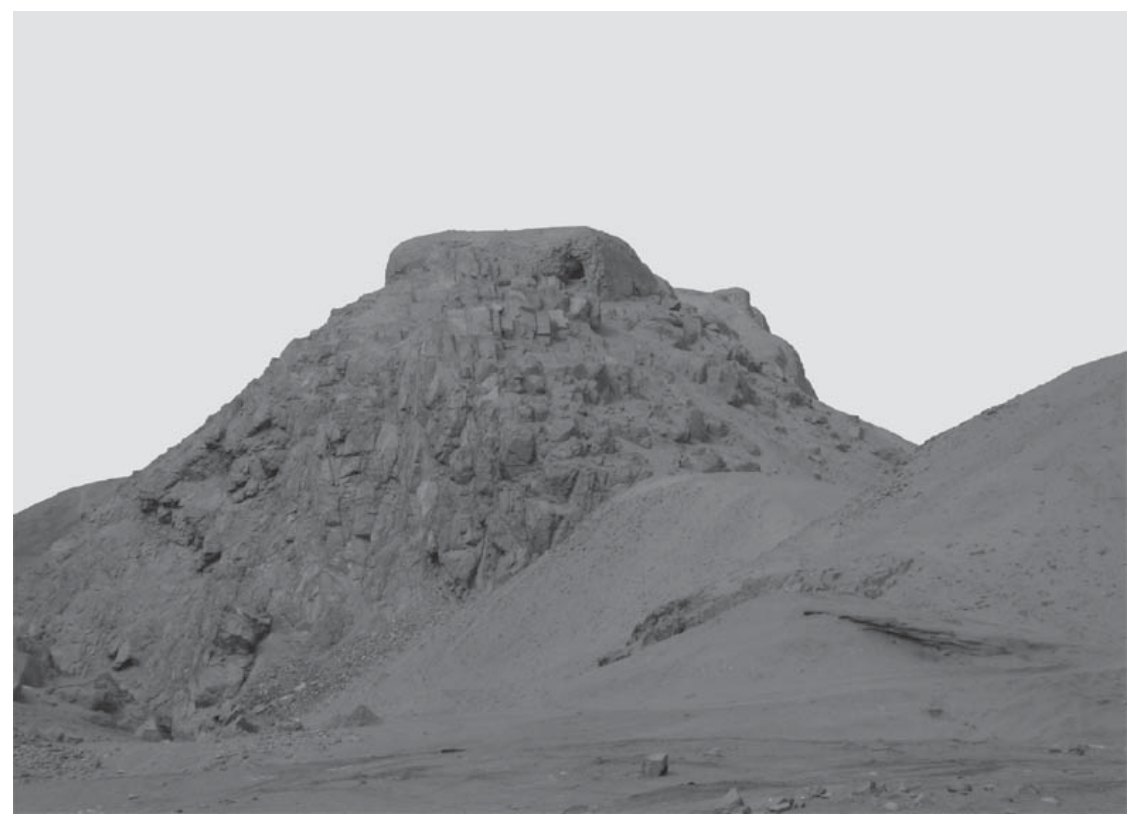

Fig. 10 - Vista del probable santuario de Sulcavilca en El Salitre, desembocadura del río Mala.

Los chincha veneraban un oráculo inspirado en el de Pachacamac que llamaban Chincha Camac (Albornoz,1967: 34; Cieza de León, 1995[1551]: cap. LXXIV seguido por Garcilaso de la Vega, 1991[1609]: 364, 366). Quizás se trata de uno de los hijos de Pachacamac mencionados por Santillán (Patterson, 1992: 89; Rostworowski, 1992: 52). A Llocllahuancupa lo adoraban los ayllus yauyos que iban cada uno a su turno a su santuario en noches de luna llena (Rostworowski, 1992: 52). Le dedicaban también una fiesta especial, Chayana, es decir, "inicio de la estación de lluvias" en la sierra y vestían ricamente a su ídolo en esta ocasión. Chayana tal vez se celebraba en Pachacamac, en diciembre, conforme al calendario lunar (Rostworowski, 1992: 5254). Avila (1980[1608?]: cap. 20) menciona un episodio revelador respecto al culto; explica que los checa (un grupo yauyos) habían dejado de honrar regularmente a su huaca Llocllahuancupa y que ésta, pues, les abandonó a su destino. Para volver a congraciarse con la huaca, se fueron a Pachacamac con ofrendas de llamas y chicha. Cerca a Huarochirí, a inicios del siglo XVII, Avila y sus secuaces descubrieron un templo donde siete divinidades diferentes eran veneradas bajo la forma de piedras grandes; una de ellas representaba a Pachacamac (Polia, 1999: 304-305).

Las manipulaciones incas de los mitos locales llevan a cuestionar la profundidad temporal de la vinculación entre Pachacamac y las varias huacas mencionadas. La índole de la intervención inca es sumamente importante para este asunto y se encuentra en el centro del problema de la difusión del culto y sus ramificaciones. En efecto, cuando Santillán (1879[1551]: 33) habla de los hijos de Pachacamac y de las casas que el Inca les hizo construir (ver arriba), podemos con razón preguntarnos si toda la parentela mítica y los santuarios supuestamente relacionados no podrían simplemente ser una fachada del expansionismo Inca ( $c f$. Patterson, 1983: 167-169; 1992: 90-91; 
Spalding, 1984: 98-101). Además, hay que remarcar que todas las fuentes subrayan la popularidad de Pachacamac pero ninguna indica explícitamente que dicha popularidad se tradujera en otras cosas que la reivindicación de la pertenencia de alguna huaca a la familia del gran dios creador: algo del prestigio de este último que uno se arrogaría teniendo como huaca su hijo, su hermano, o su esposa (26), hasta su mismo doble. Sólo es en casos graves o excepcionales, como el relatado por Avila, es cuando se encuentra mención de una delegación mandada a Pachacamac con regalos.

Por lo que concierne al peregrinaje propiamente dicho, los datos arqueológicos concuerdan con los dichos por Pizarro, entre otros, para lo de las funciones de la serie de grandes patios del barrio A, designado como Plaza de los Peregrinos por Ühle (1903) (Fig. 11). Los elementos disponibles subrayan la intensidad y extensión de la ocupación del Horizonte Tardío, una ocupación cuya índole y distribución concuerdan de manera muy plausible con el peregrinaje a gran escala. A la inversa, cuando uno compara este hecho con la situación en el periodo Intermedio Tardío, parece que el peregrinaje no puede estar atestiguado de manera tan clara antes de la incorporación de Pachacamac en el Imperio Inca (Eeckhout, 2004). En efecto, la argumentación usada por los autores que sostienen la idea de un peregrinaje masivo desde regiones lejanas durante el periodo Intermedio Tardío descansa esencialmente sobre el modelo de las embajadas, según el cual cada pirámide con rampa del sitio es una especie de lugar para acoger a los peregrinos foráneos. Ahora bien, el exámen cuidadoso de este modelo puso en evidencia numerosas carencias y contradicciones (Eeckhout, 1999a; 1999-2000). La idea misma

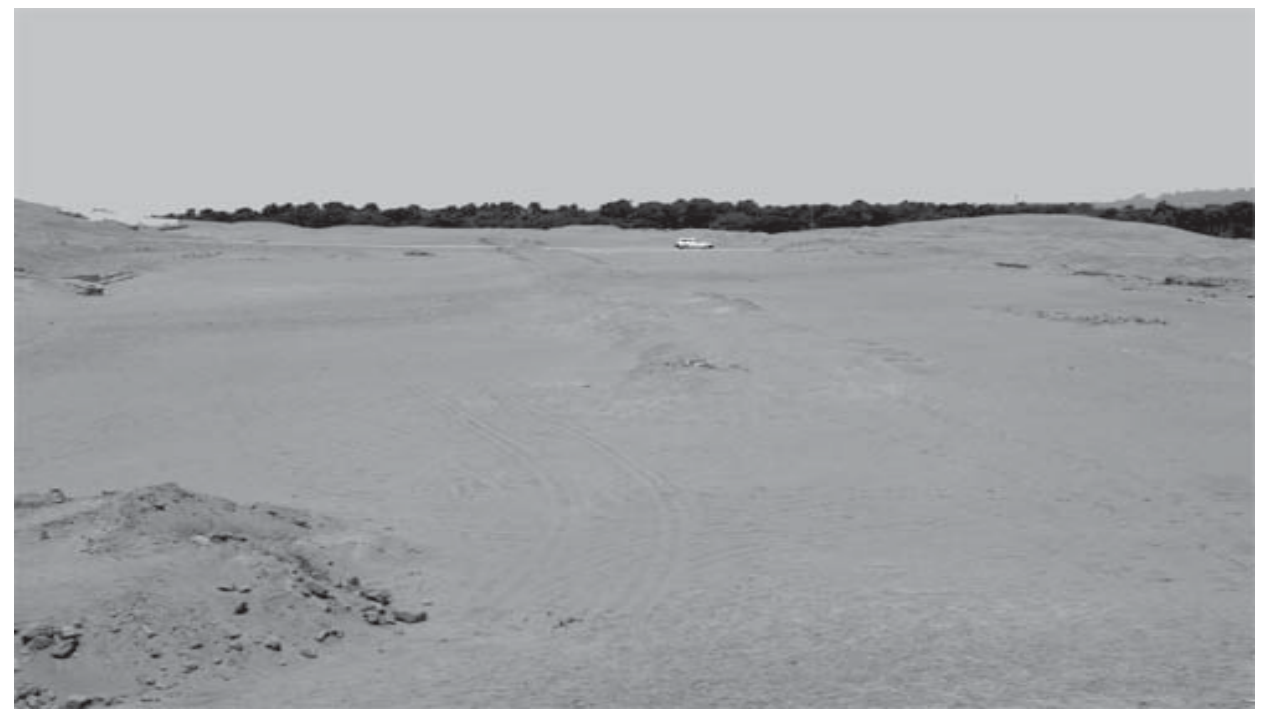

Fig. 11 - Vista de la Plaza de los Peregrinos desde el Este.

(26) La existencia de una parentela mítica asociada a una divinidad renombrada es un fenómeno común en los Andes tal como lo atestiguan, por ejemplo, las múltiples huacas parientes de Pariacaca, dios serrano de la sierra central ( $c f$. Avila, 1980[1608?] analizados entre otros por Alaperrine-Bouyer, 1987; Kemper Columbus, 1992; Salomon \& Urioste 1991; Spalding, 1984; Taylor en Avila 1980[1608?]; Trimborn, 1953). 
de un peregrinaje pan-regional arrastrando muchedumbres a Pachacamac debe ser cuestionada. En el marco de este amplio problema, lo esencial es aclarar la confusión frecuente entre la importancia religiosa y simbólica innegable del Templo de Pachacamac por un lado, y el papel político-económico que se le ha querido atribuir por otro lado. En otros términos, existen dentro del sitio monumental de Pachacamac dos zonas funcionalmente distintas: el Recinto Sagrado, centro del culto, y la Segunda Muralla, lugar de residencia de los jefes ychsma. La confusión mencionada radica en el hecho de que ambas zonas se consideraron estrechamente ligadas a todos niveles, mientras que objetivamente sólo les une su proximidad. Efectivamente, desde el punto de vista arquitectónico, los edificios de una y otra zona no tienen nada en común, ni la índole de las ocupaciones (religiosa y funeraria en la primera, doméstica y residencial en la segunda), ni las pinturas murales (omnipresentes en la primera, totalmente ausentes en la segunda), los artefactos (objetos exóticos y lujosos abundantes en la primera, producción local corriente predominando en la segunda), etc. Importa pues diferenciar el poder político de los líderes ychsma y la influencia religiosa del culto. El marco sociopolítico y la estructura del poder Ychsma han sido descritos en otros lugares (Eeckhout, 1999a; 2003). El aura sagrada de la divinidad merece unas líneas, pues permite explicar de qué manera el centro ceremonial del Recinto Sagrado pudo constituir un foco de atracción regional para los "peregrinos" del periodo Intermedio Tardío. Constatamos que la mayoría de los santuarios dedicados a huacas parientes de Ychsma se ubican en la región cercana (la costa y la sierra central), y que ningún dominio político o control económico parece asociarse a este vínculo de parentela, tampoco la costumbres de "romerías" regulares hasta el sitio principal. No se trata aquí de negar la existencia de dicha costumbre — atestiguada por ejemplo en la variedad de los estilos importados presentes en las tumbas del Cementerio I del Recinto Sagrado ( $c f$. Ühle, 1903, L. VI-X)—, sino más bien devolverle su tamaño real. Pues todo indica que el peregrinaje pan-andino atestiguado en las crónicas participa de la estrategia imperial de dominación e integración de los diversos pueblos y etnias del Tahuantinsuyu. Ese cambio en las peregrinaciones desde el nivel local al inter-regional se aprecia en Pachacamac por el incremento espectacular de las instalaciones de peregrinaje. Durante el periodo Intermedio Tardío, los peregrinos se juntaban probablemente en la Sala $n^{\circ} 26$, al final de la calle Norte-Sur que atraviesa el sitio. Durante el Horizonte Tardío, los incas construyeron la Plaza de los Peregrinos, un complejo de patios de 5 hectaréas con columnas, donde los peregrinos tenían que esperar un año entero antes de ingresar en el Recinto Sagrado y consultar al Oráculo. La Plaza de los Peregrinos es 20 veces más grande que la Sala n 26.

En suma, el "peregrinaje a Pachacamac", si bien existía en el periodo Intermedio Tardío, tenía tal vez un carácter local y relativamente restringido. No significa que nunca hubo peregrinos foráneos, pero estas visitas lejanas se hacían a una escala mucho más pequeña de lo que se observará más tarde.

\section{ADIVINACIÓN}

"Hay en esa mezquita [la de Pachacamac] un ídolo general común a todos, y hay un sabio famoso que tiene la carga de esa mezquita, y los indios creen que él detiene el conocimiento de los eventos futuros, porque él habla con ese ídolo" (Jerez 1965[1534]: 67).

Es en esos términos que el mismo Atahualpa, último emperador Inca en todo el sentido de la palabra, explica a Hernando Pizarro, primer europeo que llegó a Pachacamac, la razón de la popularidad del dios. 
No se debe pensar que la realización de una consulta al dios era tarea sencilla. Al pie del templo se hallaban tres patios grandes que se acercaban progresivamente al santuario. Hernando Pizarro explica —en una carta enviada al virrey en el año1533 que antes de ingresar en el primer patio de la "mezquita", el visitante debía esperar durante veinte días, y antes de acceder al patio superior, nada menos que un año (27).

"In this upper court the bishop used to be. When messengers of the chiefs, who had fasted for a year, went up to pray to God that he would give them a good harvest, they found the bishop seated with his head covered (...). When these messengers of the chiefs delivered their messages to the bishop, the pages of the devil went into a chamber, where they said that he speaks to them; and that devil said that he was enraged with the chiefs, with the sacrifices they had to offer, and with the presents they wish to bring " (H. Pizarro, 1872[1533]: 123).

Sobre el ídolo a través del cual el dios se comunicaba con los hombres, Jerez, (1965[1534]: 96) explica que éstos "le tenían en tanta adoración que sólo sus sacerdotes y los dependientes designados le servían, y los otros no se atrevían a ingresar, y no había nadie suficientamente digno para tocar con su mano los muros de su casa". Parece que esta tradición procede de una regla general respecto a las santuarios mayores:

“(...) no todos los indios ven la huaca principal, ni entran al sitio ni casa donde la huaca está, sino sólo los hechiceros, que hablan con ella, y la llevan las ofrendas" (Arriaga, 1999[1621]: 61).

Los adivinadores (huatuc) tenían que permanecer solteros durante su oficio, se vestían de colores oscuros y permanecían la mayor parte del tiempo en los templos donde recibían los oráculos (Valera, 1968[1585-1589]: 164).

"Se dice - y esto se tiene por fuente cierta - que en este templo el demonio hablaba bajo una forma visible, dando repuestas por su oráculo, y a veces se veía una serpiente cubierta con colores (...). Los hechiceros y ministros infieles consultaban a sus dioses conforme a la enseñanza del demonio. Generalmente ocurría de noche; entraban andando hacia atrás, dandole la espalda al ídolo e, inclinándose y bajando la cabeza, tomaban una posición fea y así consultaban. Usualmente, la repuesta fue una especie de silbido atroz o gemido que les horrorizaba (...)" (Acosta, 1979[1589]: 254).

“(...) Al tiempo de oír el oráculo, se tomaba el tal ministro de un furor diabólico que ellos decían utirayay, y después declaraba al pueblo lo que el oráculo le había dicho (...) Tal fue el oráculo (...) de Pachacamac" (Valera, 1968[1585-1589]: 164).

Arriaga (1920[1621]: 37) afirma que los “ministros mayores" se emborrachaban con chicha cuando querían hablar con las huacas. Albornoz (1967: 27) y Cobo (1964[1653], L. 13, cap. 36: 230; 1990[1653], cap. 36: 169) agregan que mezclaban la chicha del adivinador con semillas wil'ka (Piptadenia colubrina) que provocaban alucinaciones o le hacían perder el sentido común. Rowe (1946: 292) avanza que no

(27) Este plazo de un año también fue obligatorio para los visitantes del Coricancha en el Cuzco (Guillén Guillén, 1974: 29 ; Hyslop, 1990: 21). Así pues, uno puede con justa razón preguntarse, si se trata realmente de una costumbre local (costeña) que inspiró a los incas o simplemente una costumbre Inca aplicada en los grandes santuarios del Imperio ( $c f$. Bauer \& Stanish, 2001 a propósito del peregrinaje a las islas del Sol y de la Luna del Titicaca). 
sólo los adivinadores, sino también los sacrificadores se emborrachaban así para cumplir con su oficio. La adivinación no fue un fenómeno específico de Pachacamac:

"Cualquier huaca podía dar respuesta a las preguntas, pero había pocos oráculos que tenían un prestigio tal que fueran consultados por personas provenientes de diferentes partes del Imperio. Los más famosos fueron Apo-Rímac ('Señor oráculo’) (...); PacaKamaq (...); Rimaq ('Oráculo’) (...) y Wari (...). La adivinación se practicaba para diagnosticar una enfermedad, determinar la veracidad de una confesión, localizar un bien perdido, identificar a los brujos hostiles, escoger entre varias vías posibles, definir el sacrificio más apropiado para una deidad y, en general, para contestar a todas las preguntas que carecían de respuesta” (Rowe, 1946: 302).

La ubicación exacta del santuario del ídolo no tiene la aprobación de todos los autores que se interesaron por el tema (28). Aunque me inclino personalmente en favor de la plataforma superior del Templo del Sol, repetidos saqueos del edificio, así como de los edificios propuestos por otros autores (el Templo Viejo, el Edificio Pintado) impiden verificar lo que dicen los textos respecto a los modos de consulta y el aspecto del santuario.

\section{RITOS FUNERARIOS Y CULTO A LOS ANCESTROS}

La concepción del más allá y el tratamiento de los difuntos en las sociedades andinas se diferenciaban radicalmente de las de los conquistadores y una de las tareas principales de los extirpadores consistía en desalojar y destruir las momias y todo lo que tenían asociado (Arriaga, 1999[1621]; Duviols, 1986). En las zonas donde la colonia estuvo bien implantada, por ejemplo la comarca de Lima, la evangelización forzada de la población indígena se acompañaba de una obligación de cambio profundo de las costumbres funerarias con el fin de conformarse con las reglas y tradiciones de la iglesia católica. Aunque este cambio no se hizo sin que se encontrara alguna resistencia (Duviols, 1986), resulta sin embargo, que los ritos funerarios tradicionales cayeron muy rápidamente en desuso —en todo caso, oficialmente- y que muy pocos testimonios se recogieron al respecto. Hasta cuando se trata de autores cuya fiabilidad es ampliamente admitida, Kaulicke (1997: 8) advierte con razón:

"Como otros autores, Cieza de León sintetiza al recurrir a testimonios de los Andes septentrionales para explicar conceptos del área centroandina. Su uso del pretérito al referirse a costumbres pasadas no solamente indica que carece de testimonios directos sino podría referirse a una interpretación de lo hallado en los saqueos sistemáticos de contextos funerarios preincaicos de la costa".

En base a las fuentes de primera mano, parece que se pueden distinguir dos categorías de difuntos: los visibles y los invisibles - es decir, aquellos cuya momia estuvo accesible (permamente u ocasionalmente) y los otros (Arriaga, 1999[1621]: 34-35, 66-67, 76; Avila, 1980[1608?]: 185; Polia, 1999: 121, 235, 296)—. Los difuntos visibles pertenecían a la clase de los ancestros importantes y los señores. Así por ejemplo:

"El sepulcro de los grandes señores era como una casa de habitación, con su sala, cámara y recámara, con todos los demás lugares necesarios para la despensa, cocina, patios,

(28) Para un resumen del tema ver Eeckhout, 1998b; Franco, 1993a. 
corredores, portadas, etc. Muerto el rey o señor (...) metían el difuncto en la recámara o aposento, que estaba para ello aparejado y sentábanlo allí y tapiaban la puerta y ventanas, y en la anterecámara le ponían todos sus tesoros y vajillas y ropa y ofrecían mucha comida, como pan y vino hecho de grano de maíz (...). Luego, como morían [sus descendientes] los metían embalsamados en la antecámara, si era varón, y en el aposento del tesoro, si era mujer (...). Estos sepulcros o huacas estuvieron mucho tiempo patentes, excepto los aposentos donde estaban los difuntos y los tesoros, que tenían tapiadas las puertas y las ventanas, empero los atrios portales, alas y otras piezas estaban abiertas, para que entrasen a rogar a los dioses por aquellos difuntos y a guardarlos por sus tandas y tareas" (Valera, 1968[1585-1589]: 158-159).

Cobo, quizás inspirandose en Cieza de León, (1995[1551], I, cap. 63: 197-198) presenta una variante sobre el mismo tema, que sugiere un entierro:

“(...) y si era señor calificado, mataban algunas de sus mujeres y criados, y otros metían vivos en la sepultura con el muerto, para que le fuesen a servir y acompañar en la otra vida; y vestido y adornado de las ropas y joyas más ricas que tenía, lo sepultaban, poniendo junto a él otras vestiduras nuevas dobladas, mucha comida y bebida, y enterraban juntamente sus armas e instrumentos de su arte y oficio, todas sus riquezas y cosas preciosas. Solían ponerles plata y oro en la boca, en las manos y en el seno, o en otras partes. Celebraban sus aniversarios acudiendo a ciertos tiempos a las sepulturas, y abriéndolas, renovaban la ropa y comida que en ellas habían puesto, y ofrecían algunos sacrificios" (Cobo, 1964[1653]: L. 14, cap. 19: 274).

Se cambiaban, pues, regularmente los vestidos de las momias de esta categoría (Polia, 1999: 121), y se les ofrecía comida, como si estuvieran vivas (Arriaga, 1999[1621]: 34-35, 66-67, 76; Avila, 1980[1608?]: 185; Polia, 1999: 121-123).

Para la otra categoría, la del común, las cosas están menos claras, pues parece que existieron diferencias notables entre las prácticas funerarias de los llanos y de la sierra. En efecto, en la sierra de Cajatambo por ejemplo, los mallquis o munaos se colocaban en cavernas o cuevas (machay) y quedaban entonces de cierta manera siempre accesibles (Duviols, 1986). Juzgando por las descripciones de extirpadores, fue igual en Huarochirí y la sierra de Lima (Arriaga, 1999[1621]: 34-35, 66-67, 76; Avila, 1980[1608?]: 185). En cuanto a la franja costeña desértica y los llanos, Cobo explica que entre las ruinas de Surco (Armatambo), Maranga, y otros asentamientos del valle de Rímac, se encontraban tumbas costeñas típicas que él describe de la siguiente manera:

"Labraban estos sepulcros de paredes de tierra muy gruesas y altas, de la misma traza y forma que las casas principales de sus caciques, puestas en cuadro y con muchas divisiones y apartamientos; algunas tenían las paredes muy juntas en forma de angostos callejones; porque dentro de un cuadro de las dichas paredes hacían otro de la misma forma e igual espacio por todas partes, que parece debían de hacer estos callejones para poderlos fácilmente cubrir con losas atravesadas de una pared a otra. Estas grandes guacas y sepulturas de los Llanos, aunque eran huecas, están hoy cegadas y llenas de tierra, y aún cubiertas algunas de grandes montones de piedra menuda, que como iban enterrando en ellas sus difuntos, las iban terrapenando, según vemos en muchas que han desbaratado y deshecho los vecinos desta ciudad, para aprovecharse de la tierra, haciendo ella adobes para sus fábricas, y aún para buscar tesoros" (Cobo 1964[1653]: L. 14, cap. 18: 272; 1990[1653], cap. 18: 246 \& ss.). 
Según Cieza de León (1995[1653], I, cap. 63: 197):

"En muchos valles de estos llanos, en saliendo del valle por las sierras de rocas y de arena hay hechas grandes paredes y apartamientos, adonde cada linaje tiene su lugar establecido para enterrar sus difuntos: y para ello han hecho grandes huecos y concavidades cerradas con sus puertas lo más primeramente que ellos pueden (...)”.

Entre el ajuar funerario, Cobo menciona respecto a tumbas que él mismo abrió, pequeñas calabazas, cerámicas y mazorcas de maíz perfectamente conservadas (Cobo, 1964: L. 14, cap. 18: 273; 1990, cap. 18: 248 y ss.). Cieza de León (1995[1653], I, cap. 72: 215) precisa que en Pachacamac en los primeros tiempos de la conquista "sacaron gran suma de oro y plata de los enterramientos".

En el marco de un ensayo como este, obviamente es imposible dedicarse a la revisión sistemática de todos los contextos funerarios documentados en el área de estudio (Bourget, 1990; Cornejo, 1999; Eeckhout, 1999b; Farfán, 2000; Franco, 1998; Herrman \& Meyer, 1993; Jijón y Caamaño, 1949; Kaulicke, 1983; 1996; 1997; Machacuay \& Aramburú Casas, 1998; Ravines, 1981; Ühle, 1903; Valladolid, 2000; e.o.).

Las excavaciones llevadas a cabo en el cementerio de Pampa de las Flores (Eeckhout, 1999a) demuestran que las prácticas funerarias ychsma del periodo Intermedio Tardío son similares a las descritas en otras zonas y sitios de la costa central en el mismo periodo. Por lo menos es el caso de los entierros comunes, donde el difunto enfardelado en posición fetal en una serie de textiles y capas de algodón crudo formando un bulto bastante voluminoso está dispuesto verticalmente dentro de una fosa, acompañado por un ajuar más o menos abundante y diversificado. En aquél caso el culto a los muertos se limita — según las evidencias — a visitas puntuales del cementerio por parte de los allegados, quienes realizan ritos conmemorativos incluyendo el consumo de alimentos procesados (29).

El caso de las elites es bastante diferente, pues las prácticas funerarias toman una dimensión especial que tiene repercusiones hasta en la arquitectura y el crecimiento de los asentamientos. En efecto, las investigaciones llevadas a cabo en el Lurín ponen en evidencia un proceso de crecimiento generacional: a la muerte del curaca, su residencia le sirve de sepulcro y sus accesos son ritualmente cerrados, excepto una parte — generalmente un patio o una sala grande — reservada a los ritos conmemorativos y a la consulta entre los vivos y el ancestro que se ha vuelto huaca. El sucesor del curaca construye su residencia al lado o encima de la del jefe difunto (Eeckhout, 1999a; 1999-2000; Feltham, 1983). Así, al proceso de crecimiento “clásico" de un asentamiento - es decir, la edificación de nuevas estructuras siguiendo las necesidades materiales concretas (por ejemplo, el crecimiento de la población, las necesidades de defensa o el aumento de las capacidades de almacenamiento) — se agrega este factor particular, íntimamente ligado a las tradiciones locales. Es interesante subrayar el paralelo entre esta práctica y la que se puso en evidencia para las pirámides con rampa de Pachacamac, las que parecen también haber sido construidas sucesivamente en función de los mismos criterios.

(29) Ver al respecto Arriaga, 1920[1621]: 14, 25, 61; Cobo, 1990[1653], I, cap. 10: 39-43; Salomon, 1995. 


\section{RESUMEN Y CONCLUSIONES}

Creador y oráculo, señor de los orígenes y del destino, Ychsma fue incontestablemente una divinidad regional importante durante el periodo Intermedio Tardío. Cuando los incas le re-bautizan Pachacamac, "el que anima al mundo"; y que el emplazamiento del santuario se designa como el valle de Lurín (sea literalmente el valle "de abajo"), integran la cosmología regional a su propia cosmología. YchsmaPachacamac se vuelve el equivalente costeño de Viracocha, divinidad creadora de los incas serranos. También introducen en los relatos míticos locales la figura dominante del sol. No obstante estas modificaciones, una estructura recurrente sobresale de los mitos estudiados. Más allá de los detalles de la narración, sólo dos historias son contadas. El estudio de las figuras y elementos asociados con la divinidad principal permite poner en evidencia un orden estructural que abarca el orden social, el paisaje, los fenómenos naturales y los actores míticos. Así, el dios Ychsma-Pachacamac, a veces presentado como la divinidad Huallallo Carhuincho, tiene aspectos costeños, terrestres, lunares, femeninos y nocturnos; está asociado al lado hurin (“abajo") y a la zorra. El zorrillo y los peces también pertenecen al grupo estructural costeño. Al contrario, el dios Pariacaca, jefe del panteón de la sierra central, muestra aspectos serranos ígneos, solares, masculinos y diurnos, y está ligado al lado hanan ("arriba"), al puma y al cóndor. El agua y el cielo constituyen elementos mediadores entre ambos grupos, así como las aves. Se revelan en los mitos, en los ritos, en las supersticiones y las maneras de pensar del otro múltiples indicios de esta oposición costa-sierra: le da sentido al mundo. El sentimiento religioso impregna profundamente estas sociedades tradicionales donde las manifestaciones de lo sagrado ayudan a fertilizar los campos, a hacer llover, a crear los canales de irrigación, a ganar territorios, a vencer a los enemigos, etc.

Por lo que concierne a los rituales, disponemos de dos fuentes de información que a veces coinciden: los vestigios materiales hallados en contexto arqueológico y los testimonios escritos que emanan de los que los realizaron o los que asistieron a estos ritos en la época de la conquista.

Al respecto es obligatoria una apreciación que afecta justamente al crédito que se tiene que dar a las fuentes escritas para explicar los vestigios antiguos. Efectivamente, hemos visto que la naturaleza de las ofrendas es la misma sea cual fuere el periodo. En otros términos, son siempre las mismas cosas las que se ofrecen, generación tras generación. Esta recurrencia de objetos no implica necesariamente una igualdad de objetivos: por más que se hallan camélidos ritualmente quemados en el periodo Intermedio Temprano, el sentido profundo del sacrificio puede ser diferente de la ceremonia, aparentemente idéntica, relatada por algún cronista respecto al Pachacamac de los incas - ceremonia que por otro lado dejaría las mismas evidencias en el registro arqueológico- Como lo expliqué anteriormente, he intentado evitar ese tipo de simplificación abusiva, restringiendo al nivel regional las comparaciones de la evidencia escrita tanto como de la arqueológica. A esta restricción espacial se le debe agregar la restricción temporal. Lógicamente es plausible que cuanto más cercano en el tiempo está un contexto de las descripciones escritas, más posibilidades hay de que ambos se aclaren mutuamente. Por lo tanto, no se puede negar que la recurrencia diacrónica de los objetos y prácticas rituales sea una realidad. Lo repito, esto no significa que los rituales no cambiaron ni evolucionaron (su sentido profundo sin duda se escapará para siempre) sino más bien que existen ciertas categorías de objetos que constituyen soportes 
buenos para pensar. Objetivamente es en ellos donde se puede descubrir una continuidad, tal vez hasta una cierta forma de perpetuidad.

Pienso que el vínculo entre mitos y ritos se evidenció claramente en el curso de esta exposición. Los relatos míticos, particularmente los que se refieren a la creación del universo y de la humanidad, hacen explícitos y justifican los sacrificios y las ofrendas. Las asociaciones estructurales puestas en evidencia en el análisis de los mitos aclaran las modalidades de ciertas prácticas rituales. El sacrificio humano afectaba ante todo a los niños quienes, según las evidencias, se enterraban vivos (Pachacamac está asociado con la tierra) a veces desmembrados ( $c f$. el mito de Pachacamac y Vichama). Se conocen algunos casos de adultos que sufrieron el mismo destino. Las víctimas, por lo que he podido juzgar, sirvieron de acompañantes en los ritos funerarios o como ofrendas conmemorando la fundación de edificios importantes. Camélidos también se sacrificaron, frecuentemente desmembrados o quemados, en este caso la mayoría de las veces relacionados a las ceremonias funerarias. El sacrificio más frecuente fue de cuyes, practicado de diversas maneras en un sinnúmero de circunstancias. Los espondylus, las semillas de ishpingo y las hojas de coca representan las ofrendas más corrientes. Paradójicamente, sin embargo, ni los camélidos, ni los cuyes, ni los espondylus, ni las semillas de ishpingo o las hojas de coca se cargan de connotaciones simbólicas, es decir, que no intervienen —o lo hacen apenas - en los relatos que cuentan la creación o las hazañas de los dioses y ancestros. En cuanto si existe un mito de origen de los peces y del océano (Avila, 1980[1608?]) o un mito de origen de las plantas útiles (el de Pachacamac y Vichama), no tenemos nada semejante para los objetos de sacrificios y ofrendas más recurrentes. Esta aparente disyunción merecería una reflexión que sobrepasa el marco del presente ensayo.

El peregrinaje en Pachacamac, cuya importancia interregional es atestiguada en la época de la conquista, tenía sin duda un carácter más local antes de la incorporación en el Imperio Inca. La supuesta "red" conformada por las huacas emparentadas con Ychsma, diseminadas en la comarca, no parece haber tenido implicación particular a nivel político o económico, por lo menos en el periodo Intermedio Tardío.

La adivinación se practicaba ampliamente en los Andes prehispánicos y el oráculo de Ychsma-Pachacamac constituye un ejemplo perfecto al respecto. Consultado por medio de oficiantes que adoptaban para este fin un estado alterado de conciencia gracias a la ingestión de sustancias psicotrópicas, la huaca — cuidadosamente escondida a la mirada profana - probablemente se encarnaba en un objeto semejante al ídolo de madera, encontrado en las excavaciones al pie del Edificio Pintado ( $c f$. Eeckhout, 1999a: 87-90).

El examen de las prácticas rituales regionales pre-incas indica que el culto a los ancestros es el único campo donde lo sociopolítico y lo religioso se juntan directamente y pueden observarse de manera concreta en los vestigios arqueológicos. Es lo que llamé el proceso de crecimiento generacional según el cual, a su muerte, un dirigente es enterrado en su residencia, la cual es entonces abandonada ritualmente, mientras el sucesor del jefe difunto hace construir su propia casa de función. Este principio se aplica desde los pequeños asentamientos de elite del interior hasta los sitios mayores, tal y como lo ilustran los palacios que son las pirámides con rampa de Pachacamac y algunos otros sitios del Lurín.

Existe una serie de elementos y contextos arqueológicos que no encuentran ningún paralelo en los textos conocidos hasta ahora. ¿Qué podemos deducir al respecto? 
Primero, ciertas prácticas pudieron simplemente desaparecer tras la conquista inca o, posteriormente, tras la conquista española. Pudieron pasar desapercibidas a los extirpadores de idolatrías, o tal vez estos no juzgaron útil relatarlas. En relación a ello pienso, por ejemplo, en el uso funerario de las semillas de ishpingo. También se puede pensar que ciertos ritos secretos, quizás conocidos sólo por unos iniciados, no se divulgaron y tanto su realización como su significado se perdieron. Probablemente es el caso de la mayoría de las ofrendas sacadas a la luz en el Templo del Mono en Pachacamac.

Vemos que el culto de Ychsma, así como las creencias y prácticas simbólicoreligiosas en la zona durante el periodo pre-Inca sólo se conocen muy parcialmente y numerosos elementos propuestos aquí como hipótesis necesitan ser verificados. No está de más recomendar la prudencia y el ejercicio del sentido crítico en el exámen de las fuentes escritas de la época de la conquista. Hemos visto que una lectura superficial podría llevar a confusiones, tanto a nivel de los mitos — con la "solarización" impuesta por los incas - como a nivel de los rituales - la problemática del peregrinaje y de la "red" religiosa de las huacas regionales-. Para los restos materiales de actividades de índole ritual es esencial afrontar el registro arqueológico con la mayor minucia. Son los detalles los que permiten a menudo entender el significado de tal ofrenda o las relaciones que pueden existir entre varios contextos aparentemente distintos.

Los fenómenos religiosos prehispánicos de los cuales la arqueología andina proporciona numerosos testimonios son muchas veces explicados tomando como ejemplo la proyección del culto de Ychsma-Pachacamac. El entendimiento de este último, en todos sus detalles, presenta pues una importancia obvia. Sería deseable que las investigaciones en curso, tanto en etnohistoria como en arqueología, ayudaran a aclarar este aspecto esencial de la prehistoria peruana.

\section{Agradecimientos}

Agradezco al INC por haber otorgado los permisos respectivos. La financiación del proyecto Ychsma se aseguró gracias a fondos proporcionados por la Facultad de Filosofía y Letras de la ULB, el Fonds de la Recherche Fondamentale Collective (Bélgica), el Fonds National de la Recherche Scientifique (Bélgica), así como a una Research Grant (\#6676-99) del Comittee for Research and Exploration of the National Geographic Society (Washington). Quisiera agradecer especialmente a Steve Bourget, Michel Graulich y Peter Kaulicke por sus sugerencias y comentarios, así como a María Jesús Jiménez Díaz, Giuliana Mansilla y Luis Andrade Ciudad por haber revisado la traducción del presente ensayo. Asumo la total responsabilidad del contenido, así como de los errores que podrían subsistir. 


\section{Referencias citadas}

ACOSTA, J. de, 1979[1589] - Histoire naturelle et morale des Indes occidentales, 405 p.; Paris: Payot, Bibliothèque Historique (J. Rémy-Zéphyr trad.).

ALBORNOZ, C. de, 1967 [fin del siglo XVI] - La Instrucción para Descubrir Todas las Guacas del Piru y sus Camayos y Haziendas (Ver Duviols, 1967).

ALAPERRINE-BOUYER, M., 1987 - Des Femmes dans le Manuscrit de Huarochirí. Bulletin de l'Institut Français d'Études Andines, 16(3-4): 97-101.

ALVA ALVA, W., 1999 - Sipán. Descubrimiento e investigación, 223 p.; Lima: Ed. Cervecería Backus y Johnston S.A. Colección Culturas y arte del Antiguo Perú.

ALVA ALVA, W. \& DONNAN, C., 1993 - Royal Tombs of Sipan, 230 p.; LosAngeles: Fowler Museum of Cultural History, University of California, Los Angeles.

ARRIAGA, P. J. de, 1920[1621] - La Extirpación de la Idolatría en el Perú. In: Colección de Libros y Documentos Referentes a la Historia del Perú, Tomo I (2 $2^{a}$ Serie), 134 p.; Lima: Sanmarti y Ca.

ARRIAGA, P. J. de, 1999[1621] - La Extirpación de la Idolatría en el Pirú, 200 p Cuzco: Centro de Estudios Rurales Andinos "Bartolomé de las Casas". Estudio preliminar y notas de Henrique Urbano. Monumenta Idolátrica Andina, 3.

AVILA, F. de, 1980[1608?] - Rites et Traditions de Huarochirí, 243 p.; Paris: LHarmattan.Texto quechua traducido por Gerald Taylor.

BAESSLER, A., 1902-1903 - Altperuanische Kunst. Beitrage zur Archaeologie des Inca-Reichs; Berlin (4 Vols).

BAUER, B. S. \& DEARBORN, D., 1995 - Astronomy and Empire in the Ancient Andes. The Cultural Origins of Inca Sky Watching; Austin: University of Texas Press.

BAUER, B. S. \& STANISH, C., 2001 - Ritual and Pilgrimage in the Ancient Andes. The Island of the Sun and the Moon, 314 p.Austin: University of Texas Press.

BÉAREZ, P., GORRITI, M. \& EECKHOUT, P., 2003 - Primeras observaciones sobre uso de invertebrados y peces marinos en Pachacamac en el siglo XV (periodo Intermedio Tardío). Bulletin de l'Institut Français d'Études Andines, 32(1): 51-68.

BENSON, E. P., 1991 - The Chtonic Canine. Latin American Indian Literatures Journal, 7 (1): 95-120.

BENSON, E. P. \& COOK, A. (eds), 2001 - Ritual Sacrifice in Ancient Peru, 211 p.Austin: University of Texas Press.

BOURGET, S., 1990 - Un trousseau pour l'éternité: déballage d'un fardo funéraire péruvien. Recherches Amérindiennes au Québec, 20 (1): 76-83.

BOURGET, S., 1997 - Las Excavaciones en la Plaza 3A de la Huaca de la Luna. In: Investigaciones en la Huaca de la Luna 1995 (Uceda, S., Mujica, E. \& Morales,R., eds.): 51-59; Trujillo: Facultad de Ciencias Sociales, Universidad Nacional de La Libertad.

BOURGET, S., 1998 - Pratiques sacrificielles au site Moche de la Huaca de la Luna. Bulletin de l'Institut Français d'Études Andines, 27(1): 41-74.

BOURGET, S., 2001a - Rituals of Sacrifice: Its Practice at Huaca de la Luna and Its Representation in Moche Iconography. In: Moche Art and Archaeology in Ancient Peru (Pillsbury, J. ed.): 89-110; Washington: Studies in History of Art, 63: National Gallery of Art.

BOURGET, S., 2001b - Children and Ancestors: Ritual Practices at the Site of Huaca de la Luna, North Coast of Peru. In: Ritual Sacrifice in Ancient Peru (Benson, E. \& Cook, A., eds.): 93-118; Austin: University of Texas Press.

BOURGET, S. \& MILLAIRE, J.-F., 2000 - Las Excavaciones en la Plaza 3A y la Plataforma II de la Huaca de la Luna. In: Investigaciones en la Huaca de la Luna 1997 (Uceda, S., Mujica, E. \& Morales, R., eds.): 47-60; Trujillo: Facultad de Ciencias Sociales, Universidad de la Libertad.

BRAY, W., 1990 - Le travail du métal dans le Pérou préhispanique. In: Inca-Peru. 3000 Ans d'Histoire: 292-315; Gand: Imschoot Uitgevers. Catálogo de la exposición presentada a los Musées Royaux d'Art et d'Histoire de Bruxelles. 
BUENO MENDOZA, A., 1982 - El Antiguo Valle de Pachacamac: Espacio, Tiempo y Cultura, 52 p.; Lima: Editorial Los Pinos.

CALANCHA, A. de, 1975[1638] - Crónica Moralizada del Orden de San Agustín en el Perú, con Sucesos Ejemplares Vistos en este Monarquía. Crónicas del Perú, Lima: Edición Ignacio Prado Pastor, Vol. 4, 5, 6.

CIEZA DE LEÓN, P., 1995[1551] - La Crónica del Perú, 354 p.; Lima: Pontificia Universidad Católica del Perú.

COBO, F. B., 1964[1653] - Historia del Nuevo Mundo, T. 41-42; Madrid: Ediciones Atlas, Bibilioteca de Autores Españoles.

COBO, F. B.,1990[1653] - Inca Religion and Customs, 279 p.Austin: University of Texas Press. Traducido y editado por R. Hamilton.

CORNEJO GUERRERO, M., 1999 - An Archaeological Analysis of an Inka Province: Pachacamac and the Ishma Nation of the Central Coast of Peru, 469 p.; Unpublished Ph.D. Thesis, Australian National University, Camberra.

CORDY-COLLINS, A., 1990 - Fonga Sidge, Shell Purveyor to the Chimu Kings. In: The Northern Dynasties. Kingship and Statecraft in Chimor (Moseley, M. E. \& Cordy-Collins, A., eds.): 393-418; Washington: Dumbarton Oaks Research Library and Collection.

CORDY-COLLINS, A., 2001a - Decapitation in Cupisnique and Early Moche Societies In: Ritual Sacrifice in Ancient Peru (Benson, E. \& Cook, A., eds.): 21-33; Austin: University of Texas Press.

CORDY-COLLINS, A., 2001b - Blood and the Moon Priestesses: Spondylus Shells in Moche Ceremony. In: Ritual Sacrifice in Ancient Peru (Benson, E. \& Cook, A., eds.): 34-54; Austin: University of Texas Press.

DAVIDSON, J., 1981 - ElSpondylus en la cosmología chimú. Revista del Museo Nacional, XLV: 75-88.

DÁVILA BRIZEÑO, D., 1881[1586] - Descripción y relación de la provincia de los Yauyos toda, Anan Yauyos y Lorin Yauyos. In: Relaciones Geográficas de India (Jimenez de la Espada, M., ed.): 155-65; Madrid: Biblioteca de Autores Españoles, T. 188.

DEMAREST, A. A., 1981 - Viracocha. The Nature and Antiquity of the Andean High God. Peabody Museum Monographs, 6: 88 p.; Cambridge: Harvard University

DUVIOLS, P., 1967 - Un Inédito de Cristobal deAlbornoz: La Instrucción para Descubrir Todas las Guacas del Piru y sus Camayos y Haziendas. Journal de la Société des Américanistes, 56 (1): 7-39.

DUVIOLS, P., 1973 - Huari y Llacuaz. Agricultores y pastores. Un dualismo pre-hispánico de oposición y complementariedad. Revista del Museo Nacional, 39: 153-191.

DUVIOLS, P., 1979 - Un symbolisme de l'occupation, de l'aménagement et de l'exploitation de l'espace. Le monolithe "huanca" et sa fonction dans les Andes pré-hispaniques. L'Homme, 19 (2): 7-31.

DUVIOLS, P., 1983 - El Contra idolatriam de Luis de Teruel y una versión primeriza del mito de Pachacamac-Vichama. Revista Andina, 1 (2): 385-392; Cuzco.

DUVIOLS, P., 1986 - Cultura Andina y Represión. Procesos y visitas de idolatrías y hechicerías, Cajatambo, siglo XVII, 570p.; Cuzco: Centro de Estudios Rurales Andinos "Bartolomé de las Casas". Archivos de Historia Andina, 5.

EECKHOUT, P., 1993 - Le Créateur et le Devin. À propos de Pachacamac, Dieu Précolombien de la Côte Centrale du Pérou. Revista Española de Antropología Americana, 23: 135152.

EECKHOUT, P., 1995 - Pirámide con Rampa n ${ }^{\circ}$, Pachacamac. Resultados Preliminares de la Primera Temporada de Excavaciones (Zonas 1 \& 2). Bulletin de l'Institut Français d'Études Andines, 24(2): 102-156.

EECKHOUT, P., 1998a - La renarde yunga: une figure symbolique préhispanique. Revista Española de Antropología Americana, 28: 119-149.

EECKHOUT, P., 1998b - Le Temple de Pachacamac sous l'Empire inca. Journal de la Société des Américanistes, 84 (1): 9-44. 
EECKHOUT, P., 1998c - Offrandes funéraires à Pachacamac et Pampa de las Flores. Exemples des relations entre les côtes nord et centrale du Pérou à l'époque pré-inca. Baessler Archiv Neue Folge, 46: 165-229.

EECKHOUT, P., 1999a - Pachacamac durant l'Intermédiaire récent. Étude d'un site monumental préhispanique de la Côte centrale du Pérou, 504 p.; Oxford: BritishArchaeological Reports International Series, 747. Hadrian Books Ltd.

EECKHOUT, P., 1999b - Les sacrifiés de Pampa de las Flores. Contribution archéologique à l'étude du sacrifice humain dans les Andes préhispaniques. Recherches Amérindiennes au Québec, 29: 18-50.

EECKHOUT, P., 1999c - Pirámide con rampa $n^{\circ}$ III, Pachacamac. Nuevos datos, nuevas perspectivas. Bulletin de l'Institut Français d'Études Andines, 28(2): 169-214.

EECKHOUT, P., 1999-2000 - The Palaces of the Lords of Ychsma. An Archaeological Reappraisal of the Function of Pyramids with Ramps at Pachacamac, Central Coast of Peru. Journal of American Archaeology, 17-18-19: 217-254.

EECKHOUT, P., 2001 - Semillas sagradas: el ishpingo (Nectandra sp.) en Pachacamac, costa central del Perú; Belgique: Comunicación presentada en el XIV Congreso de la Union Internationale des Sciences Pré- et Protohistoriques.

EECKHOUT, P., 2002a - Hallazgo y desenfardelamiento de un bulto funerario de Pachacamac. In: Actas de las II Jornadas Internacionales sobre textiles precolombinos: 135-152; Departament d'Art, Universitat Autônoma de Barcelona. (Victôria Solanilla Demestre, ed.).

EECKHOUT, P., 2002b - A View From the Central Coast: Incas and Chimus at Pachacamac. Norwich, Anglia: University of East. Presentación del Seventh Annual Saintsbury Research Seminar: The Inca and Chimor: Imperial Strategies on the Late Prehispanic North Coast of Peru.

EECKHOUT, P., 2003 - Diseño arquitectónico, patrones de ocupación y formas de poder en Pachacamac, Costa central del Perú. Revista Española de Antropología Americana, 33: 17-37.

EECKHOUT, P., 2004 (en prensa) - El Santuario del Oráculo de Pachacamac y los Peregrinajes a Larga Escala en los Andes Prehispánicos. In: Adivinación y Oráculos en las Américas (Curatola Petrocchi, M. ed.), Lima: Pontificia Universidad Católica del Perú, Fondo Editorial.

EECKHOUT, P. \& FARFÁN LOVATON, C., 2000 - Proyecto Ychsma. Investigaciones Arqueológicas y Estudios de Restauraciones en el Sitio de Pachacamac, Primera temporada (1999), 221 p.; Lima: Informe final para el Instituto Nacional de Cultura.

EECKHOUT, P. \& FARFÁN LOVATON, C., 2001 - Proyecto Ychsma. Investigaciones Arqueológicas y Estudios de Restauraciones en el Sitio de Pachacamac, Segunda temporada (2000), 204 p.; Lima: Informe final para el Instituto Nacional de Cultura.

ESPEJO NÚÑEZ, J., 1941 - Cuentos, Leyendas y Anecdotas Relacionadas con las Ruinas de Pachacamac. Chaski, 1 (3): 66-71.

ESPINOZA SORIANO, W., 1984 - Los señoríos de Yaucha y Picoy en el abra del medio y alto Rimac, siglos XV-XVI. Revista Histórica, Academia Nacional de la Historia de Lima, 34: 157-279.

FARFÁN LOVATON, C., 2000 - Informe sobre entierros prehispánicos en Huaquerones, Valle del Rímac. Arqueologicas, 24: 275-302.

FAVRE. H., 1972 - Les Incas, 126 p.; Paris: PUFCollection Que sais-je ?

FELTHAM, J. P., 1983 - The Lurin Valley, Peru: AD1000-1532; Ph. D. Diss. Institute of Archaeology, University of London, 1097 p.

FELTHAM, J. P., 1984 - The Lurin Valley Project - Some Results for the Late Intermediate and Late Horizon Periods. In: Current Archaeological Projects in the Andes: Some Approaches and Results (ed. A. Kendall): 45-73; Oxford: British Research Council International Series, 210.

FELTHAM, J. P., 2002 - Tejidos de los periodos tardíos de Pachacamac, Costa Central del Perú. In: Actas de las II Jornadas Internacionales sobre textiles precolombinos (Victória Solanilla Demestre ed.): 95-114. Departamento de Arte, Universidad Autónoma de Barcelona. 
FLEMING, S., 1983 - Infant Sacrifice at Pachacamac, Peru: Dignity in Death. Archaeology, 40 (2): 64-65, 74, 77.

FLEMING, S., 1986 - The Mummies of Pachacamac. An Excepcional Legacy's from Ühle's 1896. Excavations in Peru. Expedition, 28 (3): 39-45.

FLEMING, S., MILLER, W. T. \& BRAHIN, J. L., 1983 - The Mummies of Pachacamac, Peru. Masca Journal, Suplemento de Pachacamac, 2(5): 137-159; Philadelphie: University of Pennsylvania.

FRANCO JORDÁN, R., 1993a - Los dos templos principales de Pachacamac. Breve síntesis. Revista del Museo de Arqueología, 4: 55-77; Trujillo: Universidad Nacional de Trujillo, Facultad de Ciencias Sociales.

FRANCO JORDÁN, R., 1993b - El centro ceremonial de Pachacamac: nuevas evidencias en el Templo Viejo. Boletín de Lima, 86: 45-62.

FRANCO JORDÁN, R., 1998 - La Pirámide con Rampa $n^{\circ} 2$ de Pachacamac. Excavaciones y Nuevas Interpretaciones, 105p; Trujillo.

FRANCO JORDÁN, R. \& PAREDES BOTONI, P., 2000 - El Templo Viejo de Pachacamac: nuevos aportes al estudio del Horizonte Medio. Boletín de Arqueología PUCP, 4: 607-630.

GARCILASO DE LA VEGA, I., 1991[1609] - Comentarios Reales de los Incas, 880 p.; Lima: Fondo de Cultura Económica. 2 volúmenes.

GISBERT, T., 1993 - Pachacamac y los dioses del Collao. In: Religions des Andes et langues indigènes. Equateur - Pérou - Bolivie. Avant et après la conquête espagnole, Actes du Colloque III d'études andines (Duviols, P., ed.): 182-202; Aix-en-Provence: Publications de l'Université de Provence.

GONZALEZ HOLGUIN, D., 1989[1608] - Vocabulario de la Lengua General de Todo el Perú Llamada Lengua Quichua o del Inca, 707 p.; Lima: Editorial de la Universidad Nacional Mayor de San Marcos.

GUAMAN POMA DE AYALA, F., 1989[1613] - Nueva Crónica y Buen Gobierno, 1140 p.; Paris: Trabajos y Memorias del Instituto de Etnología 23. Segunda re-impresión.

GUILLEN GUILLEN, E., 1974 - Versión Inca de la Conquista, 192 p.; Lima: Editorial Milla Batres.

HERNANDEZ PRINCIPE, R., 1919[1622] - Idolatrías de los Indios Huachos y Yauyos. Carta Anual del año 1613 del Colegio de la Compañía de Jesús de Huamanga. Revista Histórica, 6: 180-197; Lima.

HERRMANN, B. \& MEYER, R.-D., 1993 - Südamerikanische Mumien aus vorspanischer Zeit. Eine radiologische Untersuchung, 135 p.:Abteilung Amerikanische Archäeologie, VIII. Berlin:Veräffentlichungen.Veräffentlichungen des Museums für Völkerkunde.

HYSLOP, J., 1990 - Inka Settlement Planning, 377 p.;Austin: University of Texas Press.

JEREZ, F. de, 1965[1534] - Verdadera Relación de la Conquista del Perú llamada la Nueva Castilla Conquistada por Francisco Pizarro. In: Crónicas de la Conquista del Perú (Le Riverend, J., ed.): 29-124; México: Editorial Nueva España S.A.

JIJÓN Y CAAMAÑO, J., 1949 - Maranga, Contribución al Conocimiento de los Aborígenes del Valle del Rímac, Perú, 511 p.; Quito: La Prensa Católica.

JIMÉNEZ BORJA, A., 1985 - Pachacamac. Boletín de Lima, 38: 40-54; Lima.

JIMÉNEZ BORJA, A., 1992 - Las Huacas. Pachacamac, Revista del Museo de la Nación, 1(1): 125-131; Lima.

KAULICKE, P., 1983 - Gräber von Ancón, Peru: Nach den Arbeiten von W. Reiss/A. Stübel, M. Ühle, R. Ravines, G.R. Willey und C. Huapaya. Munich:Verlag C.H. Beck.

KAULICKE, P., 1996 - Contextos funerarios de Ancón. Esbozo de una síntesis analítica, 123 p.; Lima: Pontificia Universidad Católica del Perú. Fondo editorial.

KAULICKE, P., 1997 - La muerte en el Antiguo Perú. Contextos y conceptos funerarios: una introducción. Boletín de Arqueología PUCP, 1: 7-54.

KEATINGE, R. W., 1982 - The Chimu empire in a regional perspective: CulturaAntecedents and Continuities. In: Chan Chan: Andean Desert City (Moseley, M. \& Day, K., eds.): 197-224; Albuquerque: University of New Mexico Press, A School of American Research Book. 
KEMPER COLUMBUS, C., 1992 - Llamastronomers-Eyes-and-Roads: Chaupinamca of Huarochiri. Journal de la Société des Américanistes, 78(1): 31-44.

KRICKEBERG, W., 1971 - Mitos y Leyendas de los Aztecas, Incas, Mayas y Muiscas, 267 p.; México: Fondo de Cultura Económica.

LARA, J., 1978 - Diccionario Qu'shwa-Castellano/Castellano-Qh'shwa, 422 p.; La PazCochabamba: Editorial Los Amigos del Libro.

LEE BRUCE, S., 1986 - The Audiencia Room of the Huaca 1 Complex. In: The Pacatnamu Papers, Volume 1 (Donnan, C. \& Cock, G., eds.): 95-108; Los Angeles: University of California, Museum of Cultural History.

LÓPEZ DE GOMARA, F., 1965[1552] - Historia General de las Indias; Barcelona: Editorial Iberia.

LUMBRERAS, L.,1987-Childe and Urban Revolution: The Andean Experience. In: Studies in the Neolithic and Urban revolutions: The Gordon Childe Colloquium, Mexico 1986(Manzanilla, L., ed.): 327-344; Oxford: British Archaeological Research International Series, 329.

LYON, P., 1995 - Death in the Andes. In: Tombs for the Living: Andean Mortuary Practices (Dillehay, T. D., ed.): 379-390; Washington: Dumbarton Oaks Research Library and Collection.

MACHACUAY, M. A. \& ARAMBURÚ CASAS, R., 1998 - Contextos Funerario\$ardíos en La Salina, Valle de Rímac. Arqueología y Sociedad, 12: 37-50.

MALENGREAU, J., 1995 - Sociétés des Andes. Des empires aux voisinages, 512 p.; Paris: Ediciones Kartala.

MENZEL, D., 1977 - The Archaeology of Ancient Peru and the Work of Max Ühle, 275 p.; Berkeley: University of California, R.H. Lowie Museum of Anthropology.

MÉTRAUX, A., 1949 - Religion and Shamanism. In: Handbook of South American Indians (Vol. V) (Steward, E. H., ed.): 559-599; Washington: Bureau of American Ethnology, Bulletin 143.

MICHZINCKI, A., EECKHOUT, P. \& PAZDUR, A., 2003 - Absolute Chronology of Pyramid III and the Dynastic Model at Pachacamac, Peru. Radiocarbon, 45 (1): 59-74.

MOLINA DE CUZCO, C., 1943[1552] - Relación de las fábulas y ritos de los incas. Colección de libros y documentos referentes a la historia del Peru, T. I.: 1-103; Lima: Sanmarti y Ca.

MONTOYA, M. de, 1996 - Implicancias del estudio de semillas rituales de Nectandra sp. en la época prehispánica. Revista del Museo de Arqueología de la Universidad de Trujillo, 6: 203-215.

MONTOYA, M. de, 1998 - Complejo de ofrendas rituales en el periodo Intermedio Tardío. Revista Arqueológica Sian, 5: 9-12.

MONTOYA, M. de, 1999 - Polvos de espingo. Revista Arqueológica Sian, 9: 5-16.

MORALES, E., 1995 - The Guinea Pig: Healing, Food and Ritual in the Andes, 177 p.Tucson: University of Arizona Press.

MOROTE BEST, E., 1988 - Aldeas sumergidas. Cultura popular y sociedad en los Andes, 366 p.; Cuzco: Centro de estudios rurales andinos Bartolomé de las Casas.

MURRA, J. V., 1975 - Formaciones económicas y políticas del mundo andino, 339 p.; Lima: Instituto de Estudios Peruanos.

NARVÁEZ, A., 1995 - The Pyramids of Tucume. The Monumental Sector. In: Pyramids of Tucume. The Quest for Peru's Forgotten City (Heyerdahl, T., Sandweiss, D. H. \& Narváez, A.): 79-130; Londres: Thames and Hudson.

PAREDES BOTONI, P., 1985 - La Huaca pintada o El Templo de Pachacamac. Boletín del Lima, 41: 70-77

PAREDES BOTONI, P., 1990 - Pachacamac. In: Inca-Peru. 3000 Ans d'Histoire: 178-195; Gand: Imschoot Uitgevers. Catálogo de la exposición presentada a los Musées Royaux d'Art et d'Histoire de Bruxelles.

PAREDES BOTONI, P. \& FRANCO JORDÁN, R., 1989a - Proyecto Templo Viejo de Pachacamac. Primer informe Parcial - Primera temporada de Excavaciones, 78 p.; INCMuseo de Sitio de Pachacamac. 
PAREDES BOTONI, P. \& FRANCO JORDÁN, R., 1989b - Proyecto Templo Viejo de Pachacamac. Segundo informe Parcial - Segunda temporada de Excavaciones, 102 p.; INC- Museo de Sitio de Pachacamac.

PAREDES BOTONI, P. \& RAMOS GIRALDO, J., 1994 - Excavaciones arqueológicas en el sector Las Palmas, Pachacamac. Boletín de Lima, 91-96: 313-349.

PATTERSON, T. C., 1983 - Pachacamac: An Andean Oracle under Inca Rule. In: Recent Studies in Andean Prehistory and Protohistory (Kvietok, P. D. \& Sandweiss, D. H., eds.): 159-176; Ithaca: Cornell University, Latin American Studies Program, Papers frome the Second Annual Northeast Conference on Andean Archaeology and Ethnhohistory.

PATTERSON, T. C., 1992 - The Inca Empire. The Formation and Disintegration of a Precapitalist State, 211 p.; Beg, New York/Oxford.

PAULSEN, A. C., 1974 - The thorny oyster and the voice of God: Spondylus and Strombus in Andean prehistory. American Antiquity, 39: 597-607.

PEASE, F. G.Y., 1973 - El Dios Creador Andino, 149 p.; Lima: MoscaAzul Editores.

PEASE, F. G.Y., 1992 - Perú, hombre e historia II. Entre el siglo XVI y el XVII, 347 p.; Lima: Edubanco.

PILLSBURY, J., 1996 - The Thorny Oyster and the Origins of Empire: Implications of Recently Uncovered Spondylus Imagery from Chan Chan. Latin American Antiquity, 7(4): 313-340.

PIZARRO, H., 1872[1533] - A Letter of Hernando Pizarro to the Royal Audience of Santo Domingo, November 1533. In: Reports on the Discovery of Peru III (Markham, C. R., ed.): 111-127; Londres: Hayklut Society.

PIZARRO, P., 1978[1571] - Relación del Descubrimiento y Conquista de los Reinos del Perú: 277 p.; Lima: Pontificia Universidad Católica del Perú, Fondo editorial.

POLIA MECONI, M., 1999 - La Cosmovisión Religiosa Andina en los documentos inéditos del Archivo Romano de la Compañía de Jesús 1581-1752, 627 p.; Lima: Pontificia Universidad Católica del Perú. Fondo editorial.

POZORSKI, T. G., 1980 - Las Avispas: plataforma funeraria. In: Chan Chan metropoli chimu (Ravines, R., ed.): 231-242; Lima: Instituto de Estudios Peruanos - ITINTEC.

RAVINES, R., 1981 - Prácticas funerarias en Ancón. Revista del Museo Nacional, 45: 89-166.

RAVINES, R., 1990 - Los gallinazos de Pachacamac. Boletín de Lima, 72: 28-30.

REINHARD, J., 1999 - Trois enfants incas figés pour l'éternité. National Geographic (France), 1(2): 42-61.

RIVERO, M. E. de \& TSCHUDI von, J. D., 1851 -Antigüedades Peruanas, 275 p.;Viena: Imprenta Imperial de la Corte y del Estado.

ROSTWOROWSKI de DIEZ CANSECO, M., 1972 - Breve Informe sobre el Señorío de Ychma o Ychima. Arqueología PUC, 13: 37-51; Lima: Pontificia Universidad Católica del Perú, Instituto Riva-Agüero.

ROSTWOROWSKI de DIEZ CANSECO, M., 1977 - Etnia y Sociedad: Ensayos sobre la Costa Central Pre-hispánica, 293 p.; Lima: Instituto de Estudios Peruanos.

ROSTWOROWSKI de DIEZ CANSECO, M., 1978 - Señoríos Indigenas de Lima y Canta. 280 p.; Lima: Instituto de Estudios Peruanos.

ROSTWOROWSKI de DIEZ CANSECO, M., 1981 - Recursos Naturales Renovelables y Pesca, siglos XVI y XVII, 180 p.; Lima: Instituto de Estudios Peruanos.

ROSTWOROWSKI de DIEZ CANSECO, M., 1983 - Estructuras Andinas del Poder, 202 p.; Lima: Instituto de Estudios Peruanos.

ROSTWOROWSKI de DIEZ CANSECO, M., 1989 - Costa Peruana Prehispánica, 318 p.; Lima: Instituto de Estudios Peruanos.

ROSTWOROWSKI de DIEZ CANSECO, M., 1991 - Algunos Mitos Referentes al Dios Pachacamac. In: El Umbral de los Dioses (Lemlij, M. \& Millones, L., eds.): 47-67; Lima: Biblioteca Peruana de Psicoanálisis, 6. SIDEA.

ROSTWOROWSKI de DIEZ CANSECO, M., 1992 - Pachacamac y el Señor de los Milagros. Una Trayectoria Milenaria, 214 p.; Lima: Instituto de Estudios Peruanos. 
ROSTWOROWSKI de DIEZ CANSECO, M., 1993a - Origen Religioso de los Dibujos y Rayas de Nasca. Journal de la Société des Américanistes, 89: 189-202.

ROSTWOROWSKI de DIEZ CANSECO, M., 1993b - Ensayos de Historia Andina. Elites, Etnias, Recursos, 460 p.; Lima: Instituto de Estudios Peruanos.

ROSTWOROWSKI de DIEZ CANSECO, M., 1999a - El Señorío de Pachacamac. El informe de Rodrigo Cantos de Andrade de 1573, 238 p.; Lima: Instituto de Estudios Peruanos.

ROSTWOROWSKI de DIEZ CANSECO, M., 1999b - History of the Inca Realm, 259 p.; Translated by Harry B. Iceland. Cambridge University Press, Cambridge.

ROWE, J. H., 1946 - Inca Culture at the time of the Spanish Conquest. In: Handbook of South American Indians (Vol. II) (Steward, J. H., ed.): 183-330; Washington: Bureau of American Ethnology, Bulletin 143.

SALOMON, F., 1995 - The Beautiful Grandparents: Andean Ancestor Shrines and Mortuary Rituals as Seen Through Colonial Records. In: Tombs for the Living: Andean Mortuary Practices (Dillehay, T. D., ed.): 315-354; Washington: Dumbarton Oaks. Research Library and Collection.

SALOMON, F. \& URIOSTE, G. L. (eds.), 1991 - The Huarochiri Manuscript: a testament of ancient and colonial andean religion, 273p.; Austin: University of Texas Press.

SANCHEZ BORJA, A. E., 2000 - Relaciones sociales serrano costeñas durante el Intermedio Tardío en el valle del río Lurín. Arqueológicas, 24: 127-146.

SANDWEISS, D. H., 1992 - The Archaeology of the Chincha Fishermen: Specialization and Status in Inka Peru. Bulletin of the Carnegie Museum of Natural History, 29: 161.

SANDWEISS, D. H. \& RODRÍGUEZ DE SANDWEISS M. del C., 1991 - Moluscos marinos en la prehistoria peruana: Breve ensayo. Boletín de Lima, 75: 55-63.

SANDWEISS, D. H. \& WING, E. S., 1997 - Ritual Rodents: The Guinea Pigs of Chincha, Peru. Journal of Field Archeology, 24 (1): 47-58.

SANTACRUZ PACHACACUTI YAMQUI SALCAMAYGA, J. de, 1879[1613] - An Account of the Antiquities of Peru. In: Narratives of the Rites and Laws of the Yncas (Markham, C. R., ed. \& trad.): 1-115; Londres: Hayklut Society.

SANTILLAN, H. de, 1879[1551] - Relación del origen, descendencia, política y gobierno de los Incas. In: Tres Relaciones de Antigüedades Peruanas: 15-185; Madrid: Ministerio del Fomento.

SARMIENTO DE GAMBOA, P., 1907[1572] - History of the Incas, 395 p.; Cambridge: Hayklut Society (Markham, C. R. trad. \& ed.).

SHIMADA, I., 1991 - Pachacamac Archaeology. Retrospect and Prospect. In: Pachacamac. A Reprint of the 1903 Edition by Max Ühle, 51 p.; Filadelfia: University of Pennsylvania Press.

SHIMADA, I., 1994 - Pampa Grande and the Mochica Culture, 323 p.Austin: University of Texas Press.

SILVERMAN, H., 1993 - Cahuachi in the Ancient Nasca World, 371 p.; Iowa: University of Iowa Press.

SPALDING, K., 1984 - Huarochiri. Andean Society Under Inca and Spanish Rule, 364 p.; Stanford: University Press.

SUTTER, R. C., 2001 - Reseña de Ritual and Sacrifice in Ancient Peru (editada por Benson, E. P., \& Cook, A.). Nahua Newsletter, 32: 27-33.

TAYLOR, G., 1987 - Ritos y tradiciones de Huarochirí. Manuscrito quechua de comienzos del siglo XVII, 618 p.; Estudio biográfico sobre Francisco deAvila por A. Acosta; Lima: Coedición IFEA-IEP.

TELLO, J. C., 1923a - Wira Kocha. Inca, 1(1): 93-320.

TELLO, J. C., 1923b - Wira Kocha. Inca , 1(3): 583-606.

TICO ETHNOBOTANICAL DICTIONARY: http://www.ars-grin.gov/duke/dictionary/tico/ n.html

TOPIC, J. R., 1982 - Lower-Class Social and Economic Organization at Chan Chan. In: Chan Chan: Andean Desert City (Moseley, M. \& Day, K.C., eds.): 145-176; Albuquerque, University of New Mexico Press, School of American Research Book. 
TOWLE, M., 1961 - The Ethnobotany of Pre-columbian Peru, 180 p.; Chicago:Viking Found Publications in Anthropology 30. Aldine Publishing Co.

TRIMBORN, H., 1953 - El Motivo Explanatorio en los Mitos de Huarochirí. Letras, I: 135146; Lima: Universidad Nacional Mayor de San Marcos.

ÜHLE, M., 1903 - Pachacamac. Report of The William Pepper, M.D., LL.D. Peruvian Expedition of 1896, 103 p.; Filadelfia:The Dpt of Archaeology of the University of Pennsylvania.

URBANO, H., 1981 - Wirakocha y Ayar, héroes y funciones en las sociedades andinas, 185 p.; Cusco: Centro de Estudios Regionales Andinos "Bartolomé de las Casas".

URBANO, H., 1986 - La Invención Andina del Hombre, de la Cultura y de la Sociedad y los Ciclos Míticos Judeocristianos. Boletín de Lima, 46: 51-60.

URBANO, H., 1993 - Introducción al estudio del espacio simbólico andino. In: Mito y simbolismo en los Andes. La figura y la palabra (Urbano, H., ed.): 7-52; Cusco: Centro de Estudios Regionales Andinos "Bartolomé de las Casas", 185 p.

VALERA, B., 1968[1585-1589] - Relación de las Costumbres Antiguas de los Naturales del Piru. In: Crónicas Peruanas de Interés Indígena (Barba, F. E., ed.): 135-203; Madrid: Ediciones Atlas, Biblioteca de Autores Españoles, T. 209.

VALLADOLID, C., 2000 - Proceso de desenfardelamiento del Fardo Funerario n ${ }^{\circ} 22$ de Huallamarca. Arqueológicas, 24: 261-272.

VELASCO, J. de, 1840[s.f.] - Histoire du Royaume de Quito; Paris: Arthus Bertrand LibraireÉditeur (Publicado en francés por Ternaux-Compans, H).

VELASCO DE TORD, E., 1978 - La K'apakocha: Sacrificios Humanos en el Incario. In: Etnohistoria y Antropología Andina, Primera Jornada del Museo Nacional de Historia: 193-199; Lima.

VERANO, J. W., 1995 - Where Do They Rest ? The Treatment of Human Offerings and Trophies inAncient Peru. In: Tombs for the Living: Andean Mortuary Practices (Dillehay, T. D., ed.): 189-228; Washington: Dumbarton Oaks Research Library and Collection.

VERANO, J. W., 1998 - Sacrificios humanos, desmembramientos y modificaciones culturales en restos osteológicos: Evidencias de las temporadas de investigación 1995-1996. In: Investigaciones en la Huaca de la Luna 1996 (Uceda, S., Mujica, E. \& Morales, R., eds.): 159-171; Trujillo: Universidad Nacional de La Libertad, Facultad de Ciencias Sociales.

VERANO, J. W., 2001 - The Physical Evidences of Human Sacrifices in Ancient Peru. In: Ritual Sacrifices in Ancient Peru (Benson, E. \& Cook, A., eds.): 165-184; Austin: Univerity of Texas Press.

VERANO, J. W. \& CORDY-COLLINS, A., 1986 - H1M1: A Late Intermediate Period Mortuary Structure at Pacatnamu. In: The Pacatnamu Papers, Volumen 1 (Donnan, C. B. \& Cock, G., eds.): 85-94; Los Angeles: University of California, Museum of Cultural History.

VILLAR CORDOVA, P. E., 1933 - Folklore de la Provincia de Canta (en el departamento de Lima): El Mito de "Wa-kon y los Willkas" referente al Culto Indígena de la Cordillera de "la Viuda". Revista del Museo Nacional, 2 (3):161-179.

WEBSTER, 2001[1913] - Webster's New Century Dictionary. New York: Gramercy.

ZUIDEMA, T., 1962 - The Relationships between Mountain and Coast in Ancient Peru. The Wonder of Man's Ingenuity. Meddedelingen van Het Rijksmuseum voor Volkenkunde, 15: 156-165; Leyden. 